TITLE:

\title{
Copepoda Associated with the Scleractinian Coral Galaxea in the Indo-Pacific
}

\author{
$\operatorname{AUTHOR}(S)$ :
}

Humes, Arthur G.

\section{CITATION:}

Humes, Arthur G.. Copepoda Associated with the Scleractinian Coral Galaxea in the IndoPacific. PUBLICATIONS OF THE SETO MARINE BIOLOGICAL LABORATORY 1996, 37(1-2): 149

ISSUE DATE:

1996-02-29

URL:

http://hdl.handle.net/2433/176256

RIGHT: 


\title{
Copepoda Associated with the Scleractinian Coral Galaxea in the Indo-Pacific
}

\author{
ARTHur G. Humes \\ Boston University Marine Program, Marine Biological Laboratory, \\ Woods Hole, Massachusetts 02543, U.S.A.
}

\begin{abstract}
Eight copepods associated with the shallow-water, Indo-Pacific coral Galaxea are described: Cyclopoida (Cyclopinidae) - Pterinopsyllus stirpipes, new species; Poecilostomatoida (Anchimolgidae) - Anchimolgus nasutus, new species, $A$. compressus, new species, $A$. moluccanus, new species; Siphonostomatoida (Asterocheridae) - Hetairosyna galaxeae, new species, $H$. wedensis, new species, Hetairosynopsis bucculentus, new genus, new species, and Madacheres serratulus, new genus, new species. Keys to females of Anchimolgus and Hetairosyna and new records for six other previously known copepods from Galaxea are provided. Fifteen species of copepods are now known to be associated with Galaxea.
\end{abstract}

Among the many studies of copepods associated with Scleractinia in the Indo-Pacific published during the past few decades, two (Humes 1979, 1985) have dealt with copepods from Galaxea. From Nosy Bé, northwestern Madagascar, Xarifia sp. is known from Galaxea astreata (Lamarck) (see Humes, 1985). At Karang Mie, Halmahera, in the Moluccas, several species have been reported from Galaxea fascicularis (L.) : Xarifa exserens Humes, 1985, is associated with Galaxea fascicularis (L.) (see Humes, 1985). Also from Karang Mie, Humes (1979) reported four species from G. fascicularis: Clamocus spinifer Humes, 1979, Karanges galaxeanus Humes, 1979, Karanges hypsorophus Humes, 1979, and Anchimolgus contractus Humes, 1979. In addition, $A$. contractus is known from $G$. fascicularis at Pulau Naira, Banda Islands, in the Moluccas (Humes, 1979).

In this paper, one new species of Cyclopoida (Cyclopinidae), three new species of Poecilostomatoida [Anchimolgidae; for usage of this family name see Humes \& Boxshall (1996)], and four new species of Siphonostomatoida (Asterocheridae), including two new monotypic genera, are reported from Galaxea. New records for six other copepods from Galaxea are included. Including the species below, there are now 15 species of copepods known to be associated with the Indo-Pacific coral genus Galaxea.

\section{Materials and Methods}

The copepods were collected by the author in 1963-1964, 1967, and 1975. Portions of the colonies of Galaxea were broken off, immediately enclosed in plastic bags in sea water, and transported to the laboratory, where a small amount of $95 \%$ ethanol was added, sufficient to make approximately a $5 \%$ solution. The corals were then soaked for a few hours, vigorously shaken, and the entire wash water passed through a fine net ( 120 holes per $2.5 \mathrm{~cm}$, each hole about $120 \mu \mathrm{m}$ square). The copepods were then recovered from the sediment retained in the net.

The copepods were measured and dissected in lactic acid, using the wooden slide method described by Humes \& Gooding (1964). All figures were drawn with the aid of a camera lucida. The explanation after each figure refers to the scale at which it was drawn. The body length was taken from the anterior end of the cephalosome to the posterior end of the caudal ramus. The segments of the antennule were measured along their posterior nonsetiferous margins. In the formulas for legs 1-4, the Roman numerals indicate spines and the Arabic numerals represent setae. 


\section{Systematics}

Order Cyclopoida Burmeister, 1834

Family Cyclopinidae Sars, 1913

Subfamily Pterinopsyllinae Kiefer, 1929

Genus Pterinopsyllus Brady, 1880

\section{Pterinopsyllus stirpipes, new species}

(Figs. 1-4)

Type material. 7 우우 from Galaxea sp., in $6 \mathrm{~m}$, Nosy N'Tangam, near Nosy Bé, northwestern Madagascar, 24 vi 1967. Holotype (USNM 268445) and 4 paratypes (USNM 268446) deposited in the National Museum of Natural History, Smithsonian Institution, Washington, D.C. Remaining paratypes (dissected) in the collection of the author.

Female

Body (Fig. 1a,b) cyclopiform. Length $0.74 \mathrm{~mm}(0.70-0.77 \mathrm{~mm})$ and greatest width $0.29 \mathrm{~mm}$ $(0.29-0.30 \mathrm{~mm})$, based on 3 specimens. Greatest dorsoventral thickness $0.23 \mathrm{~mm}$. Somite bearing first pair of legs fused dorsally with cephalosome. Epimera of somites bearing legs 1-4 rounded. Ratio of length to width of prosome $1.78: 1$. Ratio of length of prosome to that of urosome $1.83: 1$.

Somite bearing leg 5 (Fig. 1c,d) $45 \times 112 \mu \mathrm{m}$. Genital double-somite elongate, $122 \times 104 \mu \mathrm{m}$ in greatest dimensions, ratio $1.17: 1$. In dorsal and ventral views side of somite with 2 pairs of small lateral expansions. In lateral view (Fig. 2a) somite slightly protuberant on ventral side and with small notch on dorsal side. Genital areas located laterally in anterior half of somite. Copulatory pore conspicuous, $35 \times 30 \mu \mathrm{m}$, located midventrally (Figs. 1d, 2b). Each genital area with 2 elements, 1 long weakly feathered seta $57 \mu \mathrm{m}$ and 1 shorter slightly recurved seta $13 \mu \mathrm{m}$. Three postgenital somites from anterior to posterior $44 \times 75,36 \times 70$, and $31 \times 68 \mu \mathrm{m}$. Anal somite with small setules posterior to operculum (Fig. 2c).

Caudal ramus (Fig. $2 \mathrm{c}$ ) short, $21 \times 26 \mu \mathrm{m}$, wider than long, ratio of length to width $0.8: 1$, bearing 6 setae. Outer lateral seta, placed dorsally, $50 \mu \mathrm{m}$, dorsal seta, set on small pedicel, $115 \mu \mathrm{m}$, and outermost terminal seta placed ventrally $50 \mu \mathrm{m}$, all smooth. Innermost terminal seta $150 \mu \mathrm{m}$ and 2 long median terminal setae $300 \mu \mathrm{m}$ (outer) and $440 \mu \mathrm{m}$ (inner), all with lateral setules, those on 2 median terminal setae especially strong and widely spaced.

Surface of body without visible sensilla except for pair on anterior surface of rostrum (Fig. 2e).

Egg sac not seen.

Rostrum (Fig. 2d,e) lobiform in lateral view, but appearing subtriangular in undissected animal. Antennule (Fig. 2g) $140 \mu \mathrm{m}$ long, 8-segmented. Lengths of segments : 9 (21 $\mu \mathrm{m}$ along anterior margin), $21,13,26,5,17,12$, and $15 \mu \mathrm{m}$, respectively. Armature : $2,13,4$ (1 of them short and spiniform), 4, 1,3,2, and $4+1$ aesthetasc. Many setae with strong lateral setules. Antenna (Fig. 3a) 2-segmented, $90 \mu \mathrm{m}$ long. First segment with 1 short proximal outer seta and 2 long marginal setae, 1 set on pedicel. Second segment with 15 setae. Many setae with lateral setules.

Labrum (Fig. 2e,f) triangular as seen in undissected animal (Fig. 2e), with median spherical protuberance, pair of dentiform spines, and pair of lateral groups of small setules. In dissection (Fig. 2f) posteroventral edge of labrum showing median protuberance with long marginal setules, 2 spines, and lateral setules. Mandible (Fig. 3b,c) with coxa having prominent gnathobase bearing 6 teeth, 1 long seta, 4 shorter setae, and few small spinules. Basis 


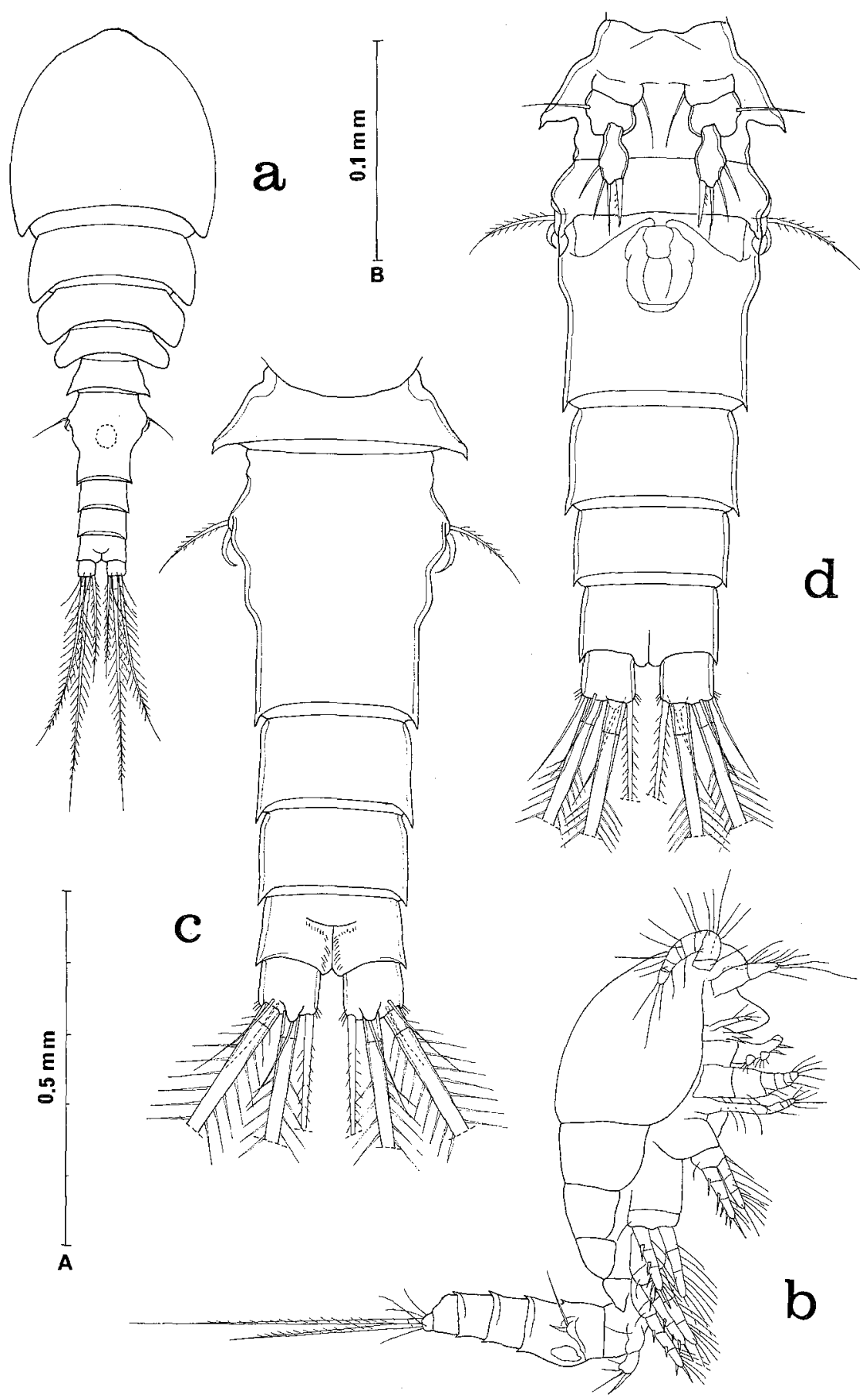

Fig. 1. Pterinopsyllus stirpipes, new species, female. a, body, dorsal (scale A); b, body, lateral (A); c, urosome, dorsal (B) ; d, urosome, ventral (B). 


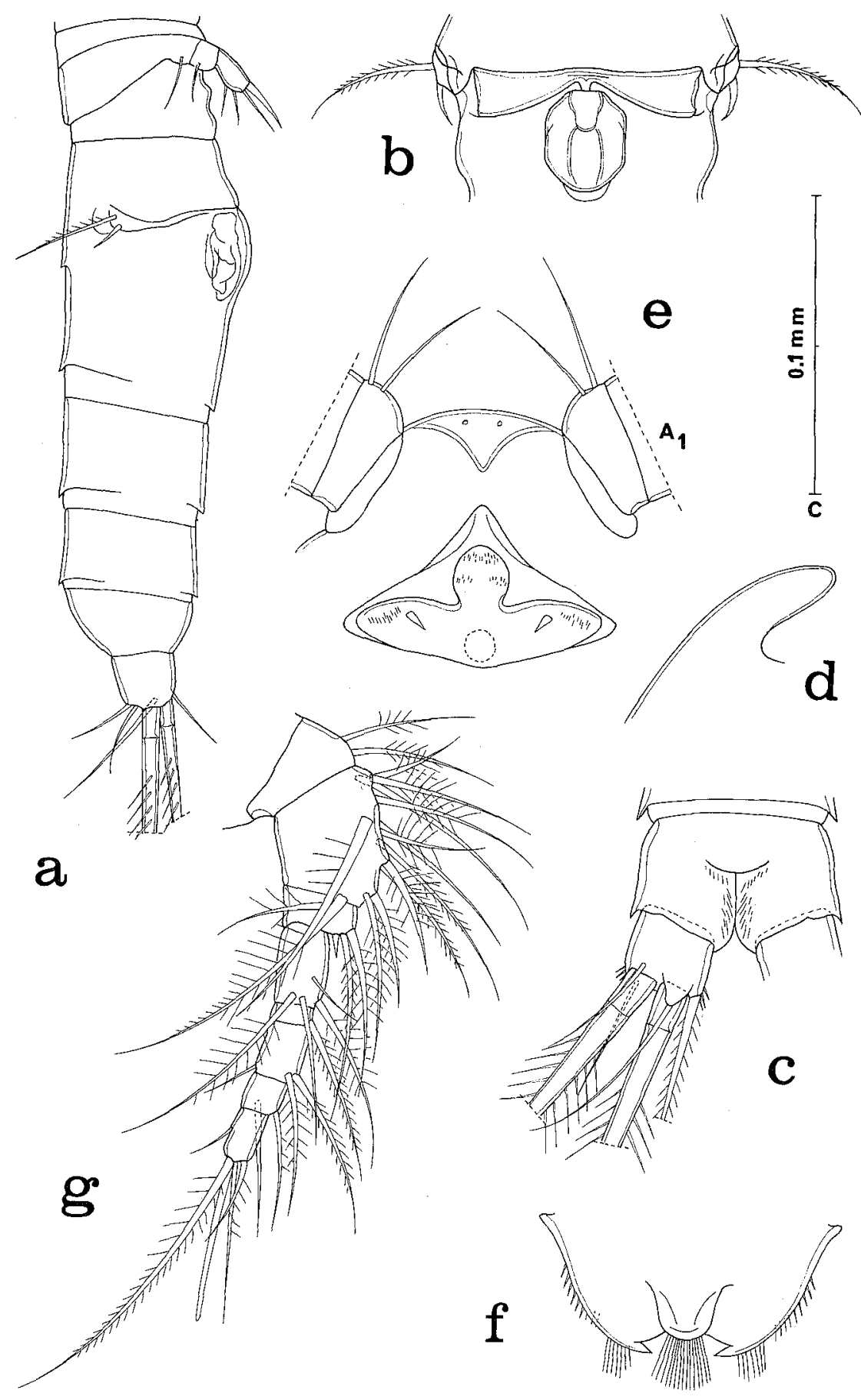

Fig. 2. Pterinopsyllus stirpipes, new species, female. a, urosome, lateral (scale B); b, genital opening, ventral $(C)$; $c$, anal somite and caudal ramus, dorsal $(C)$; d rostrum, lateral $(C)$; e, rostrum and labrum, ventral $(\mathrm{C})$; f, labrum, dorsal, in dissection $(\mathrm{C})$; $\mathrm{g}$, antennule, antero-inner $(\mathrm{C}) . \mathrm{A}_{\mathrm{i}}=$ antennule. 

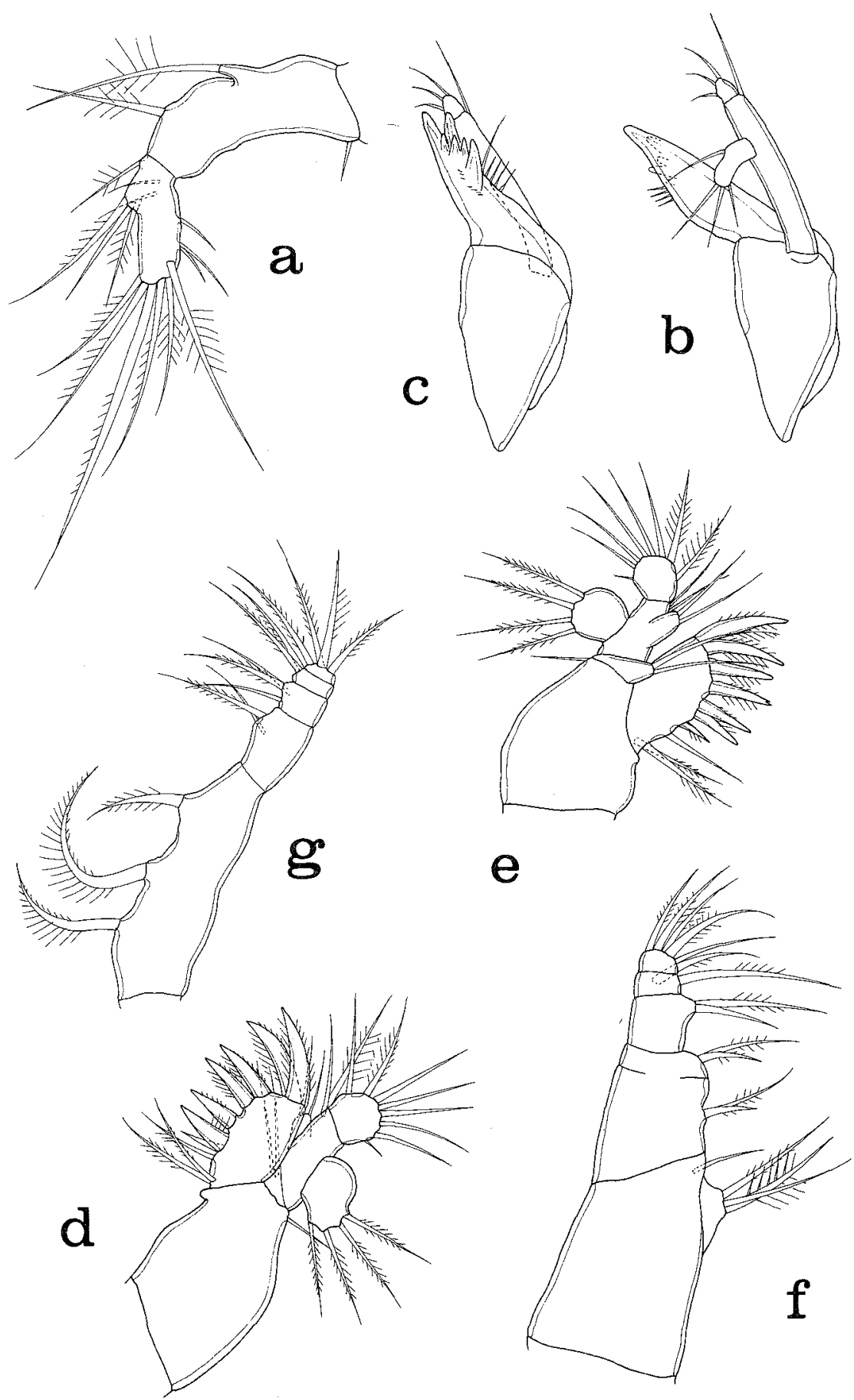

Fig. 3. Pterinopsyllus stirpipes, new species, female. a, antenna, inner (scale C); b, mandible, postero-outer $(\mathrm{C})$; c, mandible, antero-inner $(\mathrm{C})$; $d$, maxillule, posterior $(\mathrm{C})$; e, maxilla, anterior $(\mathrm{C})$; $\mathrm{f}$, maxilla, posterior $(\mathrm{C})$; g, maxilliped, posterior $(\mathrm{C})$. 

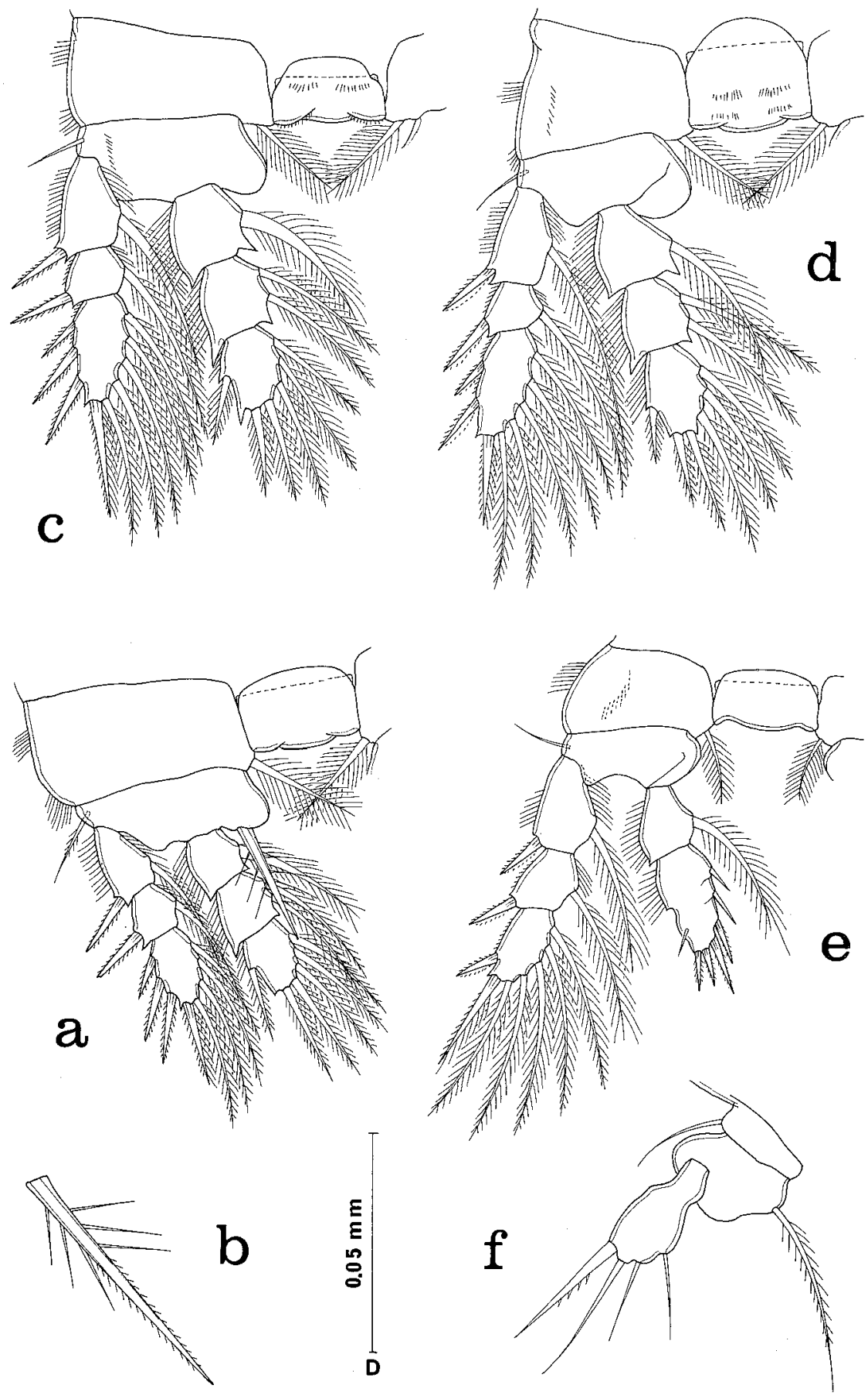

Fig. 4. Pterinopsyllus stirpipes, new species, female. a, leg 1 and intercoxal plate, anterior (scale B) ; $\mathrm{b}$, inner spine on basis, anterior (D); $\mathrm{c}$, leg 2 and intercoxal plate, posterior (B); d, leg 3 and intercoxal plate, posterior (B); e, leg 4 and intercoxal plate, anterior (B); f, leg 5 , ventral (D). 
elongate and slender, $65 \times 8 \mu \mathrm{m}$, bearing 1-segmented exopod and endopod, both with 4 setae. Paragnath small lobe with few setules. Maxillule (Fig. 3d,e) with praecoxa having 1 distal inner seta and bearing arthrite with 7 spines and 3 setae. Coxa short, bearing 2 inner setae representing endite. Basis with 2 endites, both with 2 setae. Exopod 1-segmented with 4 setae. Endopod also 1-segmented, but with 8 setae. Maxilla (Fig. 3f) with praecoxa having 2 endites bearing 3 and 1 setae, respectively. Coxa with 2 endites, both with 2 setae. Basis with 1 endite with 2 setae. Endopod with 2 segments bearing 2 and 5 setae. Maxilliped (Fig. 3g) with long coxa having 3 setae representing 3 endites. Basis with 2 setae. Endopod with 3 segments having 3,2 , and 4 setae.

Legs 1-4 (Fig. 4a,c-e) with 3-segmented rami, except 2-segmented endopod in leg 4. Armature as follows:

$\begin{array}{lllllllll}\mathrm{P}_{\perp} & \operatorname{coxa} & 0-1 & \text { basis } & 1-\mathrm{I} & \exp & \mathrm{I}-1 ; & \mathrm{I}-1 ; & \mathrm{III}, \mathrm{I}, 4 \\ & & & & & \operatorname{enp} & 0-1 ; & 0-2 ; & 1,2,3 \\ \mathrm{P}_{2} & \operatorname{coxa} & 0-1 & \text { basis } & 1-0 & \exp & \mathrm{I}-1 ; & \mathrm{I}-1 ; & \text { III,I,5 } \\ & & & & & \operatorname{enp} & 0-1 ; & 0-2 ; & 1,2,3 \\ \mathrm{P}_{3} & \operatorname{coxa} & 0-1 & \text { basis } 1-0 & \exp & \mathrm{I}-1 ; & \mathrm{I}-1 ; & \mathrm{II}, \mathrm{I}, 5 \\ & & & & & \operatorname{enp} & 0-1 ; & 0-2 ; & 1,2,3 \\ \mathrm{P}_{4} & \operatorname{coxa} & 0-1 & \text { basis } 1-0 & \text { exp } & \mathrm{I}-1 ; & \mathrm{I}-1 ; & \mathrm{I}, \mathrm{I}, 5\end{array}$

Intercoxal plates of legs 2 and 3 with paired rows of posterior surficial spinules (Fig. 4c, d) ; these spinules absent in legs 1 and 4 . Basis of leg 1 with prominent inner spine $52 \mu \mathrm{m}$ long, with few coarse strong setules proximally and finely barbed distally (Fig. 4b). Coxae of legs 3, 4 with posterior surficial row of small spinules. Leg 4 with exopod $107 \mu \mathrm{m}$, endopod $69 \mu \mathrm{m}$ long. First segment of endopod with long plumose inner seta; second segment with notch halfway on outer margin, followed by small seta, 2 terminal barbed spines, and on inner margin 2 barbed spines and 2 small setae, with suggestion of division of segment near insertion of these 2 setae. Both endopodal segments with long outer marginal setules.

Leg 5 (Fig. 4f) situated ventrally (Fig. 1d). Short coxa with inner smooth seta $20 \mu \mathrm{m}$, large basis with delicately plumose outer seta $39 \mu \mathrm{m}$. Free segment $22 \times 13 \mu \mathrm{m}$, narrow at base, expanded distally, with 4 elements, 1 inner spine $27 \mu \mathrm{m}$ with few small outer marginal spines, and 3 smooth setae, 30,16 , and $16 \mu \mathrm{m}$.

Leg 6 represented by 2 unequal setae on genital area (Fig. 2a,b).

Color of living specimens in transmitted light opaque gray, eye red.

Male. Unknown.

Etymology

The name of the species is formed from the Latin words stirps, a stem, and pes, a foot, alluding to the form of the third segment of leg 5 .

Remarks

Pterinopsyllus stirpipes differs from all six congeners in the stalked form of the third segment of leg 5 . In the congeners this segment is oval, suboval, or elongate, not constricted proximally as in the new species. Other differences are: in P. insignis Brady, 1880, the prosome is slightly produced forward, the third segment of the exopod of leg 3 has III,I,5 (see Sars, 1913, plate 10), and the second segment of the endopod of leg 4 has 1,2,II, the spines being short; in $P$. egregius Giesbrecht, 1900, the body length is $1 \mathrm{~mm}$ and the prosome is tapered anteriorly; in P. illustris Giesbrecht, 1900 , the body is longer, $0.85-0.90 \mathrm{~mm}$, and the third segment of leg 5 is elongate; in $P$. illgi M.S. Wilson, 1973 , the body length is $1.01 \mathrm{~mm}$ and the second segment of the endopod of leg 4 bears two setae and three short spines; in $P$. giesbrechti M.S. Wilson, 1973 the prosome is tapered anteriorly, the antennule is 11 -segment- 
ed, and the antenna is 4-segmented (this species has been removed to a new genus, Pterinopsyllotus, by Herbst (1989); and in P. insularis Herbst, 1989, the antennule is 10-segmented, the second segment of the endopod of leg 4 bears five spines.

Herbst (1989) published a key to the species of Pterinophyllus known at that time.

All species of Pterinopsyllus are free-living, except for the association noted in the case of $P$. stirpipes and the record of $P$. insularis from the corallimorpharian Ricordea florida Duchaissang and Michelotti in Puerto Rico (Herbst, 1989).

Order Poecilostomatoida Thorell, 1859

Family Anchimolgidae Humes \& Boxshall, 1996

Genus Anchimolgus Humes \& Stock, 1972

\section{Anchimolgus nasutus, new species}

(Figs. 5-9)

Type material. 7 우우, 6 송 from Galaxea fascicularis (L.), in $2 \mathrm{~m}$, Ricaudy Reef, near Noumea, New Caledonia, $22^{\circ} 19^{\prime} 00^{\prime \prime} \mathrm{S}, 166^{\circ} 26^{\prime} 44^{\prime \prime} \mathrm{E}$, 25 vi 1971. Holotype 우 (USNM 268447), allotype 옹 (USNM 268448), and 9 paratypes ( 5 우우, 4 상ㄱㅇ (USNM 268449) deposited in the National Museum of Natural History, Smithsonian Institution, Washington, D.C. Remaining paratypes, 1 우, 1 스, dissected, in the collection of the author.

Additional material. 2 우우, 1 송 from Galaxea fascicularis, in $3 \mathrm{~m}$, Karang Mie, Weda Bay, eastern Halmahera, Moluccas, $00^{\circ} 20^{\prime} 07^{\prime \prime} \mathrm{N}, 128^{\circ} 25^{\prime} 00^{\prime \prime} \mathrm{E}, 19 \mathrm{v} 1971$.

Male

Body (Fig. $5 \mathrm{a}, \mathrm{b})$ with prosome moderately slender. Length $1.43 \mathrm{~mm}(1.30-1.46 \mathrm{~mm})$ and greatest width $0.41 \mathrm{~mm}(0.40-0.42 \mathrm{~mm})$, based on 5 specimens. Greatest dorsoventral thickness $0.35 \mathrm{~mm}$. Somite bearing leg 1 separated from cephalosome by dorsal transverse suture. Epimera of metasomal somites in dorsal view moderately pointed (Fig. 5a) but in lateral view broadly rounded (Fig. 5b). Ratio of length to width of prosome $1.97: 1$. Ratio of length of prosome to that of urosome $1.14: 1$.

Somite bearing leg 5 (Fig. 5c) $65 \times 177 \mu \mathrm{m}$. Genital somite in dorsal view $250 \mu \mathrm{m}$ long (265 $\mu \mathrm{m}$ including leg 6$) \times 250 \mu \mathrm{m}$ wide. Four postgenital somites from anterior to posterior $52 \times$ $109,57 \times 107,47 \times 104$, and $50 \times 102 \mu \mathrm{m}$.

Caudal ramus (Fig. 5d) $128 \times 47 \mu \mathrm{m}$, unornamented, ratio of length to width $2.72: 1$. Outer lateral seta, placed somewhat dorsally, $240 \mu \mathrm{m}$ long, dorsal seta $55 \mu \mathrm{m}$, outermost terminal seta $107 \mu \mathrm{m}$, innermost terminal seta $175 \mu \mathrm{m}$, and 2 median terminal setae $253 \mu \mathrm{m}$ (outer) and $340 \mu \mathrm{m}$ (inner). All setae with lateral setules, except smooth dorsal seta.

Dorsal surface of prosome with sensilla, more numerous on prosome than on urosome (Fig. 5a-c).

Rostrum (Fig. 5e,f) elongate, linguiform, approximately $130 \mu \mathrm{m}$ long. Antennule (Fig. 6a) $312 \mu \mathrm{m}$ long. Lengths of its 7 segments : 49 (55 $\mu \mathrm{m}$ along anterior margin), $78,26,55,44,41$, and $26 \mu \mathrm{m}$, respectively. Formula for armature : $4,13+2$ aesthetascs, $6,3+1$ aesthetasc, $4+$ 1 aesthetasc, $2+1$ aesthetasc, and $7+1$ aesthetasc. Antenna (Fig. 6b) $280 \mu \mathrm{m}$ long, 4-segmented. Formula for armature: 1, 0,2, and 1 claw. Second segment with many minute scalelike knobs on inner surface; usual seta on this segment not visible. Third segment with only 2 setae. Fourth segment $81 \mu \mathrm{m}$ along outer side, $65 \mu \mathrm{m}$ along inner side (with few small knobs), width $18 \mu \mathrm{m}$. Claw $47 \mu \mathrm{m}$.

Labrum as in female (Fig. 8d). Mandible (Fig. 6c), maxillule (Fig. 6d), and maxilla (Fig. 6e) similar to those of congeners. Maxilliped (Fig.6f) with first segment unarmed, second 


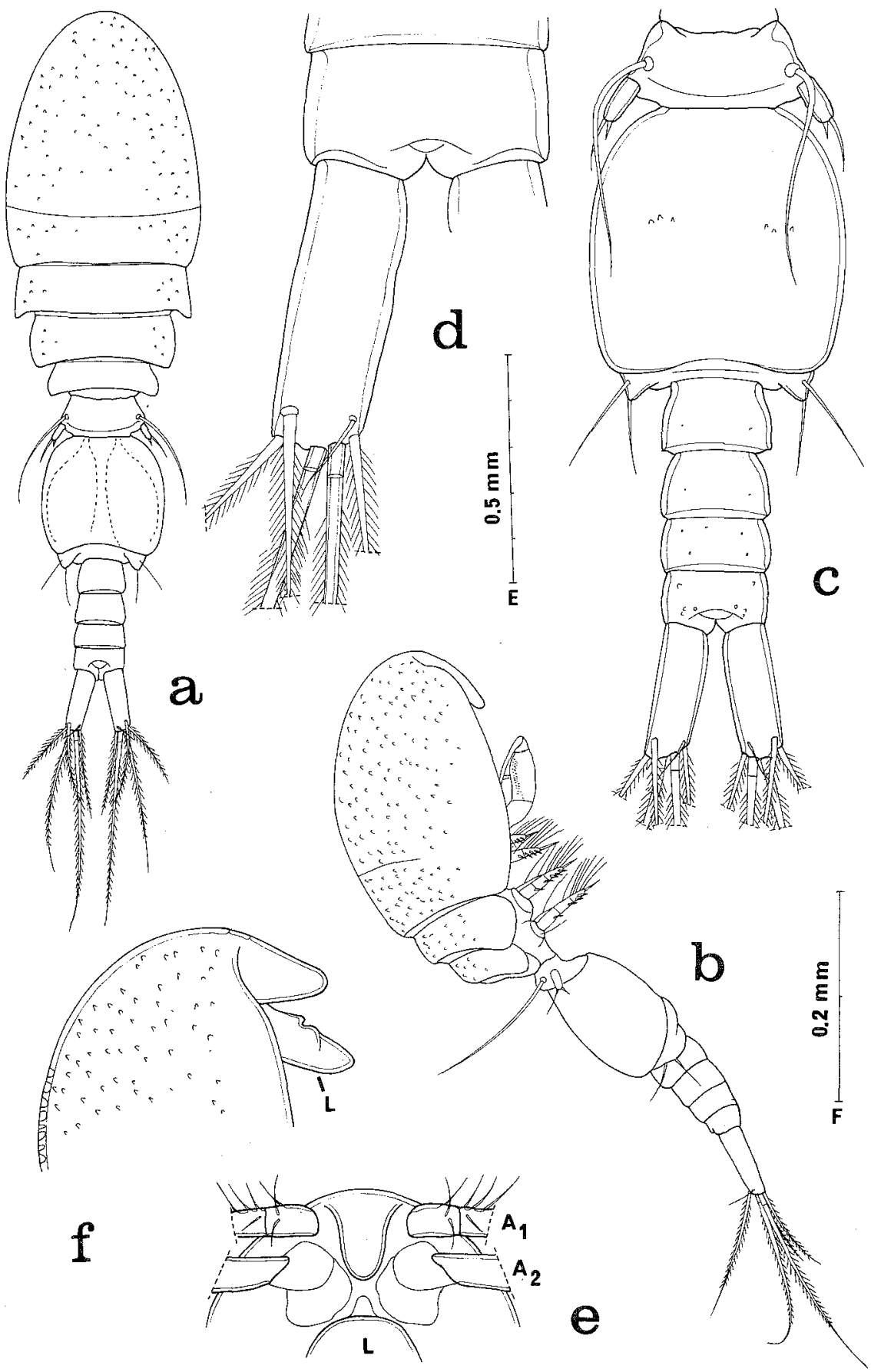

Fig. 5. Anchimolgus nasutus, new species, male. a, body, dorsal (scale E) ; b, body, lateral (E); c, urosome, dorsal $(\mathrm{F})$; d, anal somite and caudal ramus, dorsal $(\mathrm{B})$; e, rostrum, ventral (A); f, rostrum and labrum, lateral (A). $A_{1}=$ antennule, $A_{2}=$ antenna, $\mathrm{L}=$ labrum. 


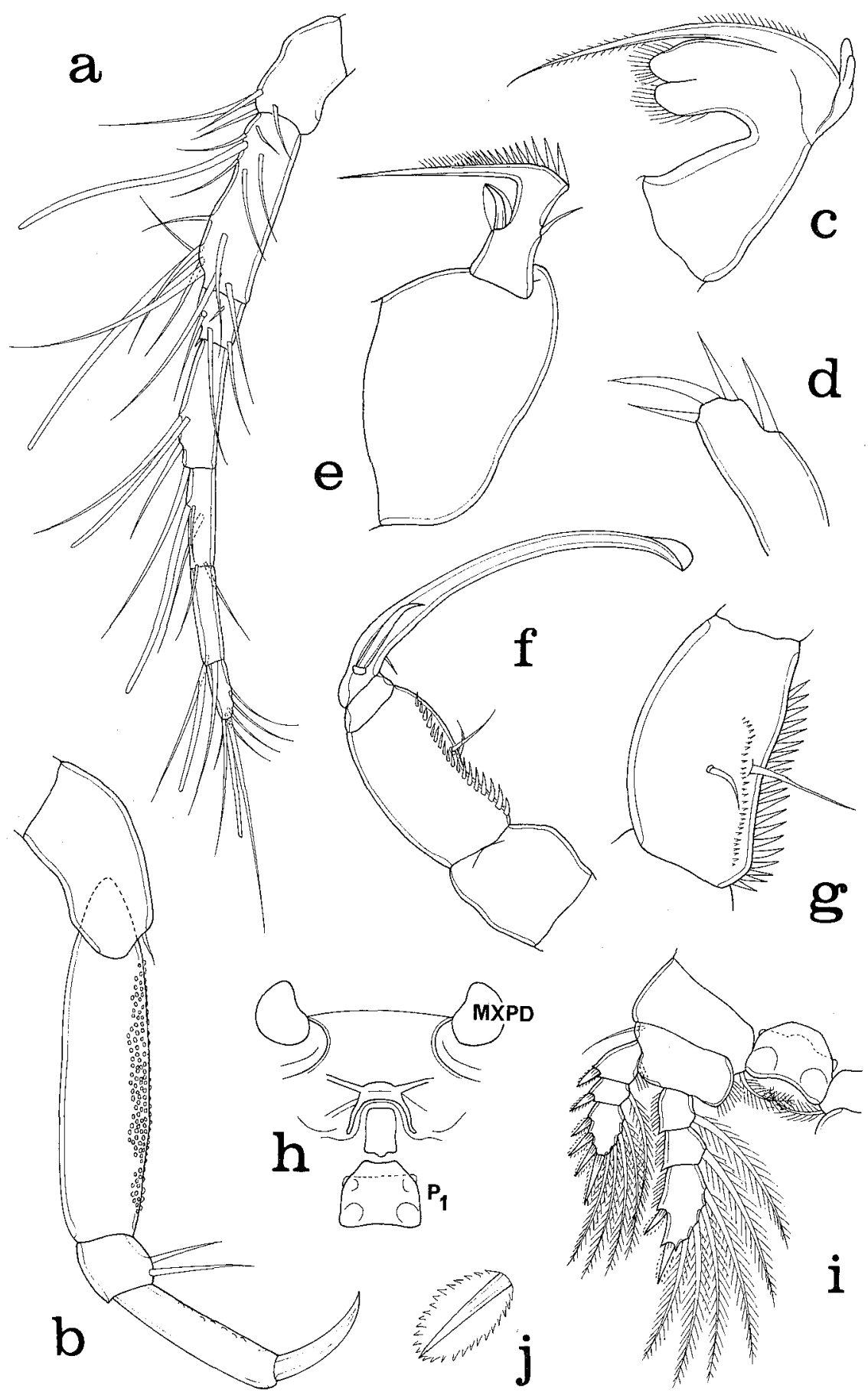

Fig. 6. Anchimolgus nasutus, new species, male. a, antennule, dorsal (scale B) ; b, antenna, posteroouter (B); c, mandible, posterior (C); d, maxillule, posterior (D); e, maxilla, posterior (C); $f$, maxilliped, inner $(G)$; g, second segment of maxilliped, antero-inner $(B)$; h, area between maxillipeds and first pair of legs, ventral $(F)$; i, leg 1 and intercoxal plate, anterior $(F) ; j$, outer spine on third segment of exopod of leg 1 , anterior (D). MXPD = maxilliped, $\mathrm{P}_{1}=\operatorname{leg} 1$. 
segment with 2 inner setae and 2 rows of spinules, one row large, one row small (Fig. $6 \mathrm{~g}$ ). Third segment small and unarmed. Claw $252 \mu \mathrm{m}$ long including terminal lamella, $242 \mu \mathrm{m}$ without lamella, bearing 2 very unequal proximal setae.

Ventral area between maxillipeds and first pair of legs (Fig. 6h) slightly protuberant.

Legs 1-4 (Figs. 6i, 7a-c) with 3-segmented rami, except for 2-segmented endopod of leg 4. Formula for armature:

\begin{tabular}{|c|c|c|c|c|c|c|c|c|}
\hline$P_{1}$ & coxa & $0-1$ & basis & $1-0$ & $\begin{array}{l}\exp \\
\text { enp }\end{array}$ & $\begin{array}{l}\mathrm{I}-0 ; \\
0-1 ;\end{array}$ & $\begin{array}{l}\mathrm{I}-1 \\
0-1\end{array}$ & $\begin{array}{c}\mathrm{III}, \mathrm{I}, 4 \\
\mathrm{I}, \mathrm{I}, 4\end{array}$ \\
\hline $\mathrm{P}_{2}$ & coxa & $0-1$ & basis & $1-0$ & $\exp$ & $\mathrm{I}-0$; & $\mathrm{I}-1$ & III,I,5 \\
\hline & & & & & enp & $0-1$; & $0-2$; & $\mathrm{I}, \mathrm{II}, 3$ \\
\hline $\mathrm{P}_{3}$ & coxa & $0-1$ & basis & $1-0$ & $\exp$ & I-0; & $\mathrm{I}-1$; & III,I,5 \\
\hline & & & & & enp & $0-1$; & $0-2$; & I,II,2 \\
\hline $\mathrm{P}$ & coxa & $0-1$ & basis & $1-0$ & $\begin{array}{l}\text { exp } \\
\text { enp }\end{array}$ & $\begin{array}{l}\text { I- } 0 ; \\
0-1 ;\end{array}$ & $\begin{array}{l}\text { I-1; } \\
\text { II }\end{array}$ & II,I,5 \\
\hline
\end{tabular}

Certain spines on third segment of exopod of leg 1 with serrate lamellae (Fig. 6j). Leg 4 with exopod $150 \mu \mathrm{m}$. Endopod (Fig. 7d) with first segment $29 \times 21 \mu \mathrm{m}$, its plumose seta $49 \mu \mathrm{m}$; second segment $44 \times 22 \mu \mathrm{m}$, its 2 terminal barbed spines 24 and $52 \mu \mathrm{m}$.

Leg 5 (Fig. 7e) with unornamented free segment $47 \times 15.5 \mu \mathrm{m}$, ratio $3.03: 1$, bearing 1 long seta $73 \mu \mathrm{m}$ and 1 short spiniform seta $11 \mu \mathrm{m}$. Seta on body adjacent to insertion of free segment very long, $216 \mu \mathrm{m}$. All setae smooth.

Leg 6 (Fig. 7f) with 2 slender setae 80 and $70 \mu \mathrm{m}$.

Spermatophore seen only inside body (Fig. 5a).

Color of living specimens in transmitted light opaque gray, eye red.

Female

Body (Figs. 7g, 8a) $1.67 \mathrm{~mm}(1.56-1.82 \mathrm{~mm})$ and greatest width $0.53 \mathrm{~mm}(0.50-0.55 \mathrm{~mm})$, based on 5 specimens. Greatest dorsoventral thickness $0.52 \mathrm{~mm}$. Ratio of length to width of prosome $1.72: 1$. Ratio of length of prosome to that of urosome $1.16: 1$.

Somite bearing leg 5 (Fig. $8 \mathrm{~b}$ ) $83 \times 250 \mu \mathrm{m}$. Genital double-somite in dorsal view elongate, $265 \mu \mathrm{m}$ long, anterior two-thirds with lateral margins slightly rounded, width $237 \mu \mathrm{m}$, posterior third narrower with lateral margins parallel, width $169 \mu \mathrm{m}$. Transverse dorsal sclerotization at junction of these 2 regions. In lateral view genital double-somite $226 \times 53 \mu \mathrm{m}$, ratio $4.26: 1$. Genital areas located dorsolaterally near middle of somite. Each area (Fig. $8 \mathrm{c}$ ) with 2 very minute setae. Three postgenital somites from anterior to posterior $107 \times 156,81 \times 153$, and $78 \times 135 \mu \mathrm{m}$.

Caudal ramus (Fig. 8b) $172 \times 55 \mu \mathrm{m}$, ratio $3.13: 1$, resembling that of male.

Sensilla on dorsal surface of body as in Figs. 7g, 8a,b.

Rostrum (Fig. 8d,e) unusually long, approximately $165 \mu \mathrm{m}$, slender, slightly broader distally than proximally. Antennule as in male, but lacking aesthetascs on segments 2 and 4. Antenna (Fig. 9a) $331 \mu \mathrm{m}$ long. Formula as in male. Second segment showing minute hyaline area perhaps representing position of former seta; this segment with smooth inner surface.

Labrum (Fig. 9b) with 2 broadly rounded posteroventral lobes. These lobes not evident in undissected specimen (as in Fig. 8d). Mandible, maxillule, and maxilla as in male. Paragnath minute rounded lobe. Maxilliped (Fig. 9c) resembling that of congeners.

Ventral area between maxillipeds and first pair of legs as in male.

Legs 1-4 resembling those of male, except sexual dimorphism in endopod of leg 1 , with third segment having I,5 (Fig. 9d).

Leg 5 (Fig. 8b) with free segment in dorsal view showing slight inner proximal expansion. Length $239 \mu \mathrm{m}$, width at expansion $45 \mu \mathrm{m}$, width distally $21 \mu \mathrm{m}$. In flat view free segment as 


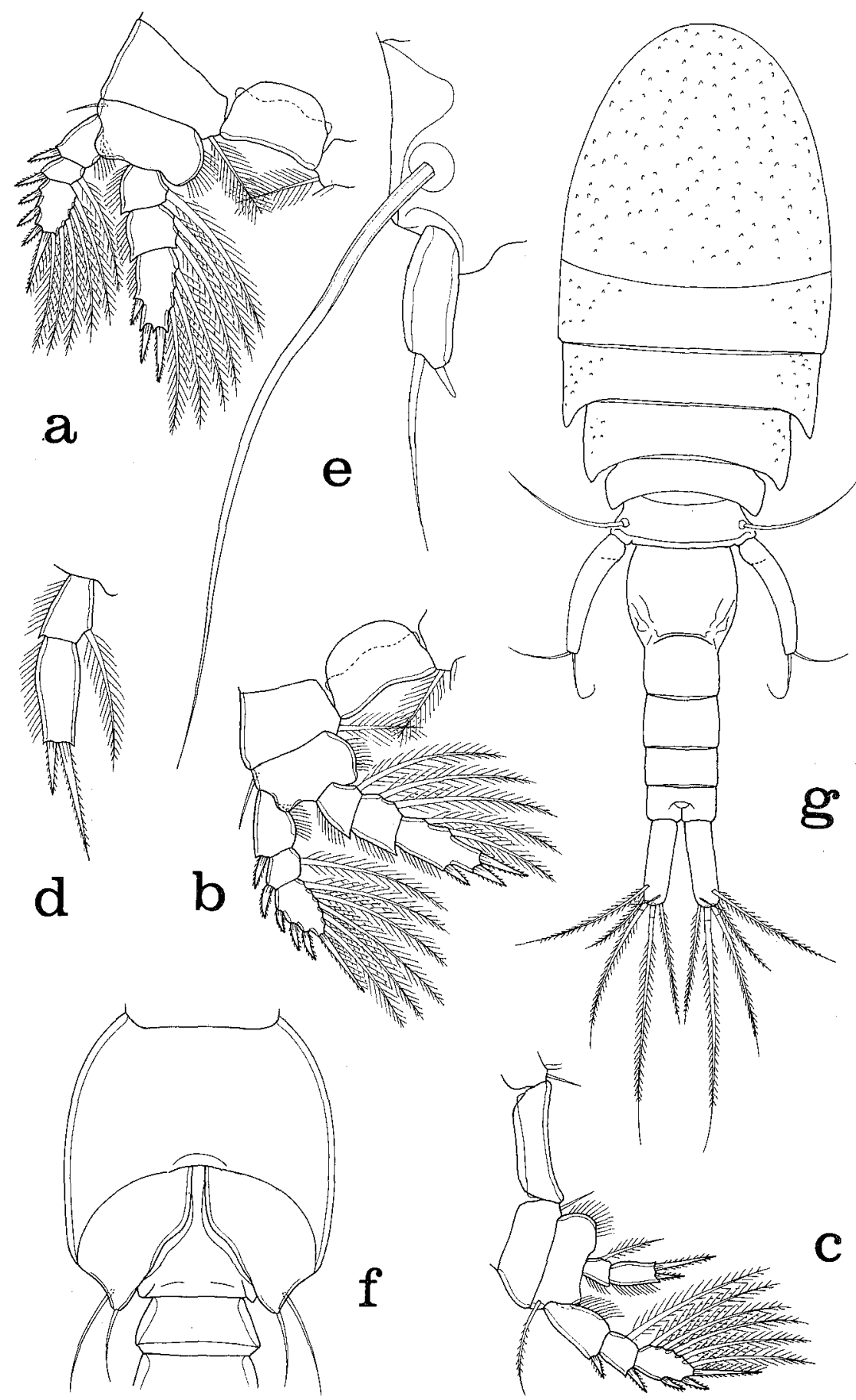

Fig. 7. Anchimolgus nasutus, new species. Male. a, leg 2 and intercoxal plate, anterior (scale F); b, leg 3 and intercoxal plate, anterior $(F)$; c, leg 4 and intercoxal plate, posterior $(F)$; d, endopod of leg 4, posterior (B); e, leg 5, dorsal (C); f, genital somite showing leg 6, ventral (F). Female. g, body, dorsal (E). 


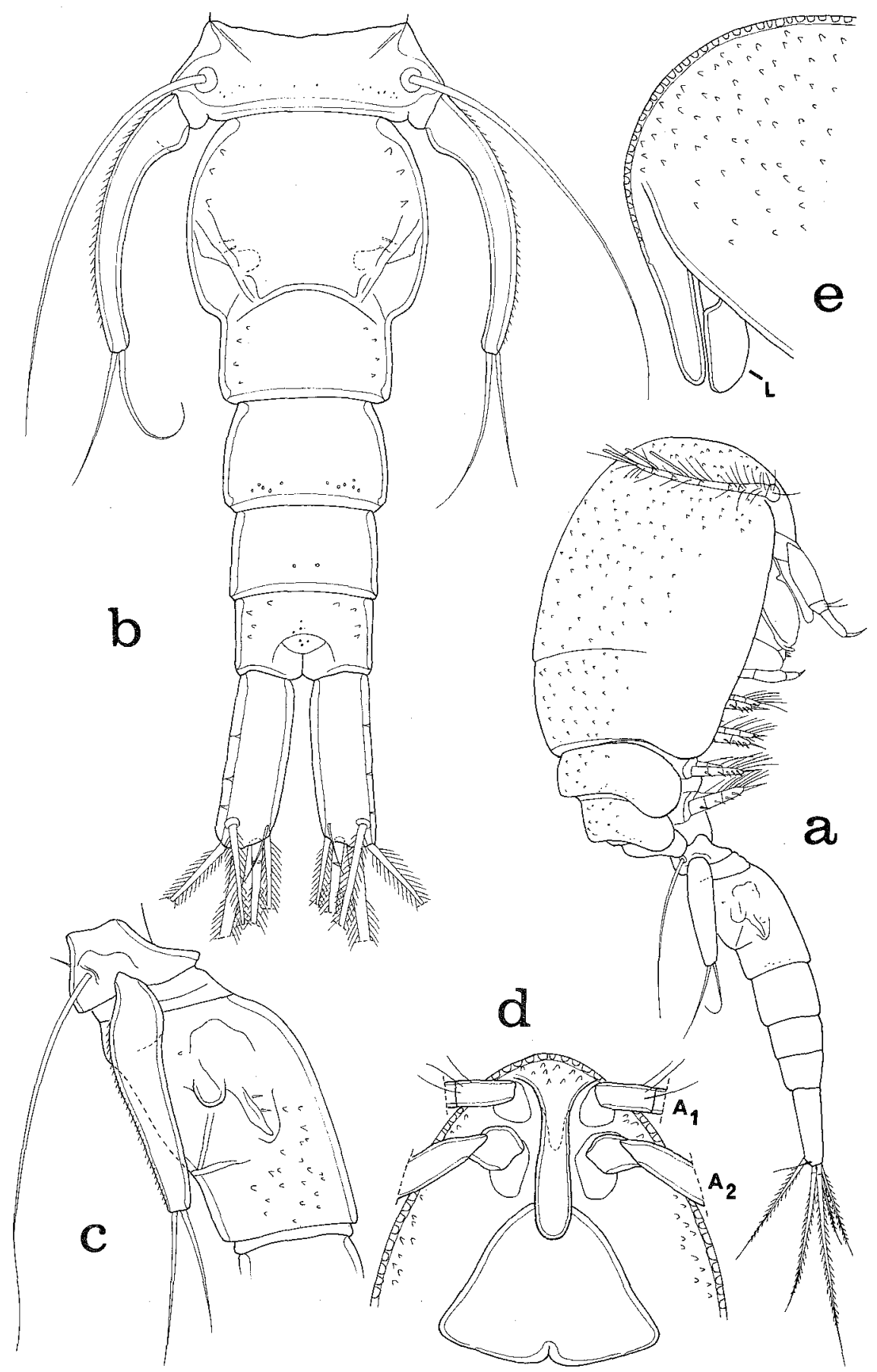

Fig. 8. Anchimolgus nasutus, new species, female. a, body, lateral (scale E); b, urosome, dorsal (F); $c$, somite bearing leg 5 and genital double-somite, lateral $(F) ; d$, rostrum and labrum, ventral $(A)$; e, rostrum and labrum, lateral $(\mathrm{A}) . \mathrm{A}_{1}=$ antennule, $\mathrm{A}_{2}=$ antenna, $\mathrm{L}=$ labrum. 

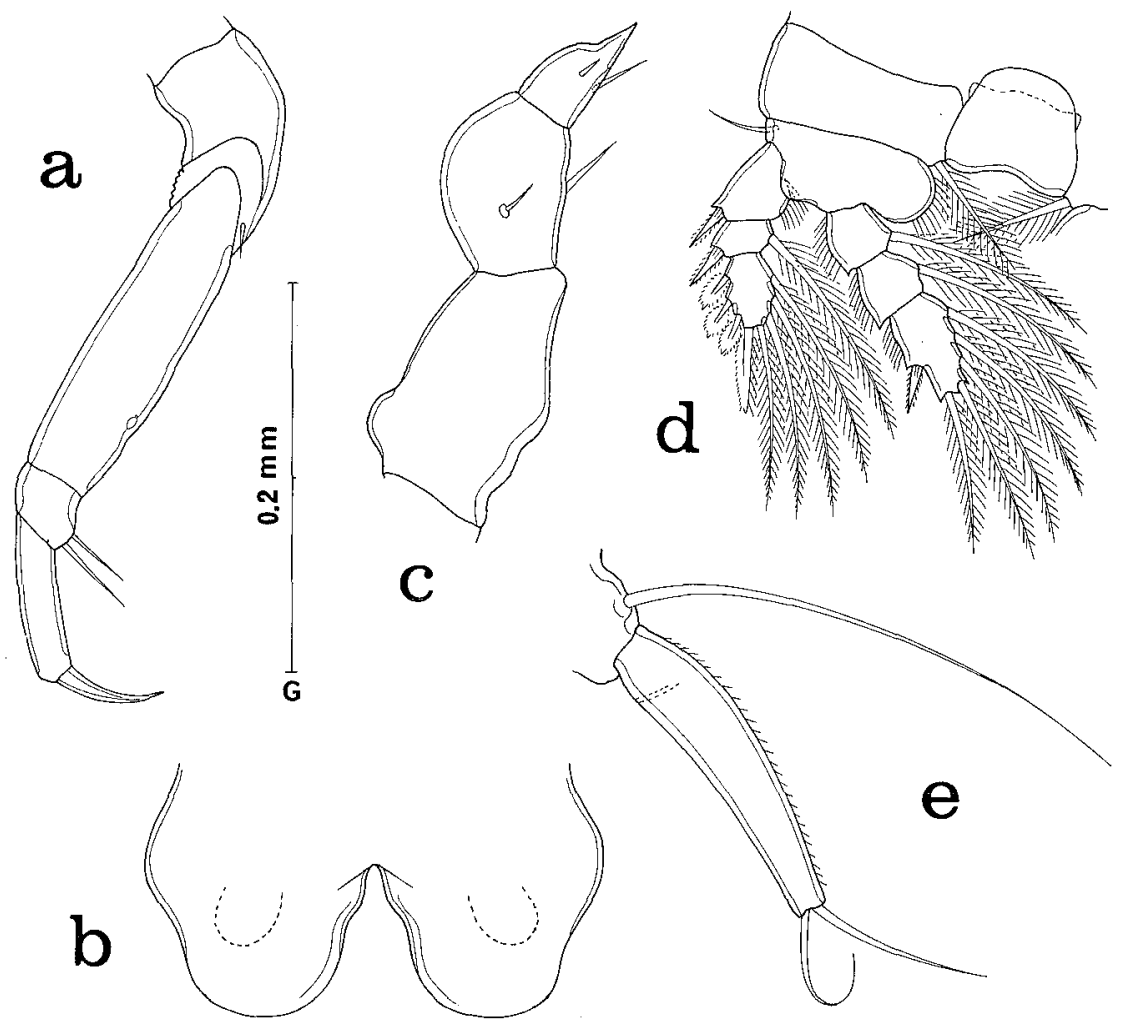

e

Fig. 9. Anchimolgus nasutus, new species, female. a, antenna, antero-outer (scale G); b, labrum, ventral $(B)$; c, maxilliped, inner (B) ; d, leg 1 and intercoxal plate, anterior (F); e, leg 5, dorsolateral flat view $(\mathrm{F})$.

in Fig. 9e. Two terminal setae 122 and $177 \mu \mathrm{m}$. Small spinules along outer surface of free segment. Seta on body near insertion of free segment very long, $330 \mu \mathrm{m}$. All setae smooth.

Leg 6 represented by 2 minute setae on genital area (Fig. 8c).

Color of living specimens as in male.

Etymology

The name nasutus, Latin meaning with a large nose, alludes to the unusually long rostrum.

Remarks

Anchimolgus nasutus may be distinguished from all congeners by the long snoutlike rostrum and the unusually long seta located dorsally and adjacent to the insertion of the free segment of leg 5 . Other features of special interest are the setation of the antenna, without a seta on the second segment and only two setae on the third segment.

\section{Anchimolgus compressus, new species}

(Figs. 10-12)

Type material. 5 우 우, $7 \hat{\circ}$ 스 from Galaxea fascicularis (L.), in $2 \mathrm{~m}$, Ricaudy Reef, near Noumea, New Caledonia, $22^{\circ} 19^{\prime} 00^{\prime \prime} \mathrm{S}, 166^{\circ} 26^{\prime} 44^{\prime \prime} \mathrm{E}$, 25 vi 1971. Holotype 우 (USNM 268450), allotype ô (USNM 
268451), and 8 paratypes ( 3 우우, 5 송스) (USNM 268452) deposited in the National Museum of Natural History, Smithsonian Institution, Washington, D.C. Remaining paratypes, 1 우, $1 \hat{0}$, dissected, in the collection of the author.

Additional material. 5 우우, 1 令 from Galaxea fascicularis, in $3 \mathrm{~m}$, Karang Mie, Weda Bay, eastern Halmahera, Moluccas, $00^{\circ} 20^{\prime} 07^{\prime \prime} \mathrm{N}, 128^{\circ} 25^{\prime} 00^{\prime \prime} \mathrm{E}, 19$ v 1975.

Female

Body (Fig. 10a,b) with prosome laterally compressed. Length $1.55 \mathrm{~mm}(1.52-1.58 \mathrm{~mm})$ and greatest width $0.31 \mathrm{~mm}(0.30-0.32 \mathrm{~mm})$, based on 5 specimens. Greatest dorsoventral thickness $0.47 \mathrm{~mm}$. Somite bearing first pair of legs separated dorsally from cephalosome by transverse suture. Epimeral areas of metasomal somites rounded. Ratio of length to width of prosome $2.40: 1$. Ratio of length of prosome to that of urosome $1.14: 1$.

Somite bearing leg 5 (Fig. 10c) $83 \times 213 \mu \mathrm{m}$. Genital double-somite in dorsal view $224 \times$ $185 \mu \mathrm{m}$, longer than wide, slightly wider in anterior half, ratio of length to width $1.21: 1$, lateral margins smooth. Somite showing dorsal transverse sclerotized bar near midregion, at point of indentation seen in lateral view (Fig. 10d). Genital areas located dorsolaterally at level of widest part of somite, bearing 2 minute setae. Three postgenital somites from anterior to posterior $104 \times 130,81 \times 114$, and $75 \times 109 \mu \mathrm{m}$.

Caudal ramus (Fig. 10e) elongate, $164 \times 49 \mu \mathrm{m}$, ratio $3.35: 1$. Outer lateral seta, inserted dorsally, $55 \mu \mathrm{m}$, dorsal seta $12 \mu \mathrm{m}$, outermost terminal seta $68 \mu \mathrm{m}$, innermost terminal seta $73 \mu \mathrm{m}$, and 2 median terminal setae $104 \mu \mathrm{m}$ (outer) and $133 \mu \mathrm{m}$ (inner). All setae smooth.

Body surface with prosome apparently smooth, but urosome dorsally with numerous sensilla (pores?) (Fig. 10c).

Egg sac unknown.

Rostrum (Fig. 10f) weakly developed but protruding slightly in lateral view (Fig. 10b). Antennule (Fig. 11a) $253 \mu \mathrm{m}$ long. Lengths of its 7 segments: $16(47 \mu \mathrm{m}$ along anterior margin), 75, 29, 33, 33, 26, and $18 \mu \mathrm{m}$, respectively. Armature: 4, 13, 6, 3, $4+1$ aesthetasc, $2+$ 1 aesthetasc, and $7+1$ aesthetasc (positions of 3 aesthetascs added in male indicated by dots). All setae smooth. Antenna (Fig. 11b) $273 \mu \mathrm{m}$ long, 4-segmented, unornamented. Both first and second segments with small seta. Third segment with 3 setae. Fourth segment with recurved claw $23 \mu \mathrm{m}$.

Labrum (Fig. 11c) with 2 diverging rounded posteroventral lobes. Mandible (Fig. 11d) with convex side bearing 2 digitiform lobes and 3 minute adjacent lobes. Paragnath not seen. Maxillule (Fig. 11e) with 2 setae. Maxilla (Fig. 11f) with second segment bearing usual 2 unequal setae and terminal lash. Maxilliped (Fig. 11g) armed with 2 setae on second segment and 2 unequal setae and terminal spine on third segment.

Ventral area between maxillipeds and first pair of legs protruding ventrally (Fig. 10b) and similar to that of male (Fig. 12d).

Legs 1-4 (Figs. 11h-j, 12a) with segmentation and formula for armature as in $A$. nasutus, above. Intercoxal plate in leg 1 narrow (Fig. 11h). Leg 4 (Fig. 12a) with exopod $133 \mu \mathrm{m}$ long. Endopod with first segment $24 \times 23 \mu \mathrm{m}$, its inner plumose seta $65 \mu \mathrm{m}$; second segment $45 \times 22$ $\mu \mathrm{m}$, its 2 terminal spines $22 \mu \mathrm{m}$ and $35 \mu \mathrm{m}$. Both segments with outer marginal setules.

Leg 5 (Fig. 12b) with unornamented free segment $60 \times 23 \mu \mathrm{m}$, ratio $2.61: 1$. Two terminal setae 52 and $73 \mu \mathrm{m}$. Adjacent seta on body near insertion of free segment $65 \mu \mathrm{m}$. All setae smooth.

Leg 6 represented by 2 minute setae on genital area (Fig. 10c,d).

Color of living specimens in transmitted light opaque gray, eye red.

Male

Body (Fig. 12c,d) with laterally compressed prosome. Length $1.26 \mathrm{~mm}(1.21-1.30 \mathrm{~mm})$ and 


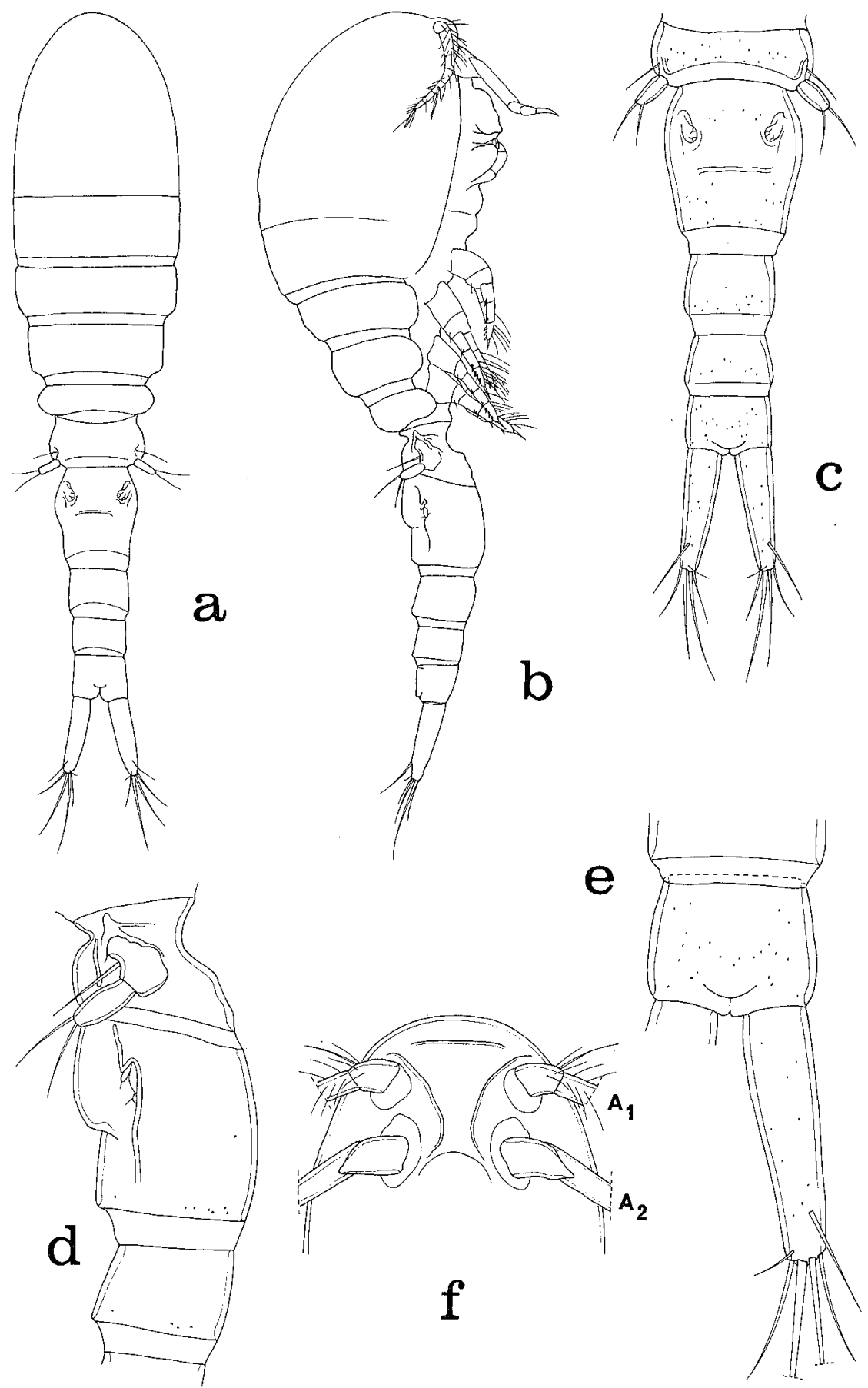

Fig. 10. Anchimolgus compressus, new species, female. a, body, dorsal (scale E) ; b, body, lateral (E) ; c, urosome, dorsal (A); d, somite bearing leg 5 and genital double-somite, lateral (F); e, anal somite and caudal ramus, dorsal $(G) ; f$, rostral area, ventral $(F) . A_{1}=$ antennule, $A_{2}=$ antenna. 


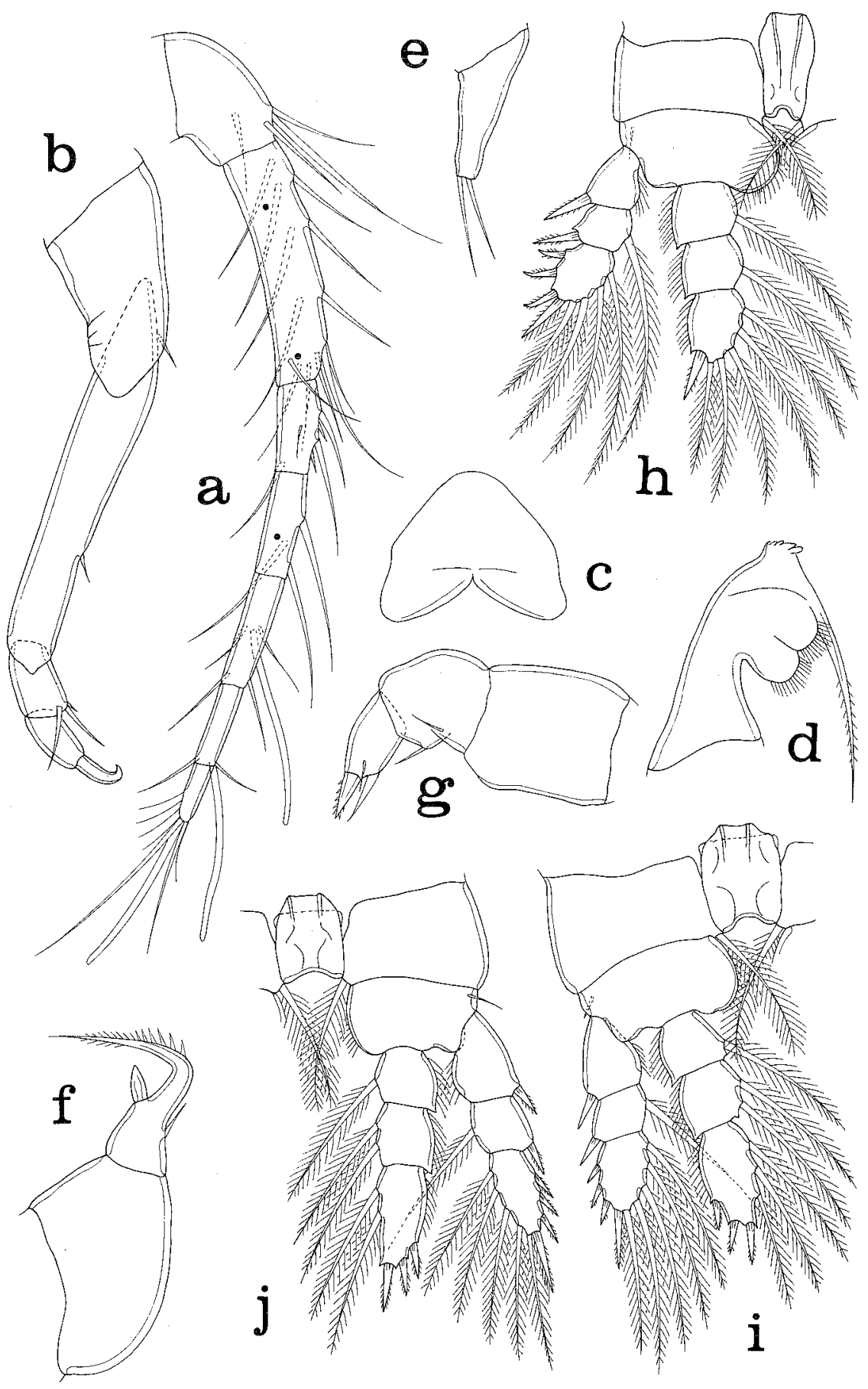

Fig. 11. Anchimolgus compressus, new species, female. a, antennule, with dots indicating positions of three aesthetascs added in male, dorsal (scale $\mathrm{C}) ; b$, antenna, postero-outer $(\mathrm{B})$; $c$, outline of labrum, ventral $(G)$; d, mandible, anterior $(C)$; e, maxillule, posterior (C); f, maxilla, anterior (C); g, maxilliped, inner (C) ; h, leg 1 and intercoxal plate, anterior $(G)$; i, leg 2 and intercoxal plate, anterior (G) ; j, leg 3 and intercoxal plate, posterior $(G)$. 


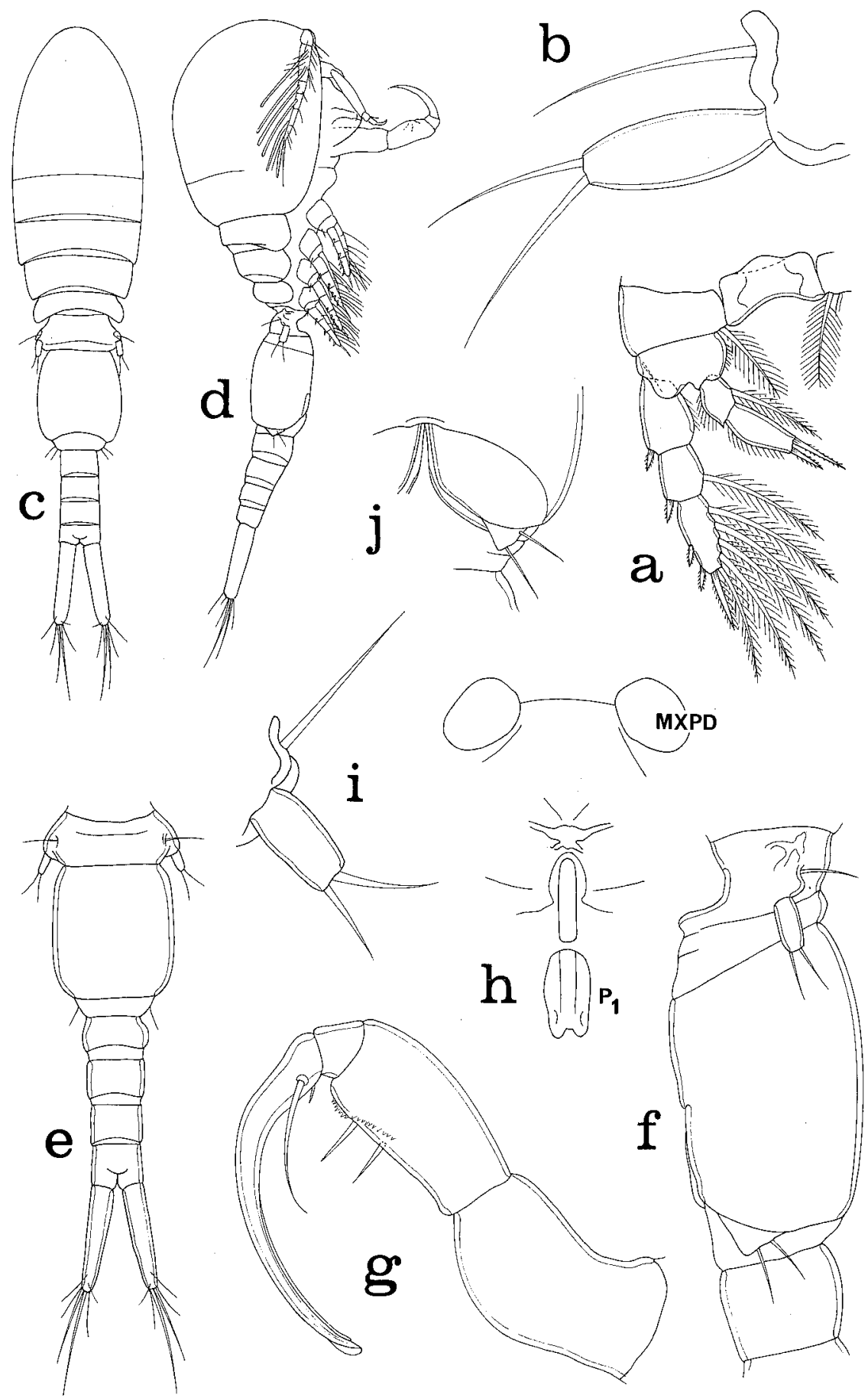

Fig. 12. Anchimolgus compressus, new species, female. a, leg 4 and intercoxal plate (scale G); b, leg 5, lateral (C). Male. c, body, dorsal (E) ; d, body, lateral (E) ; e, urosome, dorsal (A) ; f, somite bearing leg 5 and genital somite, lateral $(G) ; g$, maxilliped, inner $(C) ; h$, area between maxillipeds and first pair of legs, ventral (B); i, leg 5, lateral $(C)$; j, leg 6, ventral $(G) . M X P D=$ maxilliped, $P_{1}=\operatorname{leg} 1$. 
greatest width $0.26 \mathrm{~mm}(0.25-0.28 \mathrm{~mm})$, based on 4 specimens. Greatest dorsoventral thickness $0.30 \mathrm{~mm}$. Ratio of length to width of prosome $2.22: 1$. Ratio of length of prosome to that of urosome $0.91: 1$.

Somite bearing leg 5 (Fig. 12e) $62 \times 190 \mu \mathrm{m}$. Genital segment elongate (Fig. 12f), in dorsal view longer than wide, $203 \times 179 \mu \mathrm{m}$, ratio $1.13: 1$, with subparallel lateral margins. Four postgenital somites from anterior to posterior $57 \times 95,57 \times 88,49 \times 82$, and $60 \times 78 \mu \mathrm{m}$.

Caudal ramus (Fig. 12e) $140 \times 30 \mu \mathrm{m}$, ratio $4.77: 1$, similar to that of female but smaller.

Rostrum as in female. Antennule like that of female but 3 long aesthetascs added (Fig. 12d) (at points indicated by dots in Fig. 11a), aesthetasc on distal part of second segment 135 $\mu \mathrm{m}$ long, more than half length of entire antennule $(200 \mu \mathrm{m})$. Antenna as in female.

Labrum, mandible, maxillule, and maxilla like those of female. Maxilliped (Fig. 12g) 4 -segmented, resembling that of $A$. nasutus, above. Claw $104 \mu \mathrm{m}$.

Ventral area between maxillipeds and first pair of legs as in Fig. $12 \mathrm{~h}$.

Legs 1-4 like those of female. No sexual dimorphism.

Leg 5 (Fig. 12i) with free segment $35 \times 18 \mu \mathrm{m}$, ratio $1.94: 1$. Two terminal setae $21 \mu \mathrm{m}$ and $34 \mu \mathrm{m}$. Adjacent seta on body $52 \mu \mathrm{m}$.

Leg 6 represented by posteroventral flap on genital segment bearing 2 setae $26 \mu \mathrm{m}$ long (Fig. 12j).

Spermatophore not seen.

Color of living specimens as in female.

Etymology

The name compressus, Latin meaning compressed or drawn together, refers to the narrow prosome.

Remarks

Anchimolgus compressus resembles A. tenaus Humes, 1991a, from Acrhelia horrescens Dana on the Great Barrier Reef, in the following ways: the slender prosome; the dorsal indentation on the genital double-somite of the female; the form of the antenna, the mouthparts, and legs 1-5; and the lack of sexual dimorphism in the endopod of leg 1.

The new species differs from $A$. tanaus as follows: the greater body length (in the female, average $1.55 \mathrm{~mm}$, versus $1.25 \mathrm{~mm}$ in $A$. tenaus, in the male $1.26 \mathrm{~mm}$ versus $1.08 \mathrm{~mm}$ ), the ratio of length to width of the caudal ramus (in the female $3.35: 1$, in A. tenaus $10.6: 1$ ), the female genital double-somite without lateral indentations (in $A$. tenaus slightly indented), the intercoxal plate of leg 1 very narrow, and the free segment of leg 5 in the female with ratio of $2.61: 1$ (in $A$. tenaus $5.7: 1$ ).

From all congeners other than $A$. tenaus, the new species may be distinguished by the slender laterally compressed prosome thickened dorsoventrally.

\section{Anchimolgus moluccanus, new species}

(Figs. 13-16)

Type material. 3 우우, 6 송 from Galaxea fascicularis (L.), in $18 \mathrm{~m}$, Pulau Naira, Banda Islands, Moluccas, $04^{\circ} 32^{\prime} 12^{\prime \prime} \mathrm{S}, 129^{\circ} 53^{\prime} 40^{\prime \prime} \mathrm{E}, 2 \mathrm{v} 1975$. Holotype 우 (USNM 268453), allotype $\hat{\delta}$ (USNM 268454), and 4 paratypes ( 1 우, 3 송ㅅㅇ (268455) deposited in the National Museum of Natural History, Smithsonian Institution, Washington, D.C. Remaining paratypes, 1 우, 2 송ㅅㅇ, dissected, in the collection of the author.

Additional material. 1 f from Galaxea fascicularis, in $3 \mathrm{~m}$, Karang Mie, Weda Bay, eastern Halmahera, Moluccas, $00^{\circ} 20^{\prime} 02^{\prime \prime} \mathrm{N}, 128^{\circ} 26^{\prime} 00^{\prime \prime} \mathrm{E}, 19 \mathrm{v} 1975$.

Female 

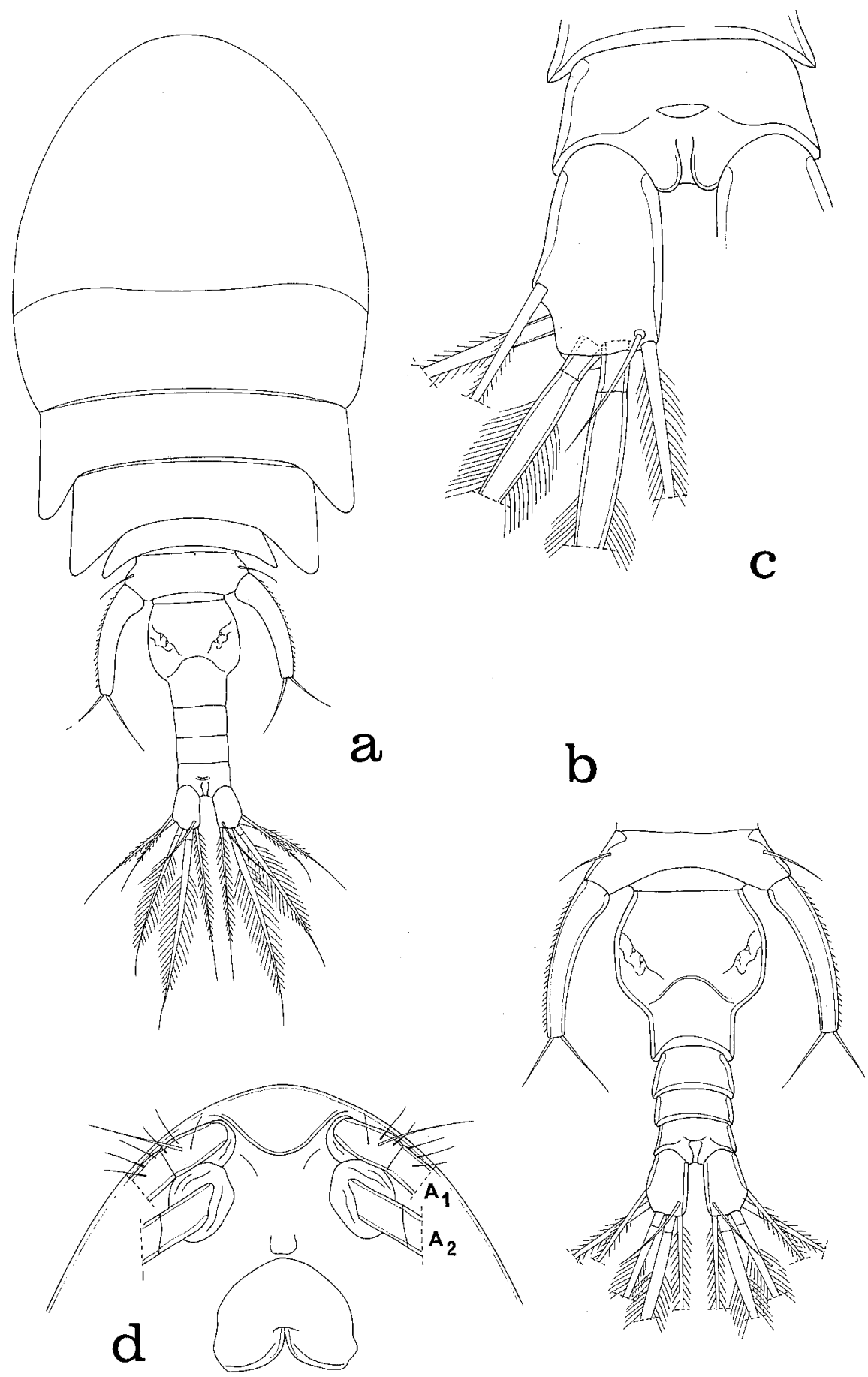

Fig. 13. Anchimolgus moluccanus, new species, female. a, body, dorsal (scale A); b, urosome, dorsal (B) ; c, anal somite and caudal ramus, dorsal (D) ; d, rostrum and labrum, ventral (C). $A_{1}=$ antennule, $\mathrm{A}_{2}=$ antenna. 

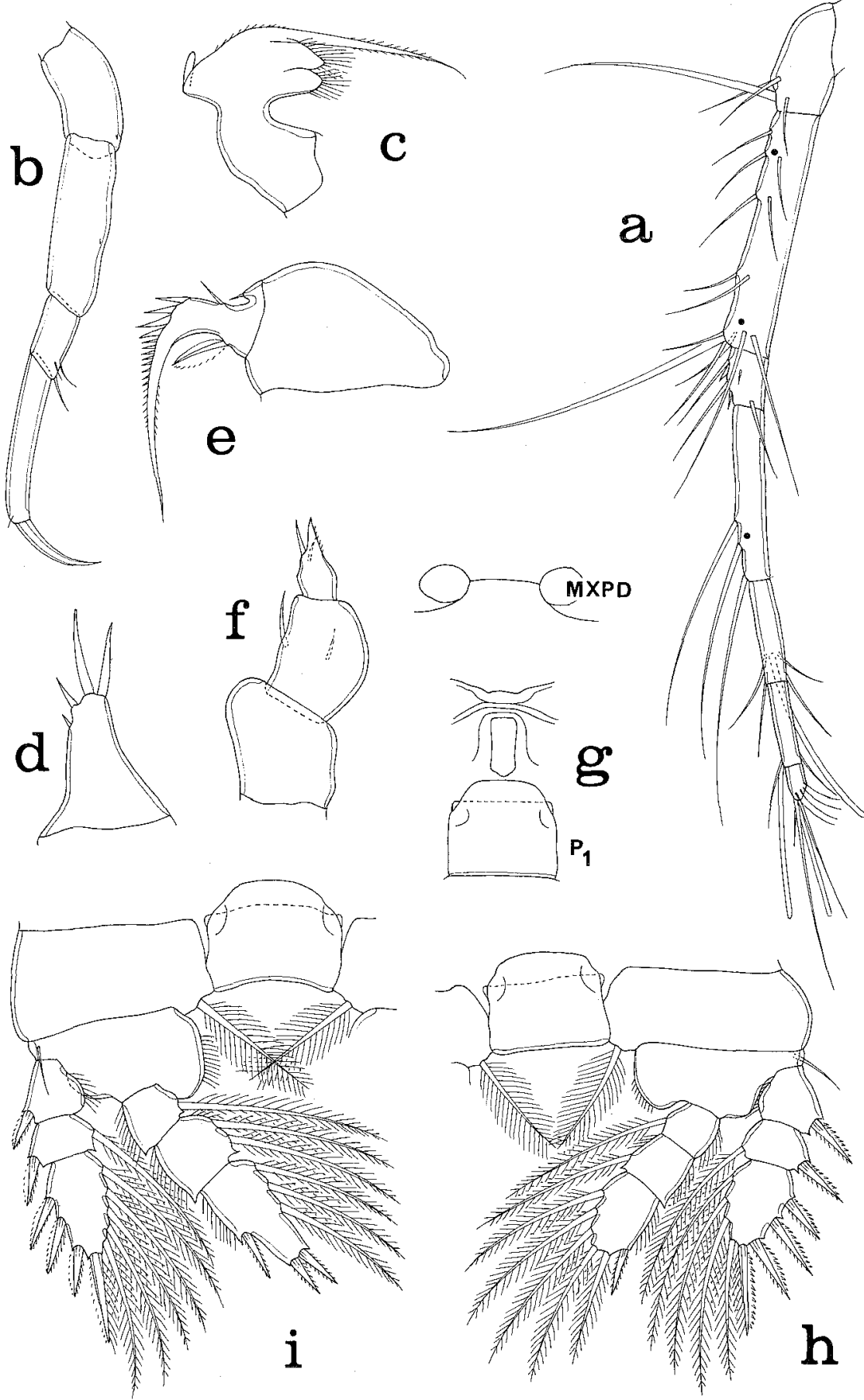

Fig. 14. Anchimolgus moluccanus, new species, female. a, antennule, with three dots indicating positions of three aesthetascs added in male, dorsal (scale G); b, antenna, antero-inner (G); $c$, mandible, posterior $(G)$; d, maxillule, posterior $(C)$; e, maxilla, posterior $(G)$; f, maxilliped, anterior (B) ; g, area between maxillipeds and first pair of legs, ventral $(\mathrm{G})$; h, leg 1 and intercoxal plate, anterior; i, leg 2 and intercoxal plate, posterior $(G)$ MXPD $=$ maxilliped, $P_{1}=\operatorname{leg} 1$. 
Body (Fig. 13a) with broad prosome. Length $1.10 \mathrm{~mm}(1.07-1.14 \mathrm{~mm})$ and greatest width $0.52 \mathrm{~mm}(0.50-0.56 \mathrm{~mm})$, based on 3 specimens. Greatest dorsoventral thickness $0.37 \mathrm{~mm}$. Somite bearing leg 1 separated from cephalosome by weak dorsal transverse suture. Epimera of that somite rounded, epimera of somites bearing legs $2-4$ pointed. Ratio of length to width of prosome $1.44: 1$. Ratio of length of prosome to that of urosome $1.88: 1$.

Somite bearing leg 5 (Fig. 13b) $62 \times 169 \mu \mathrm{m}$. Genital double-somite in dorsal view inversely bottle-shaped, length $161 \mu \mathrm{m}$. Anterior two-thirds expanded with slightly truncate lateral margins, width $150 \mu \mathrm{m}$. Posterior third with parallel margins, width $94 \mu \mathrm{m}$. Genital areas located dorsolaterally in anterior part of somite. Each genital area with 2 minute setae. Three postgenital somites from anterior to posterior $49 \times 83,34 \times 81$, and $36 \times 81 \mu \mathrm{m}$.

Caudal ramus (Fig. 13c) $75 \times 42 \mu \mathrm{m}$ (width taken at midregion), ratio $1.79: 1$, unornamented, slightly wider distally $(43 \mu \mathrm{m})$ than proximally $(36 \mu \mathrm{m})$. Outer lateral seta $170 \mu \mathrm{m}$, dorsal seta $46 \mu \mathrm{m}$, outermost terminal seta $190 \mu \mathrm{m}$, innermost terminal seta $200 \mu \mathrm{m}$, and 2 median terminal setae (inserted between small dorsal and ventral flanges) $242 \mu \mathrm{m}$ (outer) and $285 \mu \mathrm{m}$ (inner). All setae, except smooth dorsal seta, with lateral setules, those on 2 long median setae long.

Body surface without visible sensilla.

Egg sac not seen.

Rostrum (Fig. 13d) broadly rounded posteroventrally. Antennule (Fig. 14a) slender, 495 $\mu \mathrm{m}$ long. Lengths of its 7 segments : 26 (70 $\mu \mathrm{m}$ along anterior margin), 153, 34, 104, 53, 52, and $18 \mu \mathrm{m}$, respectively. Armature: $4,13,6,3,4+1$ aesthetasc, $2+1$ aesthetasc, and $7+1$ aesthetasc (positions of 3 aesthetascs added in male shown by dots). Segments 1 and 2 with long seta, that on segment 2 having length of $210 \mu \mathrm{m}$. All setae smooth. Antenna (Fig. 14b) slender, $340 \mu \mathrm{m}$ long including claw. Formula: 1, 1, 3, and $1 \mathrm{claw}+$ minute setule. Setae on first and second segments very small and obscure. Fourth segment elongate, $112 \mu \mathrm{m}$ along outer side, $94 \mu \mathrm{m}$ along inner side, and width $15.5 \mu \mathrm{m}$, claw slender, $55 \mu \mathrm{m}$.

Labrum (Fig. 13d) with 2 broad posteroventral lobes. Mandible (Fig. 14c) apparently with only 1 digitiform lobe on convex side of base. Paragnath not seen. Maxillule (Fig. 14d) small lobe with 4 setae. Maxilla (Fig. 14e) with second segment having prominent proximal outer setule. Maxilliped (Fig. 14f) resembling that of congeners.

Ventral area between maxillipeds and first pair of legs (Fig. 14g) protuberant in lateral view.

Legs 1-4 (Figs. 14h,i, 15a,b) segmented and armed as in Anchimolgus nasutus, above, with same formula for spines and setae. Leg 4 (Fig. 15b) with smooth inner coxal seta short, 13 $\mu \mathrm{m}$. Exopod $172 \mu \mathrm{m}$. Endopod with first segment $16 \times 28 \mu \mathrm{m}$, its inner plumose seta $47 \mu \mathrm{m}$; second segment $64 \times 22 \mu \mathrm{m}$, ratio $2.90: 1$, its 2 terminal finely barbed spines $41 \mu \mathrm{m}$ and $70 \mu \mathrm{m}$.

Leg 5 (Fig. 13b) with elongate free segment (Fig. 15c) $173 \mu \mathrm{m}$ long, width $31 \mu \mathrm{m}$ at slight proximal inner expansion, $15.5 \mu \mathrm{m}$ at distal end. Short spines along inner margin.

Leg 6 represented by 2 very small setae on genital area (Fig. 13b).

Color of living specimens in transmitted light opaque gray to tan, eye red. Male

Body (Fig. 15d) with prosome slightly less broadened than in female. Length $0.88 \mathrm{~mm}(0$. $86-0.94 \mathrm{~mm})$ and greatest width $0.32 \mathrm{~mm}(0.31-0.34 \mathrm{~mm})$, based on 5 specimens. Greatest dorsoventral thickness $0.30 \mathrm{~mm}$. Ratio of length to width of prosome $1.78: 1$. Ratio of length of prosome to that of urosome $1.61: 1$.

Somite bearing leg 5 (Fig. 15e) $39 \times 102 \mu \mathrm{m}$. Genital somite elongate, $200 \mu \mathrm{m}$ long including leg 6 and $174 \mu \mathrm{m}$ wide, ratio $1.15: 1$. In lateral view (Fig. 15f), dorsoventral thickness 117 $\mu \mathrm{m}$. Four postgenital somites from anterior to posterior $18 \times 52,18 \times 52,13 \times 57$, and $17 \times 60$ $\mu \mathrm{m}$. 

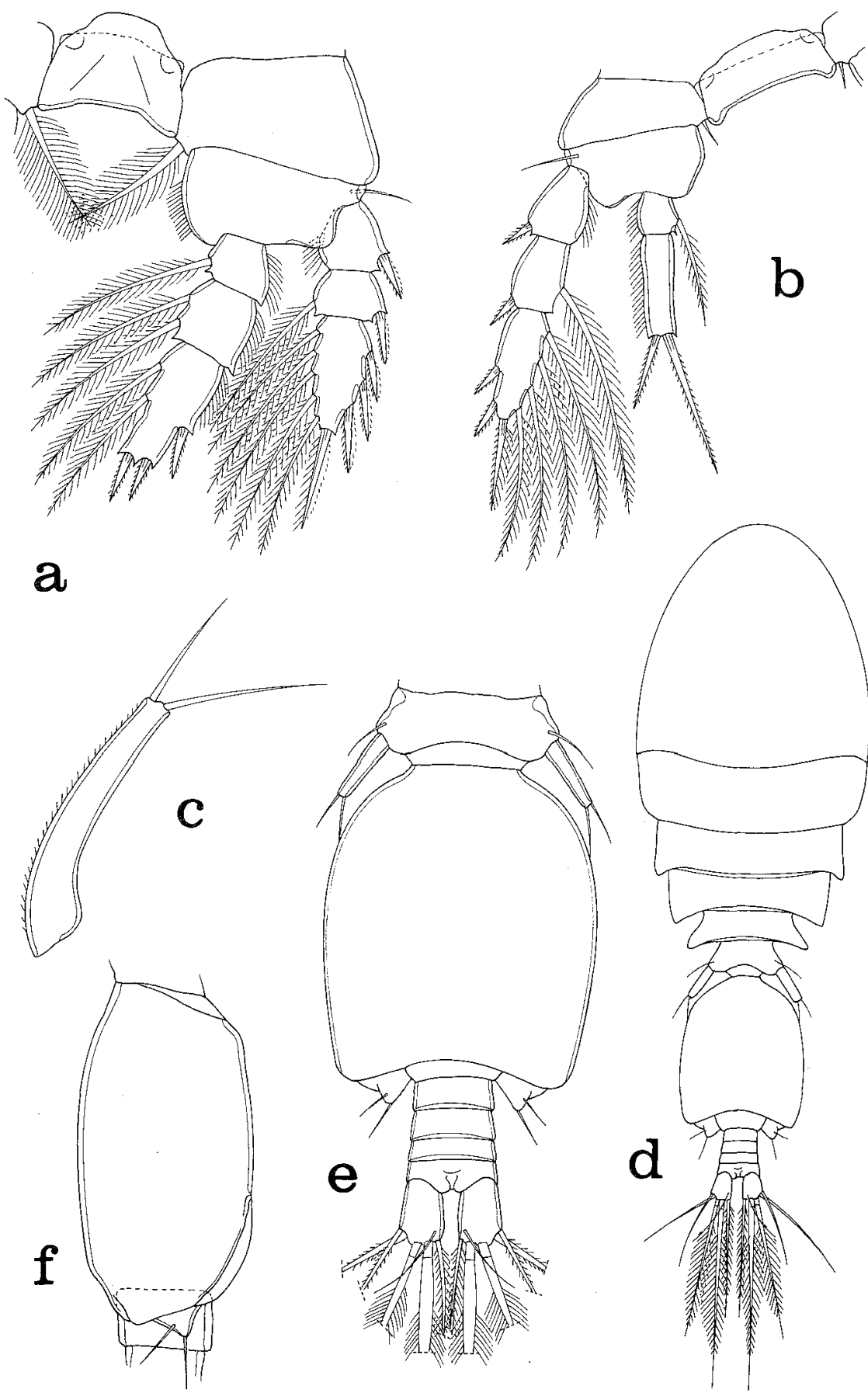

Fig. 15. Anchimolgus moluccanus, new species. Female. a, leg 3 and intercoxal plate, anterior (scale $\mathrm{G})$; b, leg 4 and intercoxal plate, posterior $(\mathrm{G})$; c, free segment of leg 5 , dorsal $(G)$. Male. d, body, dorsal (A); e, urosome, dorsal (G); f, genital somite, lateral (G). 


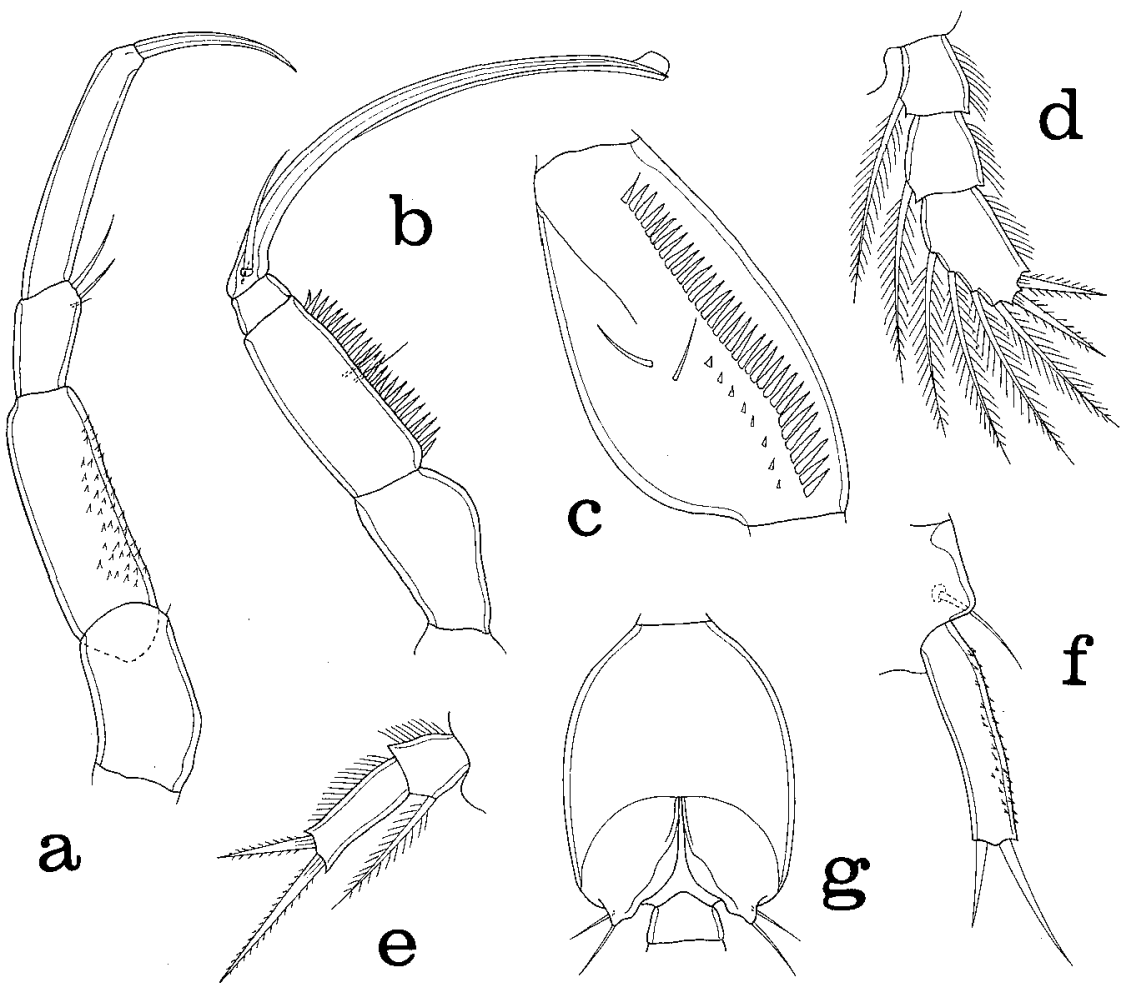

Fig. 16. Anchimolgus moluccanus, new species, male. a, antenna, postero-outer (scale B) ; b, maxilliped, postero-inner $(\mathrm{G})$; c, second segment of maxilliped, inner $(\mathrm{C})$; d, endopod of leg 1, posterior (B) ; e, endopod of leg 4, posterior (B) ; f, leg 5 , ventral (C) ; g, genital somite showing leg 6 , ventral (G).

Caudal ramus (Fig. 15e) resembling that of female, but smaller, $47 \times 31 \mu \mathrm{m}$, ratio $1.55: 1$.

Rostrum as in female. Antennule like that of female, but 3 aethetascs added, 2 on second segment and 1 on fourth segment, at locations shown by dots in Fig. 14a. Antenna (Fig. 16a) showing sexual dimorphism in having small spines on second segment, otherwise like that of female.

Labrum, mandible, maxillule, and maxilla like those of female. Maxilliped (Fig. 16b) with second segment bearing tusual 2 setae and 1 long row of large spines and 1 short row of 7 or 8 small spines (Fig. 16c). Claw $235 \mu \mathrm{m}$ long, having conspicuous terminal lamella and bearing 2 very unequal proximal setae, smaller seta minute and obscure.

Ventral area between maxillipeds and first pair of legs as in female.

Legs 1-4 segmented and armed as in female except for sexual dimorphism in endopod of leg 1 (Fig. 16d), with formula $0-1 ; 0-1$; I,I,4. Endopod of leg 4 (Fig. 16e) with second segment slightly smaller than in female, $43 \times 15.5 \mu \mathrm{m}$, ratio $2.77: 1$.

Leg 5 (Fig. 16f) with free segment $52 \times 13 \mu \mathrm{m}$, smaller than in female, ratio $4: 1$. Its 2 terminal setae $21 \mu \mathrm{m}$ and $33 \mu \mathrm{m}$. Minute spines along outer edge of free segment.

Leg 6 (Fig. $16 \mathrm{~g}$ ) posteroventral flap on genital segment bearing 2 setae.

Spermatophore not seen.

Color of living specimens as in female. 


\section{Etymology}

The specific name moluccanus, a combination of Moluccas and the Latin suffix -anus, meaning pertaining to or belonging to, alludes to the area where the specimens were found.

Remarks

Anchimolgus moluccanus may be recognized by the elongate fourth segment of the antenna, approximately equal in length to the second segment. In all 20 congeners, the fourth segment is distinctly shorter than the second segment. The shape of the caudal ramus is also distinctive. In all other species the caudal ramus has subparallel sides, and is not broadened distally as in the new species. The shape of the genital double-somite in the female resembles that of Anchimolgus prolixipes (Humes \& Ho, 1968), A. convexus Humes, 1978, and A. nasutus, new species, above, but in these species the caudal ramus is longer (ratios of length to width $2.65: 1,2.33: 1$, and $2.72: 1$, respectively) than in the new species.

\section{Anchimolgus abbreviatus Humes, 1991}

Material examined. 8 우우, 5 소 from Galaxea fascicularis (L.), in $2 \mathrm{~m}$, Ricaudy Reef, near Noumea, New Caledonia, $22^{\circ} 19^{\prime} 00^{\prime \prime} \mathrm{S}, 166^{\circ} 26^{\prime} 44^{\prime \prime} \mathrm{E}$, 25 vi 1971.

Remarks

This species has been known until now only from Acrhelia horrescens Dana at Big Broadhurst Reef, on the Great Barrier Reef, northeastern Australia (Humes, 1991).

\section{Anchimolgus contractus Humes, 1979}

Material examined. 30 우우, 21 송ㅅㅇ from Galaxea fascicularis (L.), in $2 \mathrm{~m}$, Ricaudy Reef, near Noumea, New Caledonia, $22^{\circ} 19^{\prime} 00^{\prime \prime} \mathrm{S}, 166^{\circ} 26^{\prime} 44^{\prime \prime} \mathrm{E}$, 25 vi 1971.

Remarks

This species has previously been found with Galaxea fascicularis at Karang Mie, Halmahera, and at Banda, in the Moluccas (Humes, 1979).

\section{Anchimolgus tenaus Humes, 1991}

Material examined. 54 우우, 90 . 令令, from Galaxea fascicularis (L.), var. minima Chevalier, in $2 \mathrm{~m}$, Ricaudy Reef, near Noumea, New Caledonia, 22 $19^{\prime} 00^{\prime \prime} \mathrm{S}, 166^{\circ} 26^{\prime} 44^{\prime \prime} \mathrm{E}, 25$ vi 1971.

\section{Remarks}

This species has been previously found only with Acrhelia horrescens Dana at Big Broadhurst Reef, Great Barrier Reef, northeastern Australia (Humes, 1991a).

A comparison of the specimens from New Caledonia with paratypes of Anchimolgus tenaus shows basic similarity. The New Caledonian specimens, however, are larger, with the body length of the female being $1.42 \mathrm{~mm}(1.31-1.46 \mathrm{~mm})$, compared to $1.25 \mathrm{~mm}(1.24-1.33 \mathrm{~mm})$ in the Australian material ; the body length of the male $1.25 \mathrm{~mm}(1.21-1.32 \mathrm{~mm})$ versus 1.08 $\mathrm{mm}(1.04-1.11 \mathrm{~mm})$. The body parts reflect this difference in body size in the New Caledonian A. tenaus, where, for example, the female genital double-somite is $260 \times 172 \mu \mathrm{m}$ (ratio 1.52 : 1 ), the female caudal ramus is $300 \times 24 \mu \mathrm{m}$ (ratio $1.05: 1$ ), and the claw of the male maxilliped is $198 \mu \mathrm{m}$. The expanded convex side of the mandible bears three minute lobes, not one as shown in Humes (1991, fig. 23b). The presence of three small lobes has been verified by an examination of paratypes. [The dissections of paratypes, made in November 1990, prepared according to the method of Humes and Gooding (1964), and completely dry, were restored to nearly original condition by the addition of a film of lactic acid.]

Although the specimens from Galaxea are larger than those from Acrhelia, they conform 
in other respects. Galaxea is a new host for A. tenaus. The two coral genera Galaxea and Acrhelia are related and belong to the same family, the Oculinidae (see Veron, 1986). It is not surprising, perhaps, that the same species of Anchimolgus should occur on both genera, and that there is a small size difference in the copepods from the two corals.

Key to females of the genus Anchimolgus

(A. breviarius Humes, 1995, is not included, since only males are known.)

1. Caudal ramus with length to width ratio at least $3: 1 \ldots \ldots \ldots \ldots \ldots \ldots \ldots \ldots$

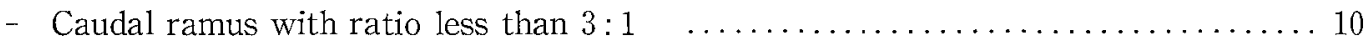

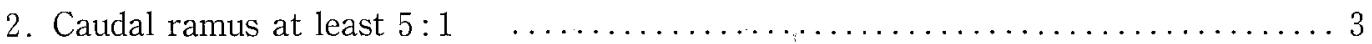

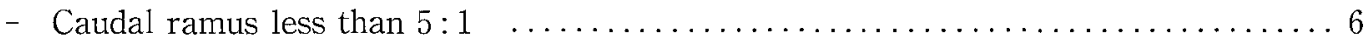

3. Genital double-somite constricted at midregion, hourglass-shaped; caudal ramus with outer lateral seta located far subterminally ............. A. exsertus Humes, 1991

- Genital double-somite not greatly constricted at midregion, not hourglass-shaped ; caudal ramus with outer lateral seta inserted terminally or a little subterminally $\ldots 4$

4. Free segment of leg 5 long, $114 \times 20 \mu \mathrm{m}$, ratio $5.7: 1$; genital double-somite elongate, notched laterally ; caudal ramus very long, $10.6: 1 \quad \ldots \ldots \ldots$. tenaus Humes, 1991

- Free segment of leg 5 shorter, $3: 1$ or less; genital double-somite broad, not notched

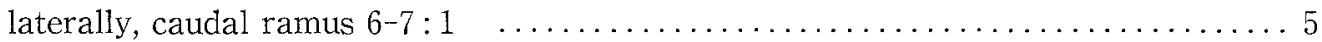

5. Body length $1.89 \mathrm{~mm}(1.73-2.00 \mathrm{~mm})$; caudal ramus $220 \times 36 \mu \mathrm{m}$, ratio $6: 1$

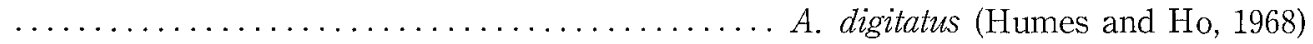

- Body length $1.28 \mathrm{~mm}(1.26-1.36 \mathrm{~mm})$; caudal ramus $148 \times 21 \mu \mathrm{m}, 7.05: 1$

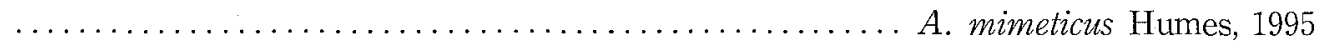

6. Body length $2.16 \mathrm{~mm}(2.11-2.19 \mathrm{~mm})$; free segment of leg 5 massive, $130 \times 65 \mu \mathrm{m}, 2.89: 1$

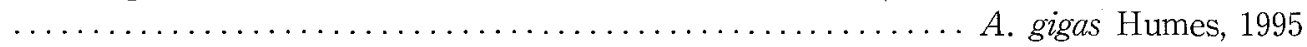
Body length less than $1.85 \mathrm{~mm}$; free segment of leg 5 elongate, at least $3.97: 1 \ldots 7$

7. Free segment of leg 5 short, smooth $2.6: 1$; genital double-somite barrel-shaped, not noticeably tapered posteriorly $\ldots \ldots \ldots \ldots \ldots \ldots \ldots \ldots$. compressus, new species - Free segment of leg 5 long, at least $3.97: 1$, ornamented with spinules; genital doublesomite tapered posteriorly or notched laterally $\ldots \ldots \ldots \ldots \ldots \ldots \ldots \ldots \ldots$

8. Rostrum elongate, slender, nasiform ; dorsal seta adjacent to free segment of leg 5 very long, longer than free segment $\ldots \ldots \ldots \ldots \ldots \ldots \ldots \ldots$. . nasutus, new species Rostrum not elongate or nasiform; dorsal seta adjacent to free segment of leg 5 not

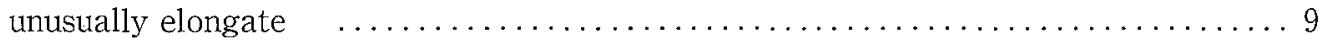

9. Antenna 4-segmented; genital double-somite widest at midregion, in front of lateral indentations $\quad \ldots \ldots \ldots \ldots \ldots \ldots \ldots \ldots \ldots \ldots \ldots \ldots \ldots \ldots$. latens Humes, 1973

- Antenna 3-segmented ; genital double-somite widest in anterior fourth, tapered poster-

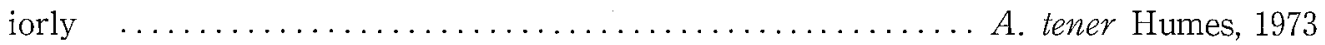

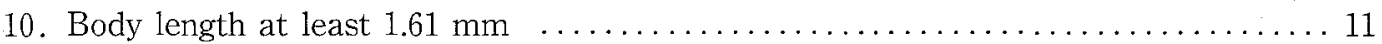

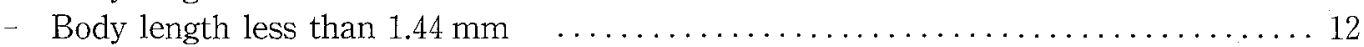

11. Genital double-somite slender, $1.4: 1$; free segment of leg $5180 \times 44 \mu \mathrm{m}, 4.1: 1$; ornamented with spinules ...................... abbreviatus Humes, 1991

- Genital double somite about as wide as long ; free segment of leg $5147 \times 45 \mu \mathrm{m}, 2.27: 1$,

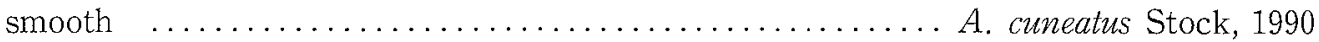

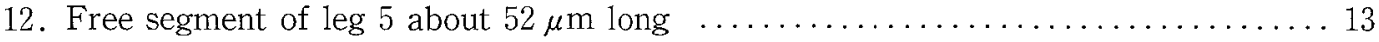

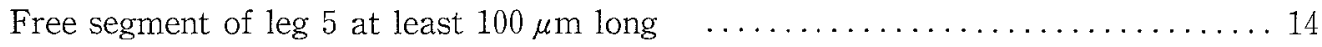

13. Genital double-somite tapered posteriorly; fourth segment of antenna shorter than third segment $\ldots \ldots \ldots \ldots \ldots \ldots \ldots \ldots \ldots \ldots \ldots \ldots$. conformatus Humes, 1995

- Genital double-somite laterally indented; fourth segment of antenna longer than third 
segment

A. contractus Humes, 1979

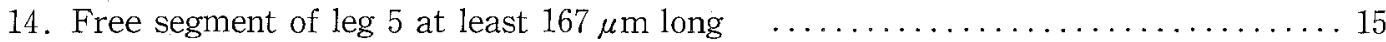

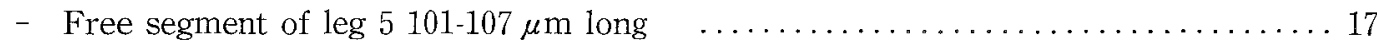

15. Free segment of leg $5203 \mu \mathrm{m}$ long, longer than genital double-somite ; caudal ramus with ratio $2.65: 1 \quad \ldots \ldots \ldots \ldots \ldots \ldots \ldots \ldots \ldots$. prolixipes (Humes and Ho, 1968)

- Free segment of leg $5167-172 \mu \mathrm{m}$ long, shorter than genital double-somite; caudal ramus

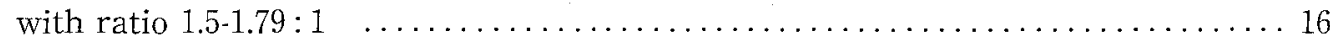

16. Body length $1.40 \mathrm{~mm}(1.36-1.43 \mathrm{~mm})$; sides of genital double-somite slightly truncate; third and fourth segments of antenna nearly equal ....... A. notatus Humes, 1978

- Body length $1.10 \mathrm{~mm}(1.07-1.14 \mathrm{~mm})$; sides of genital double-somite rounded; fourth segment of antenna 3 times longer than third segment .. A. moluccanus, new species

17. Genital double-somite elongate, slender ; third segment of antenna about 3 times longer than fourth segment, both segments unusually slender ...... A. orectus Humes, 1978

- Genital double-somite shorter, broad; third and fourth segments of antenna not unusu-

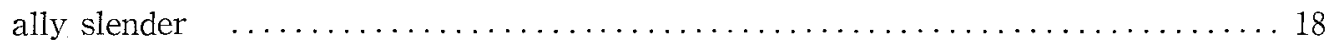

18. Third segment of antenna with convex outer margin; body length $0.98 \mathrm{~mm}(0.88-0.99$ $\mathrm{mm})$; caudal ramus $2.88: 1 \ldots \ldots \ldots \ldots \ldots \ldots \ldots$. convexus Humes, 1978

- Third segment of antenna with sides subparallel ; body length $1.01 \mathrm{~mm}$ or more ; caudal

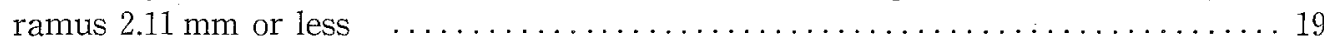

19. Body length $1.21 \mathrm{~mm}(1.23-1.31 \mathrm{~mm})$; third segment of exopod of leg 4 with formula III, I,5; genital double-somite anteriorly rounded $\ldots \ldots \ldots \ldots \ldots$. pandus Humes, 1978 Body length $1.09 \mathrm{~mm}$ (1.01-1.22 $\mathrm{mm}$ ) ; third segment of exopod of leg 4 with formula II, I,5; genital double-somite with anterior "shoulders" ...... A. punctilis Humes, 1978

\section{Clamocus spinifer Humes, 1979}

Material examined. 4 우우, 10 용 from Galaxea fascicularis (L.), in 2 m, Ricaudy Reef, near Noumea, New Caledonia, 22 $19^{\prime} 00^{\prime \prime} \mathrm{S}, 166^{\circ} 26^{\prime} 44^{\prime \prime} \mathrm{E}$, 25 vi 1971.

Remarks

This species has been reported only from Galaxea fascicularis at Karang Mie, Halmahera (Humes, 1979).

\section{Karanges galaxeanus Humes, 1979}

Material examined. 3 우우 from Galaxea fascicularis (L.), in $18 \mathrm{~m}$, Pulau Naira, Banda Islands, Moluccas. $04^{\circ} 22^{\prime} 12^{\prime \prime} \mathrm{S}, 129^{\circ} 53^{\prime} 40^{\prime \prime} \mathrm{E}, 2 \mathrm{v} .1975$.

Remarks

This species has been reported only from Galaxea fascicularis at Karang Mie, Halmahera (Humes, 1979).

\section{Karanges hypsorophus Humes, 1979}

Material examined. 1 우 from Galaxea fascicularis (L.), in $2 \mathrm{~m}$, Ricaudy Reef, near Noumea, New Caledonia, $22^{\circ} 19^{\prime} 00^{\prime \prime} \mathrm{S}, 166^{\circ} 26^{\prime} 44^{\prime \prime} \mathrm{E}, 25$ vi 1971.

Remarks

This species has thusfar been known only from Galaxea fascicularis at Karang Mie, Halmahera (Humes, 1979). 


\section{Genus Xarifia Humes, 1960}

\section{Xarifa exserens Humes, 1985}

Remarks

This species is known only from the type locality, Karang Mie, Halmahera, Moluccas, where it is parasitic in Galaxea fascicularis (L.) (see Humes, 1985).

\section{Xarifia sp.}

Remarks

An unidentified species of Xarifia was found by Humes (1985: 584) in Galaxea astreata (Lamarck) at Nosy Bé, northwestern Madagascar.

Order Siphonostomatoida Thorell, 1859

Family Asterocheridae Giesbrecht 1899

\section{Genus Hetairosyna Humes, 1991}

\section{Hetairosyna galaxeae, new species}

(Figs. 17-19)

Type material. 6 우 우 from Galaxea fascicularis (L.), in $3 \mathrm{~m}$, Karang Mie, Weda Bay, Halmahera, Moluccas, $00^{\circ} 20^{\prime} 07^{\prime \prime} \mathrm{N}, 128^{\circ} 25^{\prime} 00^{\prime \prime} \mathrm{E}, 19 \mathrm{v} 1975$. Holotype (USNM 268456) and 4 paratypes (USNM 268457) deposited in the National Museum of Natural History, Smithsonian Institution, Washington, D.C. Remaining paratype, dissected, in the collection of the author.

Female

Body (Fig. 17a) with broad prosome, somewhat tapered anteriorly. Length $0.92 \mathrm{~mm}(0.86$ $-0.98 \mathrm{~mm})$ and greatest width $0.52 \mathrm{~mm}(0.51-0.54 \mathrm{~mm})$, based on 5 specimens. Greatest dorsoventral thickness $0.35 \mathrm{~mm}$. Somite bearing first pair of legs fused with cephalosome. Epimera of somites bearing legs 1 and 2 slightly pointed, those of legs 3 and 4 rounded. Ratio of length to width of prosome $1.27: 1$. Ratio of length of prosome to that of urosome 2.21 : 1.

Somite bearing leg 5 (Fig. 17b) $75 \times 143 \mu \mathrm{m}$. Genital double-somite $112 \times 132 \mu \mathrm{m}$, wider than long, ratio $0.85: 1$, broadest in anterior half, tapered posteriorly. Genital areas located dorsolaterally near level of expanded portion of segment. Each genital area (Fig. 17c) with 2 minute setae and very small seta on pedicel. Usual row of long setules on both sides near midregion of somite. Two postgenital somites from anterior to posterior $42 \times 74 \mu \mathrm{m}$ and $36 \times$ $70 \mu \mathrm{m}$.

Caudal ramus (Fig. 17c) short, $25 \times 31 \mu \mathrm{m}$, wider than long, ratio $0.81: 1$. Outer lateral seta, displaced dorsally, $90 \mu \mathrm{m}$, dorsal seta $68 \mu \mathrm{m}$, outermost terminal seta $187 \mu \mathrm{m}$, innermost terminal seta $164 \mu \mathrm{m}$, and 2 median terminal setae $385 \mu \mathrm{m}$ (outer) and $475 \mu \mathrm{m}$ (inner). All setae with lateral setules.

Dorsal surface of body without visible sensilla, but urosome with many small surficial scales.

Egg sac unknown.

Rostral area weakly developed (Fig. 17e). Antennule (Fig. 18a) $360 \mu \mathrm{m}$ long, 19-segmented, though last 2 segments incompletely separated. Lengths of segments : 21 (39 $\mu \mathrm{m}$ along anterior margin), 15, 11, 11, 11, 12, 12, 14, 10, 17, 22, 22, 21, 21, 25, 27, 29, 13, and $33 \mu \mathrm{m}$, respectively. Armature : 2, 2, 2, 2, 2, 2, 2, 2, 6, 1+1 small spine, 2, 2, 2, 2, 2, 2, 2+1 aesthetasc, 3 , and 7 . All setae smooth. First segment with small spines along convex margin. Antenna 


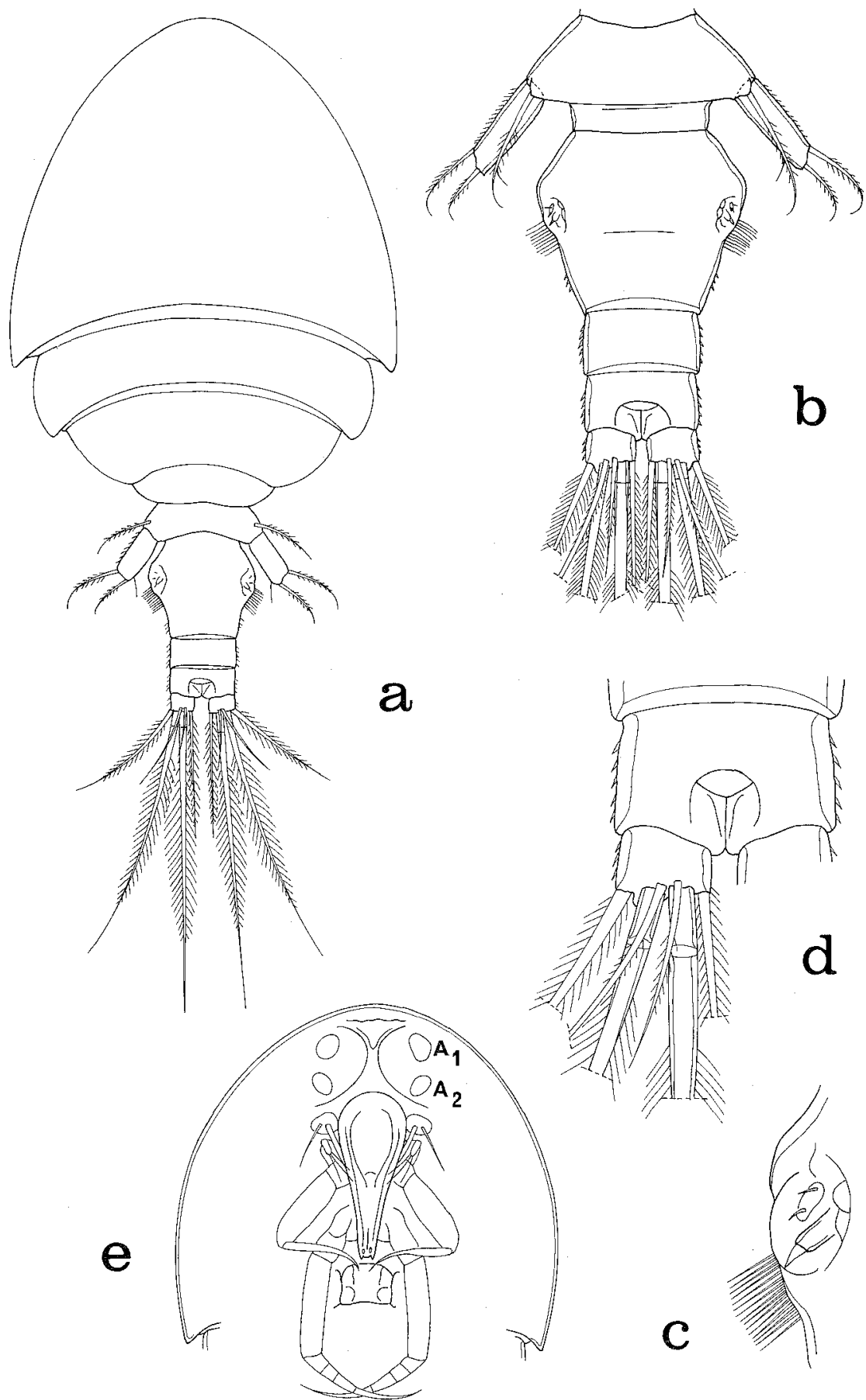

Fig. 17. Hetairosyna galaxeae, new species, female. a, body, dorsal (scale A); b, urosome, dorsal (G); c, genital area, dorsal (D) ; d, anal somite and caudal ramus, dorsal (C) ; e, cephalosome, ventral (A). $\mathrm{A}_{1}=$ antennule, $\mathrm{A}_{2}=$ antenna. 


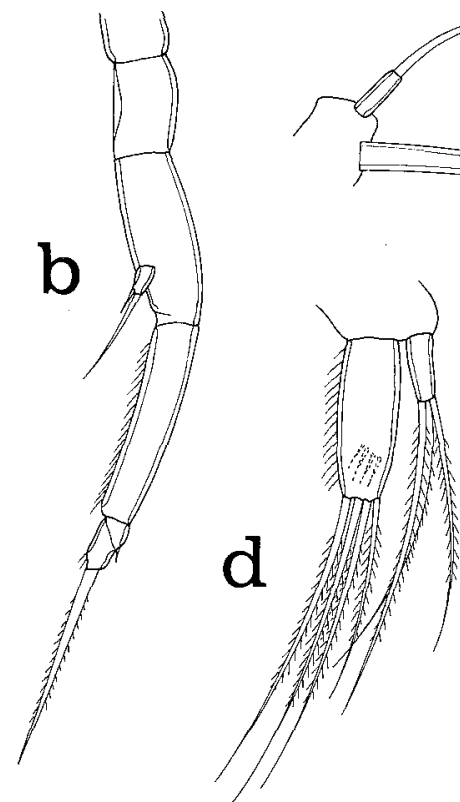

\section{C}
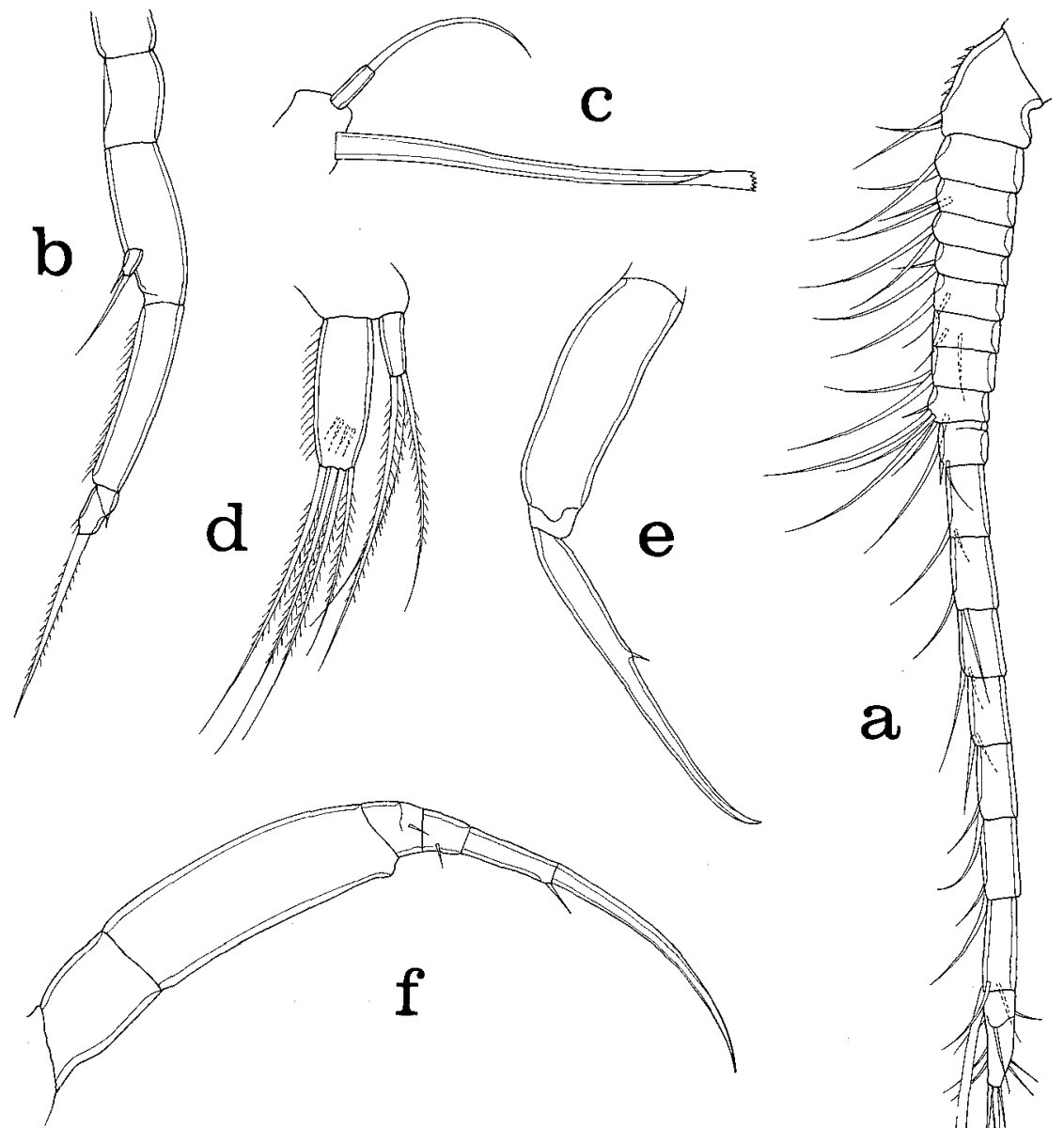

a
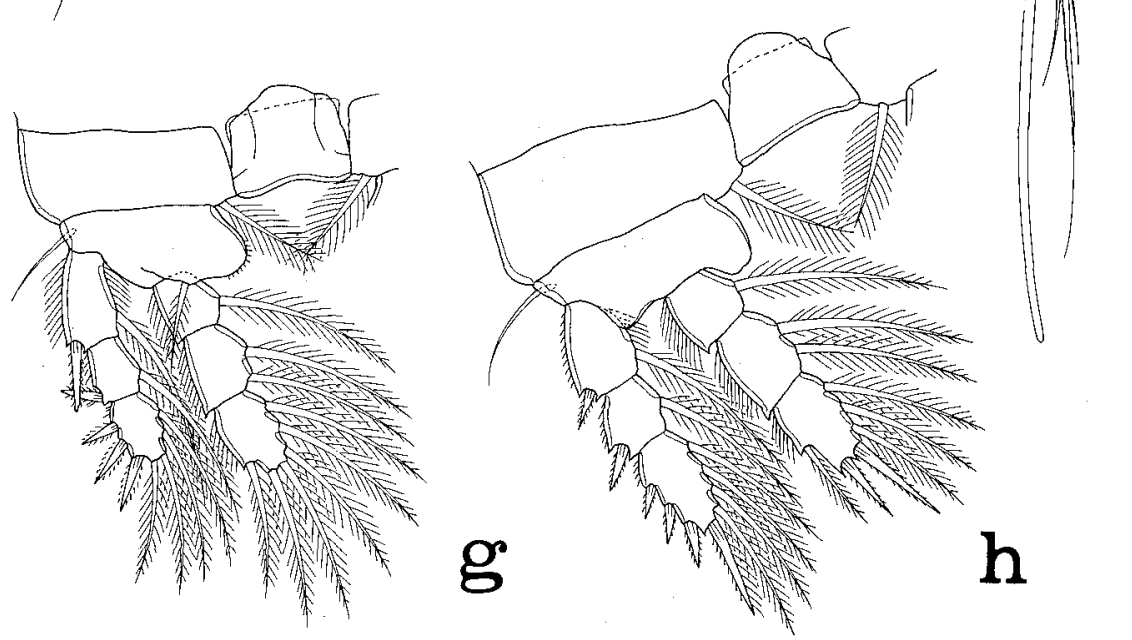

Fig. 18. Hetairosyna galaxeae, new species, female. a, antennule, antero-outer (scale B); b, antenna, posterior (B) ; c, mandible, posterior (G) ; d, maxillule, posterior (B) ; e, maxilla, posteroventral (B) ; f, maxilliped, posterior (B) ; g, leg 1 and intercoxal plate, anterior $(\mathrm{G})$; h, leg 2 and intercoxal plate, anterior $(G)$. 

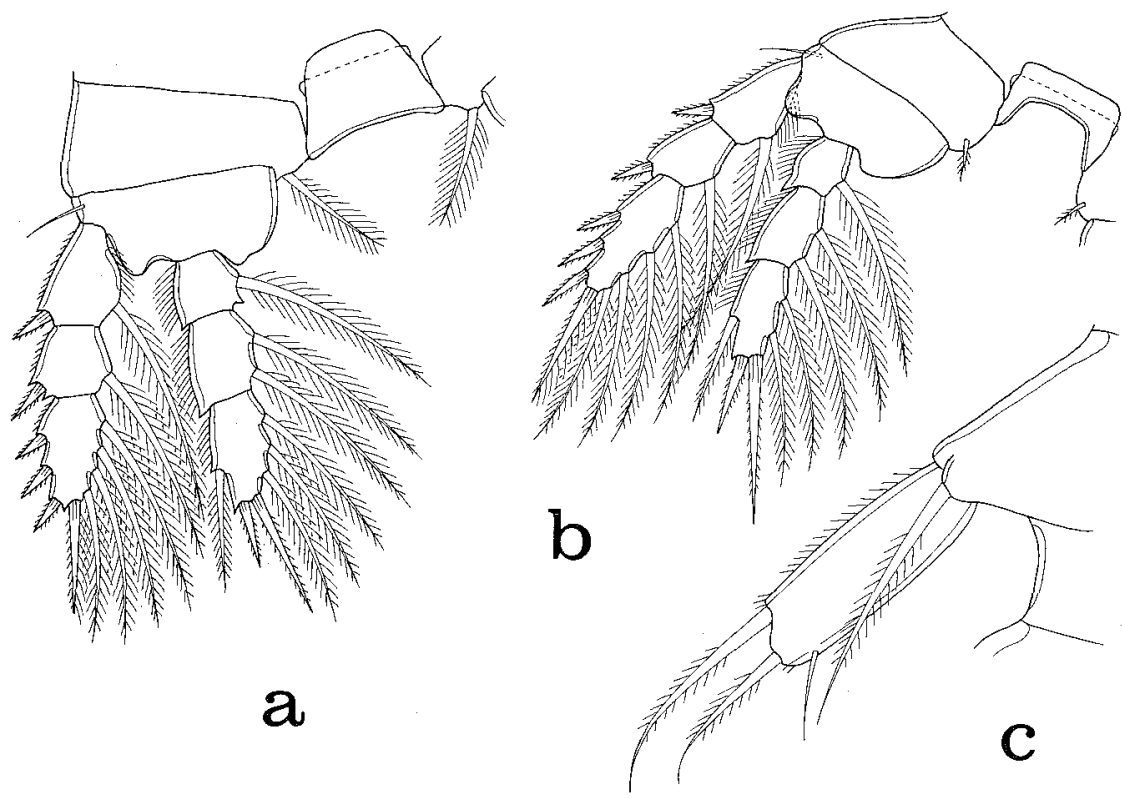

Fig. 19. Hetairosyna galaxeae, new species, female. a, leg 3 and intercoxal plate, posterior (scale G); b, leg 4 and intercoxal plate, anterior $(\mathrm{G})$; c, leg 5 , dorsal (C).

(Fig. 18b) $4^{4-s e g m e n t e d, ~ 237 ~} \mu \mathrm{m}$ long. Exopod sma11, 7.7x4.5 $\mu \mathrm{m}$. First endopodal segment with setules along outer margin. Terminal finely barbed seta $64 \mu \mathrm{m}$.

Siphon elongate (Fig. 17e), $225 \mu \mathrm{m}$, reaching nearly to intercoxal plate of leg 1 . Mandible (Fig. 18c) with long slender blade $190 \mu \mathrm{m}$ and 1 -segmented palp plus its seta $92 \mu \mathrm{m}$. Maxillule (Fig. 18d) and maxilla (Fig. 18e) similar to those of $H$. sororia Humes, 1991. Maxilliped (Fig. 18f) also similar to that of $H$. sororia, but claw longer, $130 \mu \mathrm{m}$.

Ventral region between maxillipeds and first pair of legs protuberant as in H. sororia (see Humes, 1991, fig. 15c).

Legs 1-4 (Figs. 18g,h, 19a,b) similar in general respects to those of $H$. sororia. Formula for armature:

$\begin{array}{lllllllll}\mathrm{P}_{1} & \text { coxa } & 0-1 & \text { basis } & 1-\mathrm{I} & \exp & \mathrm{I}-1 ; & \mathrm{I}-1 ; & \mathrm{III}, 4 \\ & & & & & \operatorname{enp} & 0-1 ; & 0-2 ; & 1,5 \\ \mathrm{P}_{2} & \operatorname{coxa} & 0-1 & \text { basis } & 1-0 & \exp & \mathrm{I}-1 ; & \mathrm{I}-1 ; & \mathrm{III}, \mathrm{I}, 4 \\ & & & & & \operatorname{enp} & 0-1 ; & 0-2 ; & 1, \mathrm{II}, 3 \\ \mathrm{P}_{3} & \operatorname{coxa} & 0-1 & \text { basis } 1-0 & \exp & \mathrm{I}-1 ; & \mathrm{I}-1 ; & \mathrm{III}, \mathrm{I}, 4 \\ & & & & & \operatorname{enp} & 0-1 ; & 0-2 ; & 1, \mathrm{II}, 3 \\ \mathrm{P}_{4} & \operatorname{coxa} & 0-1 & \text { basis } & 1-0 & \exp & \mathrm{I}-1 ; & \mathrm{I}-1 ; & \mathrm{III}, \mathrm{I}, 4 \\ & & & & & \text { enp } 0-1 ; & 0-2 ; & 1, \mathrm{II}, 2\end{array}$

Leg 1 (Fig. 18g) with inner setiform spine on basis $37 \mu \mathrm{m}$. Exopod with long setules on outer margins of first 2 segments. Leg 4 (Fig. 19b) with inner coxal seta short, $22 \mu \mathrm{m}$. Two terminal spines on exopod $40 \mu \mathrm{m}$ and $77 \mu \mathrm{m}$.

Leg 5 (Fig. 19c) with free segment elongate, $60 \times 21 \mu \mathrm{m}$, ratio $2.86: 1$. Two terminal plumose setae from outer to inner $65 \mu \mathrm{m}$ and $40 \mu \mathrm{m}$. Subterminal hyaline seta $25 \mu \mathrm{m}$. Dorsal plumose seta adjacent to insertion of free segment $75 \mu \mathrm{m}$. Outer margin of free segment with small setules.

Leg 6 represented by setae on genital area (Fig. 17c). 
Color of living specimens in transmitted light opaque gray, eye red.

Male. Unknown.

Etymology

The name of the new species is derived from Galaxea, the genus of the host coral.

Remarks

Hetairosyna galaxeae is close to $H$. sororia, a copepod associated with species of Montipora in Madagascar, northeastern Australia, New Caledonia, and Ceram in the Moluccas (Humes, 1971). The new species may be differentiated from $H$. sororia as follows: (1) epimera of somites bearing legs 1-4 less pointed; (2) genital double-somite wider than long, ratio $0.85: 1$, with sides expanded (versus subquadrate, $0.98: 1$, with sides only slightly convex) ; (3) antenna with terminal seta (claw) $64 \mu \mathrm{m}$ long, barbed (versus $115 \mu \mathrm{m}$, smooth); (4) mandible with length of palp plus its seta $92 \mu \mathrm{m}$ (versus $200 \mu \mathrm{m}$ ) ; (5) claw of maxilliped $130 \mu \mathrm{m}$ (versus $104 \mu \mathrm{m}$ ) : (6) inner spine on basis $37 \mu \mathrm{m}$ (versus $52 \mu \mathrm{m}$ ); (7) terminal segment of endopod of leg 1 truncate (versus pointed); and (8) free segment of leg $560 \times 21 \mu \mathrm{m}$, ratio $2.86: 1$ (versus $47 \times 23 \mu \mathrm{m}$, ratio $2.04: 1$ ).

\section{Hetairosyna wedensis, new species}

(Figs. 20-22)

Type material. 17 우우 from Galaxea fascicularis (L.), in $3 \mathrm{~m}$, Karang Mie, Weda Bay, eastern Halmahera, Moluccas, $00^{\circ} 20^{\prime} 07^{\prime \prime} \mathrm{N}, 128^{\circ} 25^{\prime} 00^{\prime \prime} \mathrm{E}$, $19 \mathrm{v} 1975$. Holotype (USNM 268458) and 12 paratypes (USNM 268459) deposited in the National Museum of Natural History, Smithsonian Institution, Washington, D.C. Remaining paratypes, dissected, in the collection of the author.

Female

Body (Fig. 20a) with broad cephalosome. Length $0.92 \mathrm{~mm}(0.70-0.97 \mathrm{~mm})$ and greatest width $0.51 \mathrm{~mm}(0.46-0.55 \mathrm{~mm})$, based on 10 specimens. Greatest dorsoventral thickness 0.33 mm. Somite bearing first pair of legs fused with cephalosome. Epimera of metasomal somites rounded. Ratio of length to width of prosome $1.22: 1$. Ratio of length of prosome to that of urosome $1.94: 1$.

Somite bearing leg 5 (Fig. 20b) $70 \times 170 \mu \mathrm{m}$. Genital double-somite $140 \times 143 \mu \mathrm{m}$, approximately as long as wide, broadest in anterior third, tapering posteriorly (Fig. 20c). Genital areas located dorsolaterally near widest part of somite. Each genital area with 2 very small setae and small rounded process (Fig. 20d). Usual row of long setules on both sides near midregion of somite. Two postgenital somites from anterior to posterior $68 \times 75 \mu \mathrm{m}$ and $44 \times$ $73 \mu \mathrm{m}$ (latter $63 \mu \mathrm{m}$ long medially).

Caudal ramus (Fig. 20e) short, $26 \mu \mathrm{m}$ along outer margin, $18 \mu \mathrm{m}$ along inner margin, and $34 \mu \mathrm{m}$ wide. Outer lateral seta, located dorsally, $130 \mu \mathrm{m}$, dorsal seta $90 \mu \mathrm{m}$, outermost terminal seta $120 \mu \mathrm{m}$, innermost terminal seta $210 \mu \mathrm{m}$, and 2 long median terminal setae 230 $\mu \mathrm{m}$ (outer) and $285 \mu \mathrm{m}$ (inner), all with lateral setules.

Dorsal surface of prosome smooth. Urosome with many small surficial scalelike spines. Ventral surface of somite bearing leg 5 with few small transverse refractile bars (Fig. 20c).

Egg sac not seen.

Rostral area (Fig. 21a) weak. Antennule (Fig. 21b) $400 \mu \mathrm{m}$ long, 19-segmented. Lengths of segments : 17 (47 $\mu \mathrm{m}$ along anterior margin), 13, 13, 13, 13, 13, 13, 13, 12, 16, 26, 26, 26, 26, $26,29,34,10$, and $21 \mu \mathrm{m}$, respectively. Armature: 2, 2, 2, 2, 2, 2, 2, 2, 6, $1+1$ small spine, 2 , 2, 2, 2, 2, 2, 2+1 aesthetasc, 3, and 7. Several setae on first few segments with lateral setules. Antenna (Fig. 21c) $265 \mu \mathrm{m}$ long. Exopod minute, $7 \times 3.5 \mu \mathrm{m}$. Endopod 3-segmented, first segment elongate with few outer distal setules, second segment small, triangular, with 1 seta, 


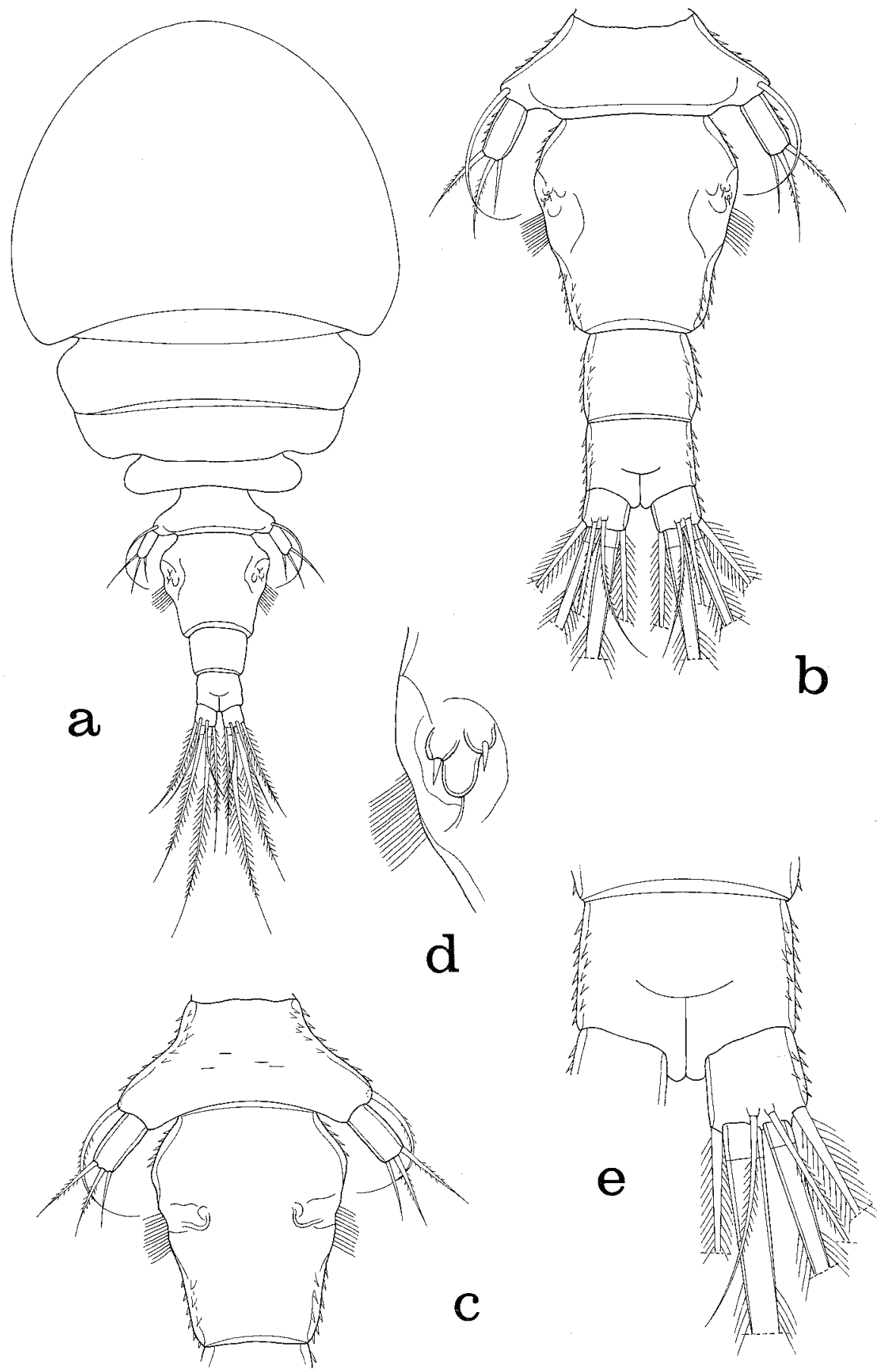

Fig. 20. Hetairosyna wedensis, new species, female. a, body, dorsal (scale A) ; b, urosome, dorsal (G) ; c, somite bearing fifth pair of legs and genital double-somite, ventral (G) ; d, genital area, dorsal (D) ; e, anal somite and caudal ramus, dorsal (C). 


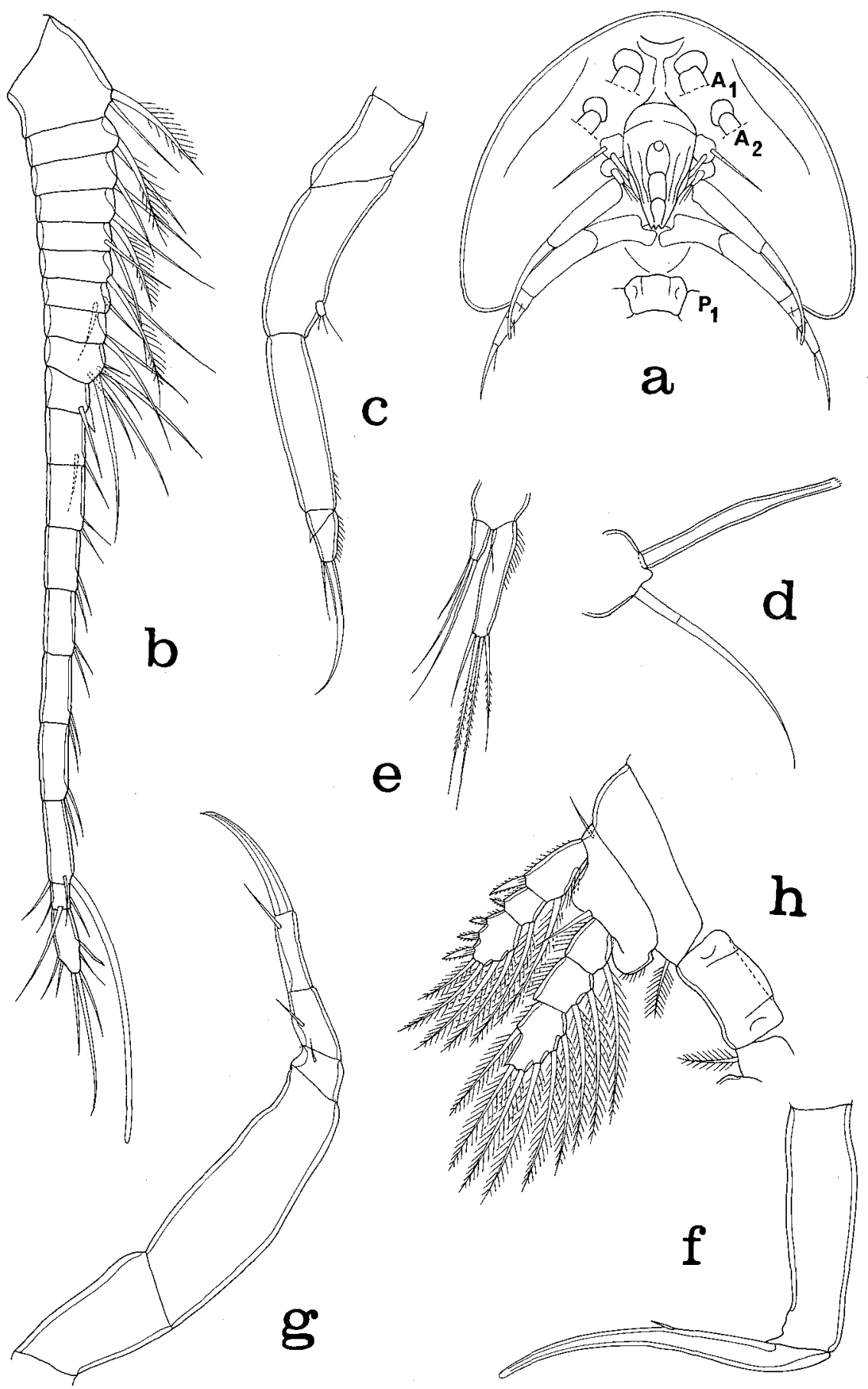

Fig. 21. Hetairosyna wedensis, new species, female. a, cephalosome, ventral (scale A) ; b, antennule, antero-outer $(B)$; c, antenna, posterior $(B) ; d$, mandible, posterior $(G)$; e, maxillule, posterior $(B)$; maxilla, inner $(B)$; g, maxilliped, posterior $(B)$; $h$, leg 1 and intercoxal plate, anterior $(G), A_{1}=$ antennule, $\mathrm{A}_{2}=$ antenna, $\mathrm{P}_{1}=\operatorname{leg} 1$. 


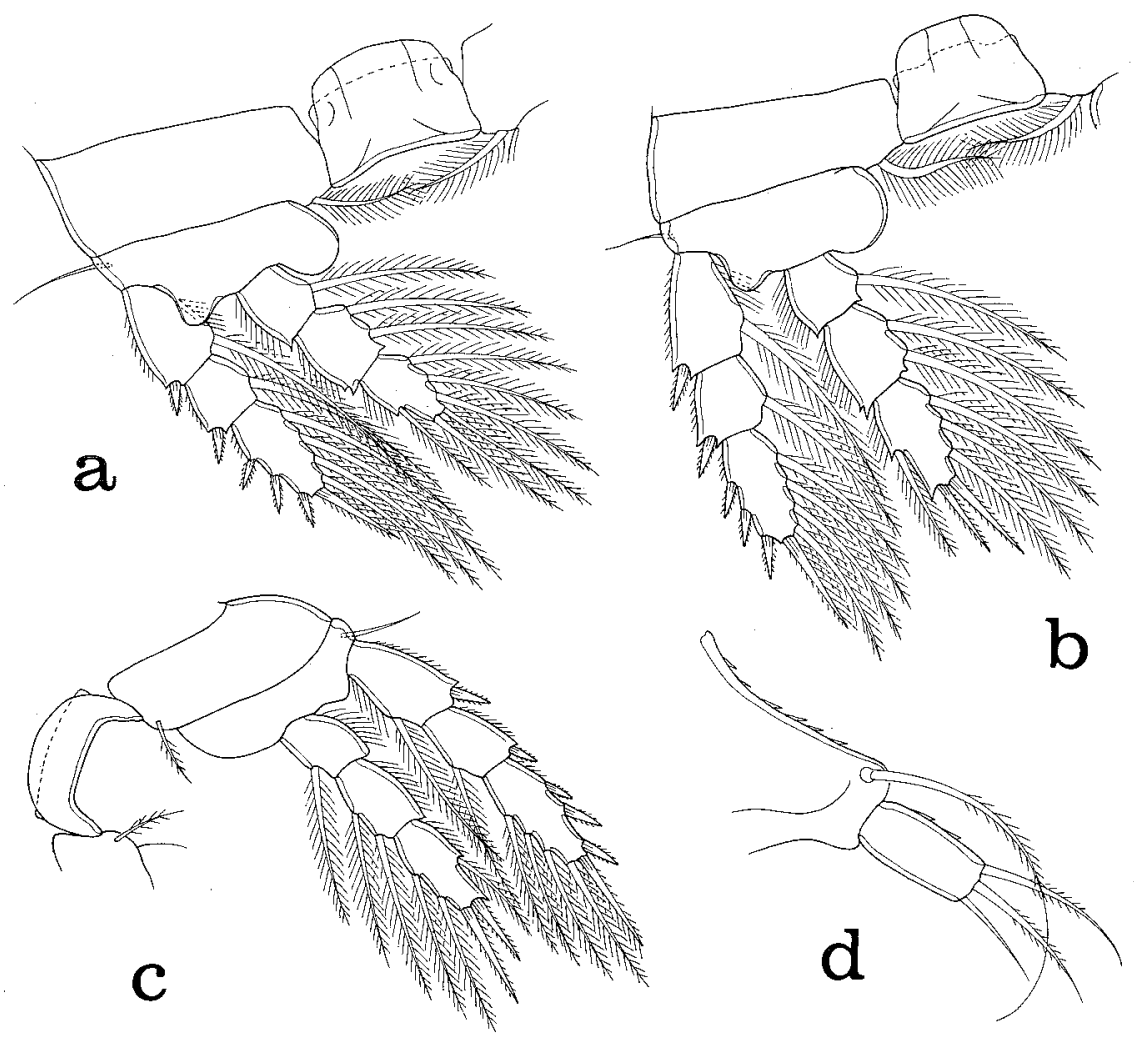

Fig. 22. Hetairosyna wedensis, new species, female. a, leg 2 and intercoxal plate, anterior (scale G); b, leg 3 and intercoxal plate, anterior $(G)$; c, leg 4 and intercoxal plate, anterior (G); e, leg 5, dorsal (B).

and third segment short, armed terminally with claw $57 \mu \mathrm{m}$ and 1 seta and having outer setules.

Siphon (Fig. 21a) $130 \mu \mathrm{m}$ long, reaching to level of maxillipeds. Mandible (Fig. 21d) with slender blade $125 \mu \mathrm{m}$ with finely serrated tip, palp 1-segmented, $135 \mu \mathrm{m}$ long including seta. Maxillule (Fig. 21e), maxilla (Fig. 21f), and maxilliped (FIg. 21g) resembling those of congeners. Claw of maxilliped $60 \mu \mathrm{m}$.

Ventral area between maxillipeds and first pair of legs as in Fig. 21a.

Legs 1-4 (Figs. 21h, 22a-c) as in congeners, with spine and setal formula as in H. galaxeae above, except third segment of endopod of leg 2 with 1,2,3 instead of 1,II,3 as in that species. Inner spine on basis of leg 1 (Fig. 21h) $27 \mu \mathrm{m}$. Leg 4 with inner seta on coxa (Fig. 22c) $33 \mu \mathrm{m}$ with weak setules; 2 terminal spines on endopod $52 \mu \mathrm{m}$ and $33 \mu \mathrm{m}$.

Leg 5 (Fig. 22d) with free segment $44 \times 21 \mu \mathrm{m}$, ratio $2.1: 1$. Three terminal setae from outer to inner 60,51 , and $31 \mu \mathrm{m}$, outer 2 setae with few short setules. Dorsal seta on body somite near insertion of free segment long, $90 \mu \mathrm{m}$, and whiplike. In few specimens, free segment with 2 or 3 small outer scalelike setae, in others this segment smooth.

Leg 6 represented by 2 small setae on genital area (Fig. 20d).

Color of living specimens in transmitted light opaque gray, eye red. 
Male. Unknown.

Etymology

The name is formed from Weda, the bay on the eastern coast of Halmahera where the copepods were found, and the Latin suffix -ensis, denoting place.

Remarks

The new species may be distinguished from its four congeners by a combination of the following characters: (1) several setae on the proximal segments of the antennule having lateral setules, (2) dorsal seta of leg 5 long $90 \mu \mathrm{m}$ and whiplike, and (3) palp of the mandible longer than the blade.

Key to females of the genus Hetairosyna

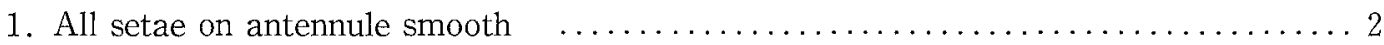

- Several proximal setae on antennule with lateral setules ....H. wedensis, new species

2. Genital double-somite longer than wide $\ldots \ldots \ldots \ldots \ldots \ldots . . \ldots$ terpnae Humes, 1991

Genital double-somite subquadrate or slightly wider than long $\ldots \ldots \ldots \ldots \ldots \ldots . .3$

3 . Convex margin of first segment of antennule with small spinules; third segment of exopod of leg 1 with II,I,4 $\ldots \ldots \ldots \ldots \ldots \ldots \ldots \ldots \ldots \ldots \ldots \ldots . . . \ldots \ldots$. sororia Humes, 1991

- Convex margin of first segment of antennule smooth; third segment of exopod of leg 1

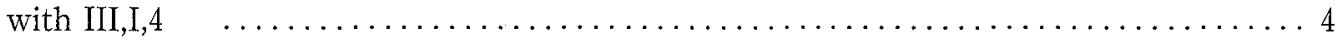

4. Prosome broad, orbicular; epimera of prosomal somites having serrated fringe ........................................... laciniata Humes, 1991

- Prosome somewhat tapered anteriorly; epimera of prosomal somites smooth

H. galaxeae, new species

\section{Hetairosynopsis, new genus}

Diagnosis. Asterocheridae. Female. Two postgenital somites. Rostrum well defined. Siphon short with lateral expansions. Antennule 18-segmented with aesthetasc on segment 16 . Antenna with minute 1-segmented exopod. Mandible with 1-segmented palp bearing long seta. Legs 1-4 with third segment of endopod having 1,$5 ; 1,2,3$; I,II,3 ; and 1,II,2, respectively. Leg 5 with free segment bearing 3 setae.

Male. Resembling female but with 3 postgenital somites and 15-segmented geniculate antennule.

Associated with Scleractinia.

Gender masculine.

Type species. Hetairosynopsis bucculentus, new species.

Etymology

The name is a combination of Hetairosyna and the suffix -opsis, Greek meaning appearance.

Remarks

The new genus is close to Hetairosyna Humes, 1991b, but differs principally in having an elongate well-defined rostrum, an 18-segmented antennule in the female and 15-segmented antennule in the male, the siphon provided with a pair of large lobelike lateral expansions, and the two terminal elements on the third segment of the endopod of leg 2 being slightly spiniform setae. 


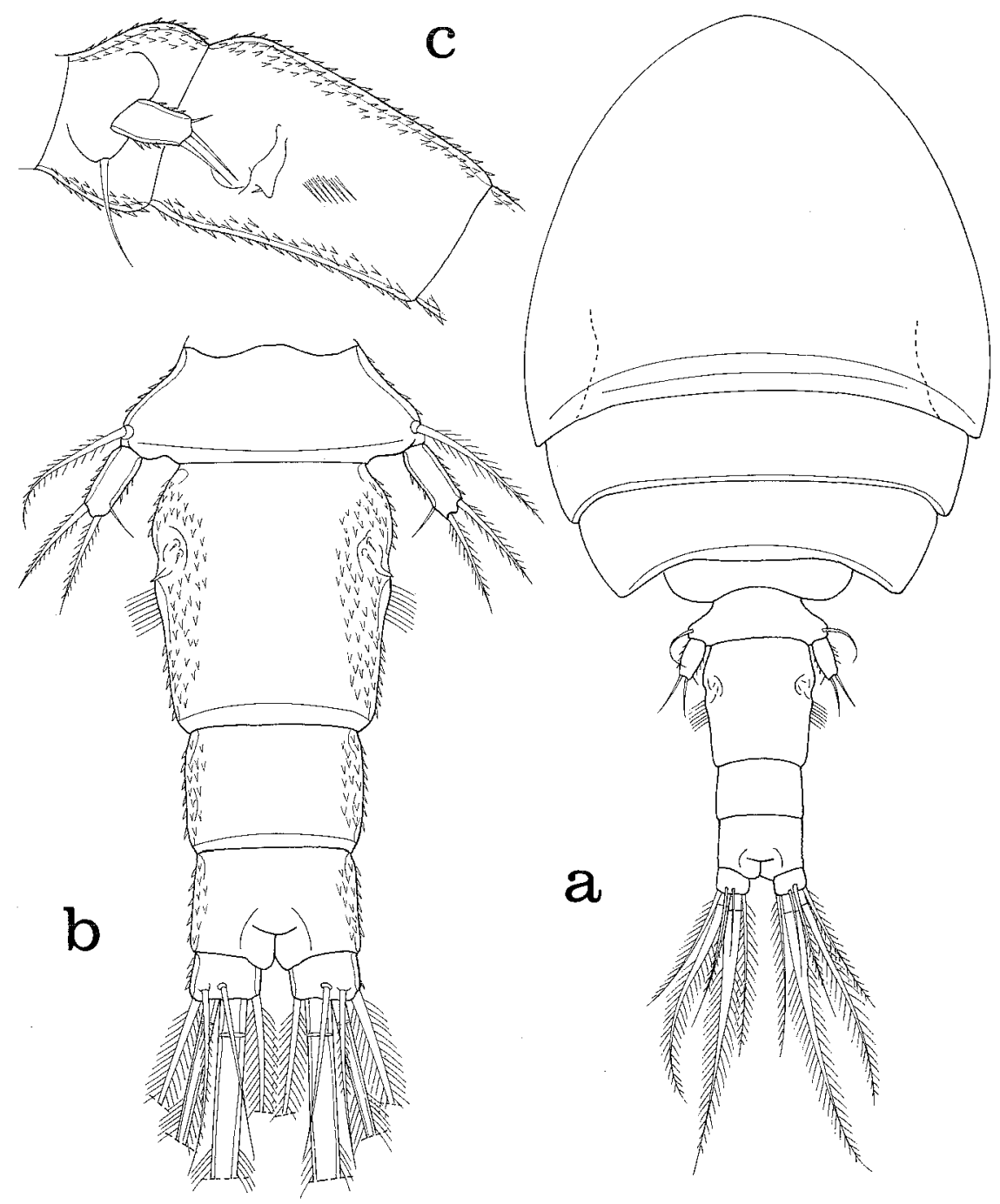

Fig. 23. Hetairosynopsis bucculentus, new genus, new species, female. a, body, dorsal (scale A); b, urosome, dorsal $(G)$; c, somite bearing fifth pair of legs and genital double-somite, lateral $(G)$.

Type material. 94 후우, 11 송 from Galaxea clavus (Dana), in $1 \mathrm{~m}$, Pte. de Tafondro, Nosy Bé, northwestern Madagascar, 19 ix 1963. Holotype ㅇ (USNM 268460), allotype 令 (USNM 268461, and 87 paratypes (80 우우, 7 송ㅅㅇ) (USNM 268462) deposited in the National Museum of Natural History, Smithsonian Institution, Washington, D.C. Remaining paratypes, 3 우 우, 3 숑숑, dissected, in the collection of the author.

Additional material. 21 우우 from Galaxea clavus, in $1 \mathrm{~m}$, Nosy N’Tangam, Nosy Bé, Madagascar, 5 ix $1963 ; 19$ 우우, 1 令 from Galaxea sp., in $6 \mathrm{~m}$, Nosy N'Tangam, Nosy Bé, 24 vi 1964; 5 우우 from Galaxea fascicularis (L.), in $2 \mathrm{~m}$, west of Pte. Mahatsinjo, Nosy Bé, Madagascar. 31 i 1964.

Female 
Body (Fig. 23a) with moderately broad prosome. Length $1.03 \mathrm{~mm}(1.00-1.05 \mathrm{~mm})$ and greatest width $0.58 \mathrm{~mm}(0.55-0.61 \mathrm{~mm})$, based on 10 specimens. Greatest dorsoventral thickness $0.36 \mathrm{~mm}$. Somite bearing first pair of legs fused with cephalosome, but showing on both sides internal anteriorly directed sclerotization. Metasomal somites with only slightly pointed or rounded epimera. Tergum of somite bearing leg 4 much narrower than that of preceding somite. Ratio of length to width of prosome $1.25: 1$. Ratio of length of prosome to that of urosome $1.88: 1$.

Somite bearing leg 5 (Fig. 23b) $60 \times 177 \mu \mathrm{m}$. Genital double-somite about as long as wide, $150 \times 146 \mu \mathrm{m}, 117 \mu \mathrm{m}$ wide in posterior third. In dorsal view showing 2 small lateral expansions, anterior one slightly larger than posterior one. Between these 2, at level of posterior expansion, row of 7 or 8 long setules. Genital areas (Figs. 23b,c) located near anterior expansion, bearing 2 minute setae. Two postgenital somites from anterior to posterior $68 \times$ $99 \mu \mathrm{m}$ and $60 \times 91 \mu \mathrm{m}$.

Caudal ramus (Fig. 24a) wider than long, $25 \times 40 \mu \mathrm{m}$, ratio $0.63: 1$. Outer lateral seta, placed dorsally on slight pedicel, $160 \mu \mathrm{m}$ long with few short setules. Dorsal seta $70 \mu \mathrm{m}$ and smooth. Outermost terminal seta $240 \mu \mathrm{m}$, innermost terminal seta $270 \mu \mathrm{m}$, and 2 median terminal setae $300 \mu \mathrm{m}$ (outer) and $360 \mu \mathrm{m}$ (inner) and proximally swollen, all with long lateral setules.

Surface of prosome smooth without visible sensilla, but urosome, including caudal rami, with small surficial scalelike spines (Fig. 23b,c) (those on dorsal and ventral surfaces not shown in figures).

Egg sac (Fig. 24b) $396 \times 230 \mu \mathrm{m}$, containing several eggs $101-146 \mu \mathrm{m}$ in diameter.

Rostrum (Fig. 24c) elongate, well defined, with slender neck and posteroventral bulb. Antennule (Fig. 24d) 18-segmented, $370 \mu \mathrm{m}$ long. Lengths of its segments : 18 (49 $\mu \mathrm{m}$ along anterior margin), 13, 10,10,10,10,10,10,13,14,27, 27, 27, 27, 31, 39, 15, and $21 \mu \mathrm{m}$, respectively. Formula for armature: 1, 2, 2, 2, 2, 2, 2, 2, 6, 1, 2, 2, 2, 2, 2, 2+1 aesthetasc, 2, and 6. All setae smooth. Antenna (Fig. 24e) $255 \mu \mathrm{m}$ long, slender. Coxa unarmed. Basis with minute exopod bearing seta. Endopod 2-segmented, elongate, first segment $91 \mu \mathrm{m}$ long and unarmed, second segment short, $18 \mu \mathrm{m}$, bearing 1 small seta laterally and terminally slender clawlike seta $52 \mu \mathrm{m}$ and 2 small setae.

Siphon (Figs. 24f,g, 25d) short, length approximately $148 \mu \mathrm{m}$, with pair of large rounded lateral expansions on ventral (anterior) surface. Width at expansions $138 \mu \mathrm{m}$.

Mandible (Fig. 24h) with long slender blade $133 \mu \mathrm{m}$, its tip expanded, and obliquely transverse, and very finely dentate. Palp 1-segmented, bearing long slightly setulose seta. Maxillule (Fig. 25a) with small slender outer lobe bearing 3 setae and larger slender inner lobe with 4 setae. Maxilla (Fig. 25b) with long slender basal segment bearing long slightly recurved claw $(155 \mu \mathrm{m})$ having on convex margin short seta and proximal to it row of minute spines. Maxilliped (Fig. 25c) $300 \mu \mathrm{m}$ long, with first segment having minute inner seta. Long second segment unarmed. Third, fourth, and fifth segments each with 1 seta. Fifth segment $49 \mu \mathrm{m}$ long. Terminal claw $70 \mu \mathrm{m}$. Arrangement of mouthparts as shown in Fig. 25d.

Ventral region between maxillipeds and first pair of legs as in Fig. 25d.

Legs 1-4 (Figs. 25e-g, 26a) with 3-segmented rami. Formula for armature:

\begin{tabular}{|c|c|c|c|c|c|c|c|c|}
\hline $\mathrm{P}_{1}$ & coxa & $0-1$ & basis & $1-I$ & $\exp$ & I-1; & $\mathrm{I}-1$; & III, 4 \\
\hline & & & & & enp & $0-1$; & $0-2$; & 1,5 \\
\hline$P_{1}$ & coxa & $0-1$ & basis & $1-0$ & $\exp$ & $\mathrm{I}-1$; & I-1; & III,I,4 \\
\hline & & & & & enp & $0-1$; & $0-2$; & $1,2,3$ \\
\hline $\mathrm{P}_{3}$ & coxa & $0-1$ & basis & $1-0$ & $\exp$ & $\mathrm{I}-1$ & I-1 & III,I, 4 \\
\hline & & & & & enp & $0-1$ & $0-2$ & $1, \mathrm{II}, 3$ \\
\hline & coxa & $0-1$ & basis & $1-0$ & $\exp$ & I-1; & $\mathrm{I}-1$; & III,I,4 \\
\hline & & & & & enp & $0-1 ;$ & $0-2$; & 1,II,2 \\
\hline
\end{tabular}



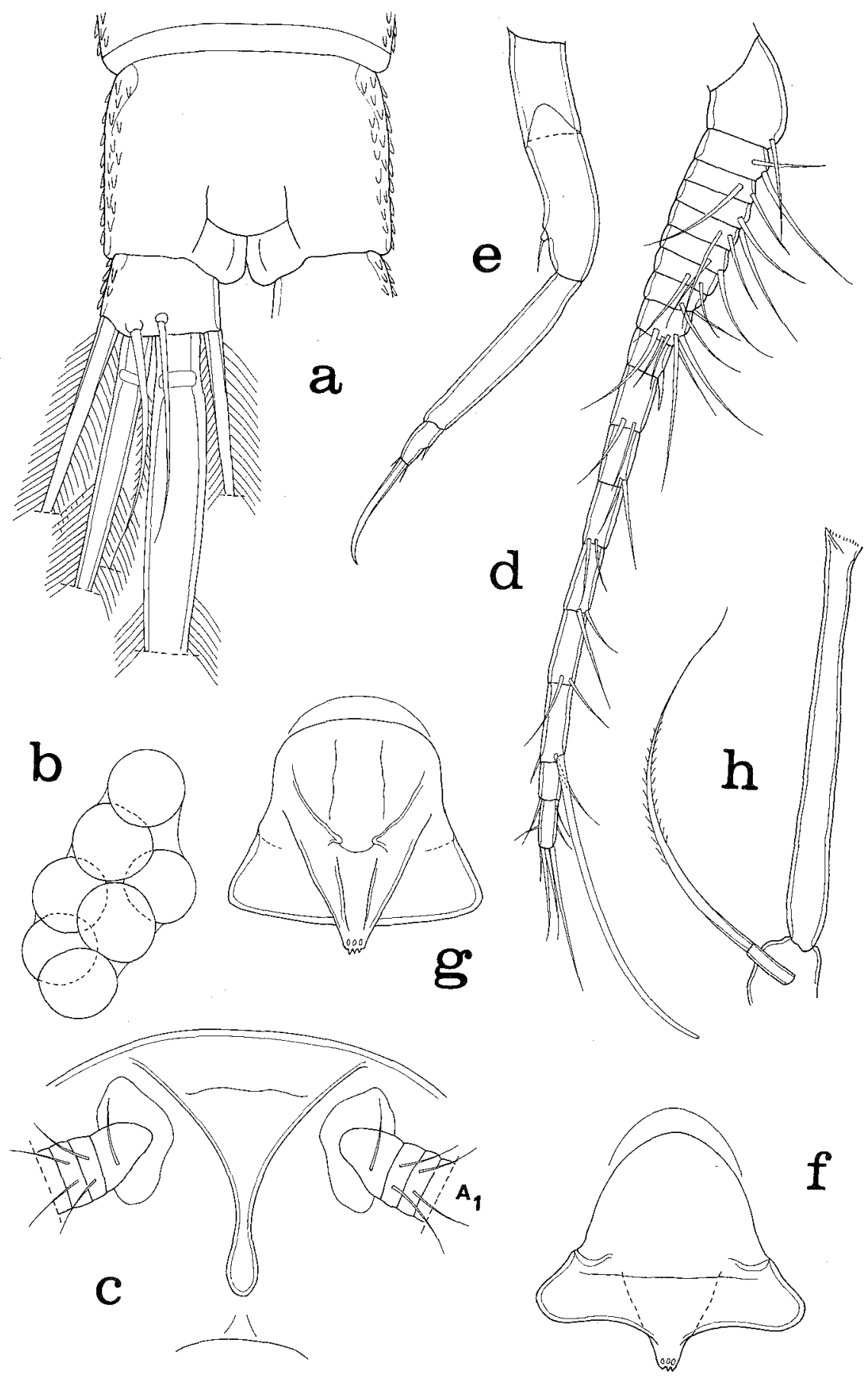

Fig. 24. Hetairosynopsis bucculentus, new genus, new species, female. a, anal somite and caudal ramus, dorsal (scale C) ; b, egg sac, ventral (A) ; c, rostrum, ventral (B) ; d, antennule, anterodorsal (B) ; e, antenna, anterior (B) ; f, siphon, ventral $(G)$; $g$, siphon, dorsal $(G)$; h, mandible, anterior $(C)$. $\mathrm{A}_{1}=$ antennule. 


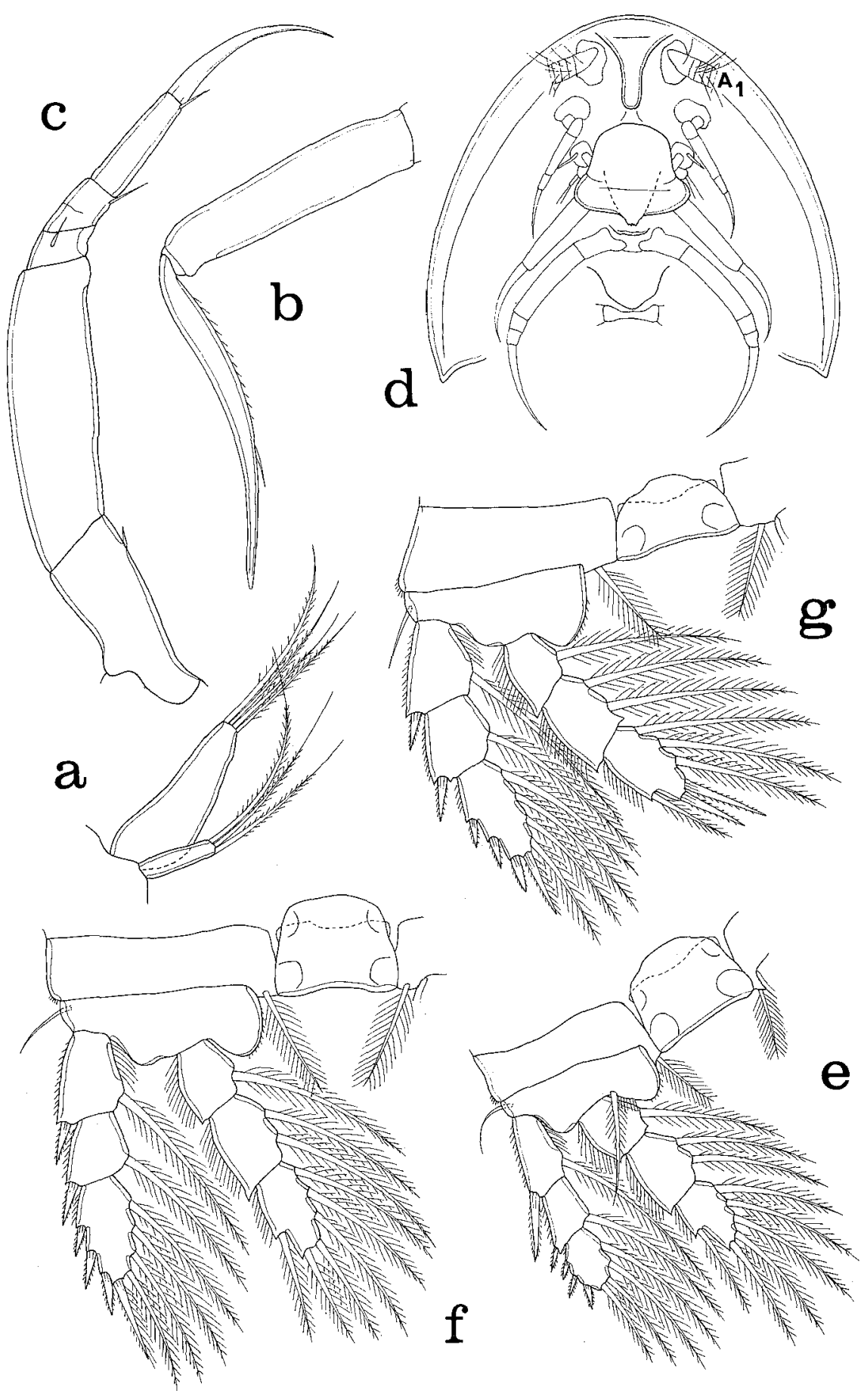

Fig. 25. Hetairosynopsis bucculentus, new genus, new species, female. a, maxillule, anterior (scale C) ; b, maxilla, anterior (B) ; c, maxilliped, postero-inner (B) ; d, cephalosome, ventral (A); e, leg 1 and intercoxal plate, anterior $(\mathrm{G})$; f, leg 2 and intercoxal plate, anterior $(\mathrm{G})$; g, leg 3 and intercoxal plate, anterior $(G) . A_{1}=$ antennule. 


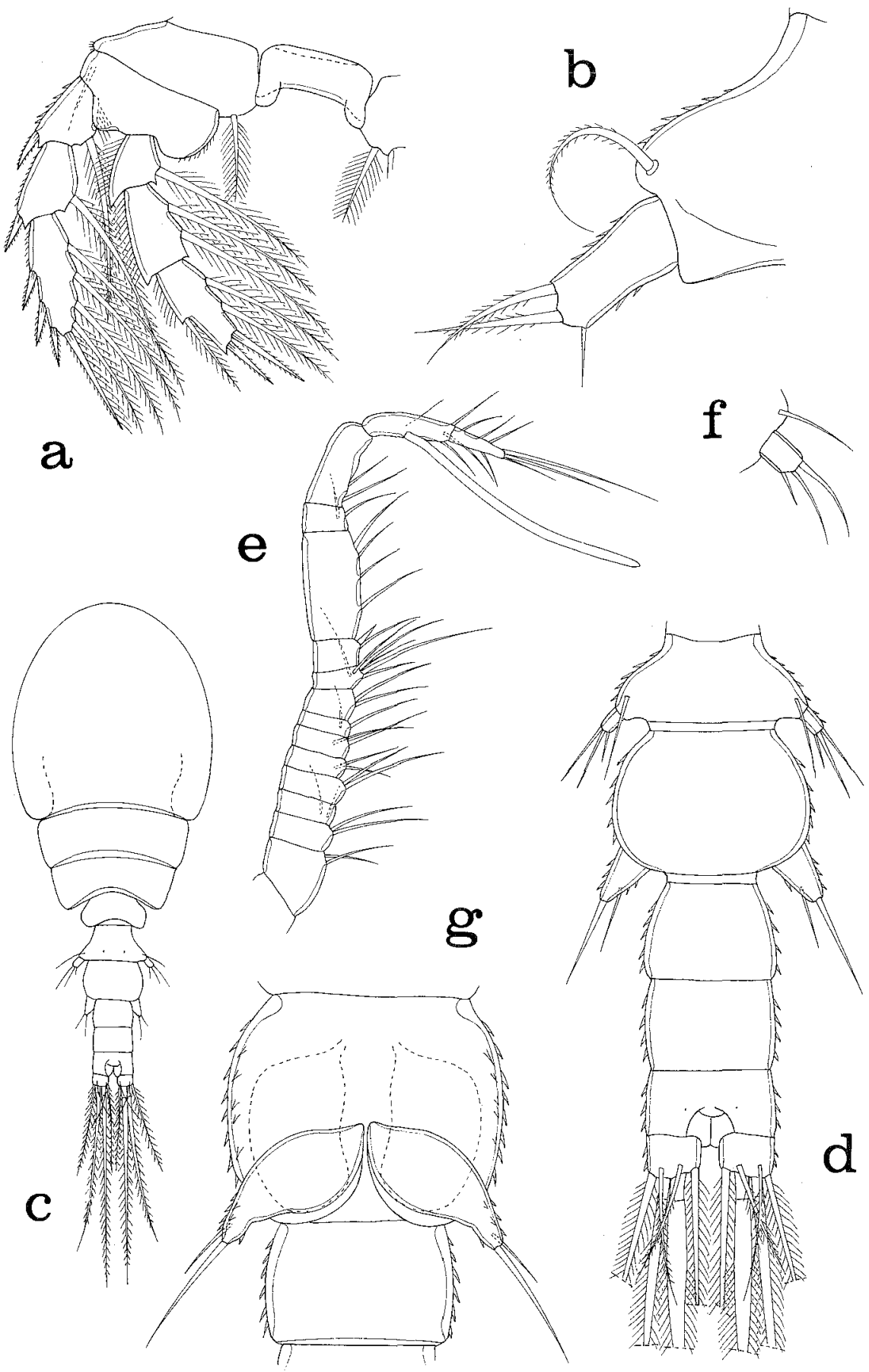

Fig. 26. Hetairosynopsis bucculentus, new genus, new species. Female. a, leg 4 and intercoxal plate, anterior (scale G); b, leg 5, dorsal (C). Male. c, body, dorsal (A); d, urosome, dorsal (B); e, antennule, posteroventral (B) ; f, leg 5, dorsal (C) ; g, genital somite, showing sixth pair of legs, and first postgenital somite, ventral (C). 
In all legs outer corner of coxa with small spinules, expanded inner margin of basis with minute spines, and outer margins of exopodal segments with row of small spines. Basis of leg 1 with inner spine long, $50 \mu \mathrm{m}$, and setiform. Leg 1 with outer spine on first segment of exopod large, $39 \mu \mathrm{m}$ long, 3 times longer than spine on second segment, $13 \mu \mathrm{m}$. Two terminal setae on third segment of endopod of leg 2 slightly spiniform.

Leg 5 (Figs. 23b,c, 26b) with free segment $47 \times 25 \mu \mathrm{m}$, ratio $1.88: 1$, bearing terminally 2 lightly plumose setae approximately $50 \mu \mathrm{m}$ long and slightly subterminally smaller smooth seta $18 \mu \mathrm{m}$. Dorsal seta on body near insertion of free segment approximately $66 \mu \mathrm{m}$, with short lateral setules, in most specimens strongly flexed. Outer and inner edges of free segment with few small scalelike spines.

Leg 6 probably represented by 2 minute setae on genital area (Fig. 23b).

Color of living specimens opaque gray, eye red.

Male

Prosome (Fig. 26c) not as broad as in female. Length $0.66 \mathrm{~mm}(0.65-0.68 \mathrm{~mm})$ and greatest width $0.30 \mathrm{~mm}(0.29-0.30 \mathrm{~mm})$, based on 10 specimens. Greatest dorsoventral thickness $0.21 \mathrm{~mm}$. Ratio of length to width of prosome $1.62: 1$. Ratio of length of prosome to that of urosome $2.01: 1$.

Somite bearing leg 5 (Fig. 26d) $36 \times 96 \mu \mathrm{m}$. Genital somite $65 \times 90 \mu \mathrm{m}$, wider than long, ratio $0.72: 1$. Length $78 \mu \mathrm{m}$ including leg 6 . Three postgenital somites from anterior to posterior $36 \times 65,36 \times 60$, and $30 \times 56 \mu \mathrm{m}$.

Caudal ramus (Fig. 26d) similar to that of female but smaller, $16 \times 23.5 \mu \mathrm{m}$, ratio $0.68: 1$.

Body surface without sensilla. Urosome bearing surficial scalelike spines as in female.

Rostral area as in female. Antennule (Fig. 26e) geniculate, 15-segmented, with long aesthetasc on penultimate segment. Lengths of segments (measured along their posterior nonsetiferous margins) : 18 (30 $\mu \mathrm{m}$ along anterior margin), 13, 10, 10, 10, 10, 8, 10, 8, 14, 65, 13, 40,34 , and $26 \mu \mathrm{m}$, respectively. Armature: $2,2,2,2,2,2,2,2,6,2,4,2,2,4+1$ aesthetasc, and 7. All setae smooth. Antenna as in female.

Siphon, mandible, maxillule, maxilla, maxilliped, postoral area, and legs 1-4 as in female.

Leg 5 (Fig. 26f) with small free segment $13 \times 10 \mu \mathrm{m}$, ratio $1.3: 1$, and armed as in female.

Leg 6 (Fig. 26g) prominent posteroventral flap on genital somite bearing 2 setae $22 \mu \mathrm{m}$ and $44 \mu \mathrm{m}$.

Spermatophore seen only inside body of male (Fig. 26g).

Color as in female.

Etymology

The name is from Latin, bucculentus, meaning with full cheeks, referring to the lobelike expansions on the siphon.

\section{Madacheres, new genus}

Diagnosis. Asterocheridae. Female. Somite bearing leg 1 fused with cephalosome. Urosome with 2 postgenital somites. Rostrum linguiform. Antennule 19-segmented with aesthetasc on segment 17. Antenna with coxa, basis, 1-segmented exopod, and 3-segmented endopod. Siphon elongated pyriform, reaching nearly to level of first pair of legs. Mandible with 2segmented palp. Maxillule with base swollen on outer side. Maxilla and maxilliped resembling those of other asterocherids. Legs 1-4 with 3-segmented rami. Armature of third segment of endopod of leg $3,1,1, \mathrm{I}, 3$, and for that of leg 4, 1,1,I,2. Leg 5 with free segment bearing 3 setae.

Male. Unknown.

Gender masculine. 
Type species. Madacheres serrulatus, new species.

\section{Etymology}

The generic name is formed from Mada-, part of Madagascar and referring to the area where the type specimens were found, and the combining form -cheres, frequently used in the names of asterocherid genera.

\section{Remarks}

Madacheres differs from all except two asterocherid genera in having a 2-segmented palp on the mandible; in the others the palp is 1-segmented. In both Monocheres Stock, 1966, and Psilomyzon Stock, 1965, the palp is 2-segmented. However, in Monocheres leg 5 has no free segment and is reduced to a row of spinules and a single seta. In Psilomyzon, the armature of the 3-segmented rami of legs 1-4 is much reduced, with the endopod of leg 4 being completely unarmed.

\section{Madacheres serrulatus, new species}

(Figs. 27-29)

Type material. 2 우우 from Galaxea fascicularis (L.), in $2 \mathrm{~m}$, west of Pte. Mahatsinjo, Nosy Bê, northwestern Madagascar, 31 i 1964. Holotype (USNM 268463) deposited in the National Museum of Natural History, Smithsonian Institution, Washington, D.C. Paratype, dissected, in the collection of the author.

Female

Body (Fig. 27a) with broad flattened prosome. Length $1.20 \mathrm{~mm}(1.16-1.24 \mathrm{~mm})$ and greatest width $0.85 \mathrm{~mm}(0.83-0.88 \mathrm{~mm})$, based on 2 specimens. Cephalosome broader than following metasomal somites. Somites bearing legs 1-3 with rounded epimera, somite bearing leg 4 partially overlapped dorsally by tergum of preceding somite and having pointed epimera. Ratio of length to width of prosome $0.98: 1$. Ratio of length of prosome to that of urosome $2.15: 1$.

Somite bearing leg 5 (Fig. 27b,c) $73 \times 203 \mu \mathrm{m}$. Genital double-somite in dorsal view $198 \times$ $190 \mu \mathrm{m}$, ratio $1.04: 1$, approximately as long as wide, with 3 small lateral expansions. Genital areas located dorsolaterally just posterior to midregion of somite. Each area with 2 small unequal setae. Row of several long setules on both sides of somite at level of posterior expansion. Two postgenital somites from anterior to posterior $104 \times 102$ and $68 \times 99 \mu \mathrm{m}$, with surficial scales. Genital and first postgenital somites with posteroventral fringe of hyaline spines (Fig. 27c).

Caudal ramus (Figs. 27d, 28a) short, $47 \mu \mathrm{m}$ along outer side, $34 \mu \mathrm{m}$ along inner side, and $42 \mu \mathrm{m}$ in greatest width. Ratio of greatest length to average width $(40 \mu \mathrm{m}) 1.18: 1$. Outer lateral seta (displaced dorsally) $260 \mu \mathrm{m}$, outermost terminal seta $250 \mu \mathrm{m}$, innermost terminal seta $308 \mu \mathrm{m}$, and 2 median terminal setae $560 \mu \mathrm{m}$ (outer) and $690 \mu \mathrm{m}$ (inner), all with lateral setules. Dorsal seta $140 \mu \mathrm{m}$ and smooth. Outer side of ramus with few small scales. Posteroventral margin of ramus with large triangular process (Fig. 28a).

Body surface with few sensilla (Figs. 27a-c, 28b).

Egg sac not seen.

Rostrum (Fig. 28b) linguiform. Antennule (Fig. 28c) $520 \mu \mathrm{m}$ long, 19-segmented. Lengths of segments : 26 (65 $\mu \mathrm{m}$ along anterior margin), 14, 14, 14, 14, 14, 14, 21, 18, 20, 29, 30, 44, 44, $49,47,48,24$, and $26 \mu \mathrm{m}$, respectively. Armature : 2, 2, 2, 2, 2, 2, 2, 2, 6, $1+1$ spine, 2, 2, 2, 2, 2, 2, 2+1 aesthetasc, 3, and 7. Segments $1,3,4,6$, and 8 with one of setae having blunt bifurcate tip. All setae smooth. Antenna (Fig. 28d) 5-segmented, $286 \mu \mathrm{m}$ long including terminal seta. Coxa and basis unarmed. Exopod minute, $13 \times 8 \mu \mathrm{m}$. First segment of endopod with outer spinules. Second segment with 3 distal outer setae. Third segment with 


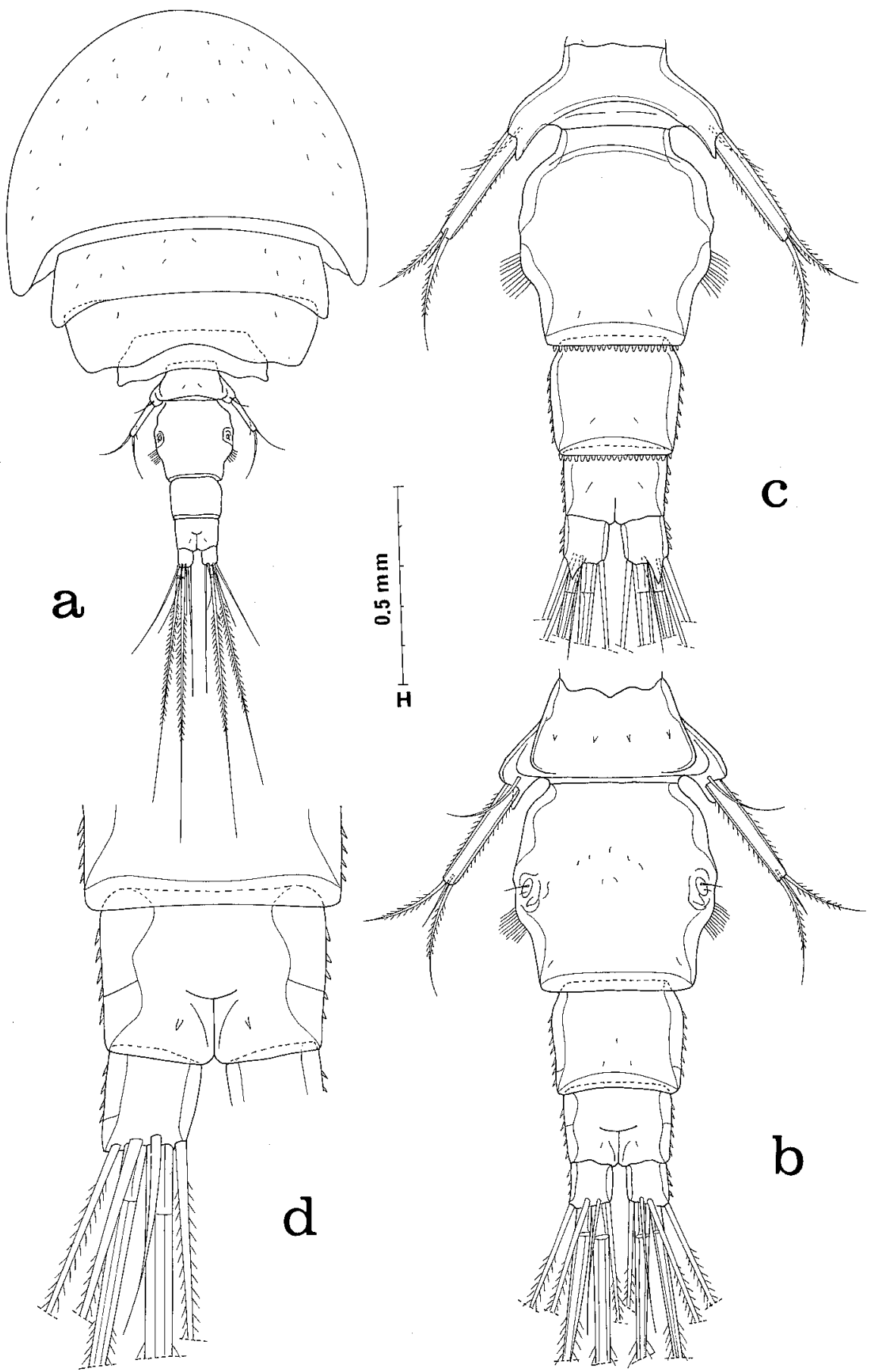

Fig. 27. Madacheres sermulatus, new genus, new species, female. a, body, dorsal (scale H); b, urosome, dorsal $(\mathrm{F})$; c, urosome, ventral $(\mathrm{F})$; d, anal somite and caudal ramus, dorsal (B). 

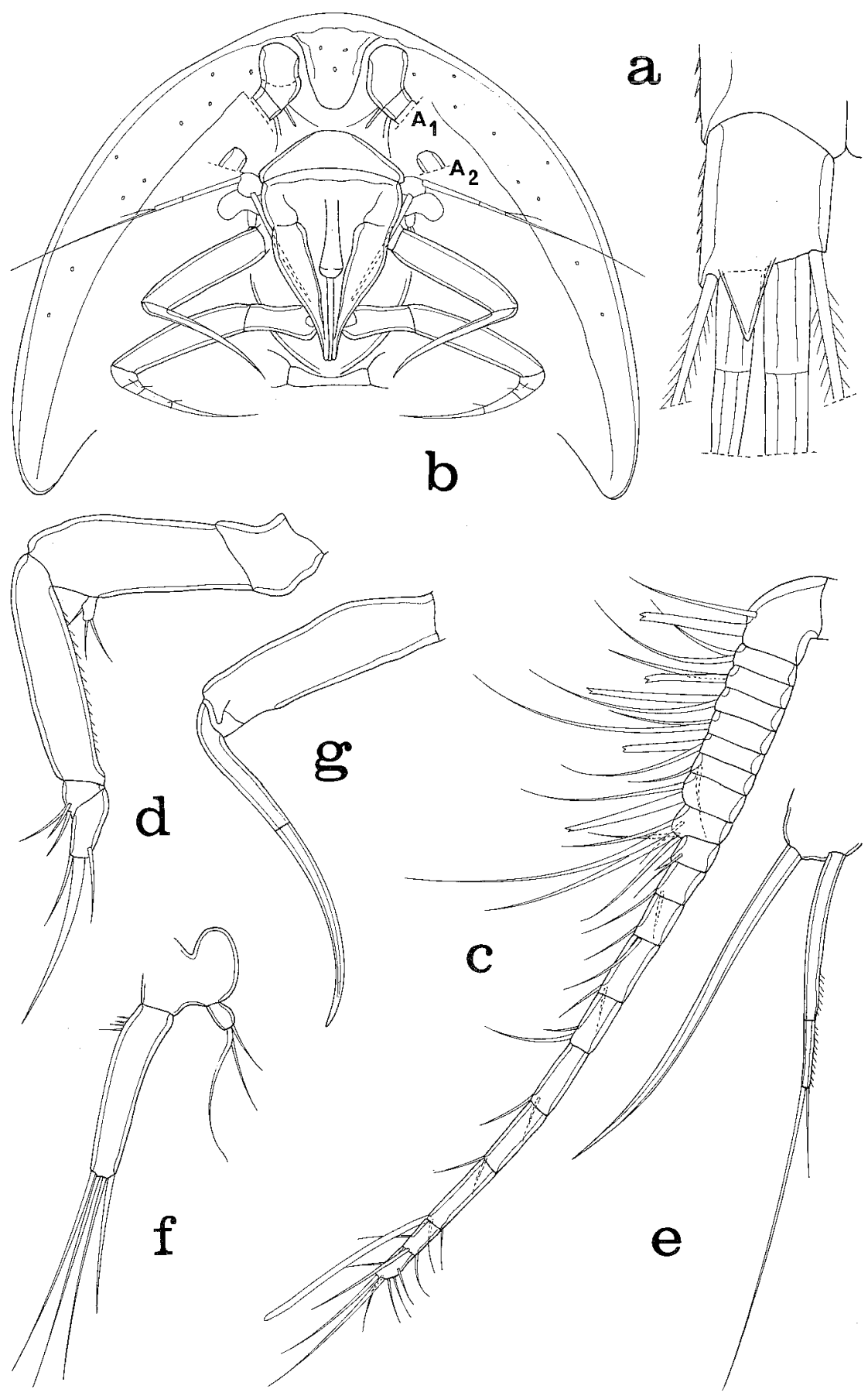

Fig. 28. Madacheres sermulatus, new genus, new species, female. a, caudal ramus, ventral (scale $\mathrm{C}$ ); b, cephalosome, ventral (A); c, antennule, antero-outer $(G)$; d antenna, posterior (B); e, mandible, ventral $(G)$; f, maxillule, posterior $(G) ; g$, maxilla, posteroventral $(G)$. $A_{1}=$ antennule, $A_{2}=$ antenna. 


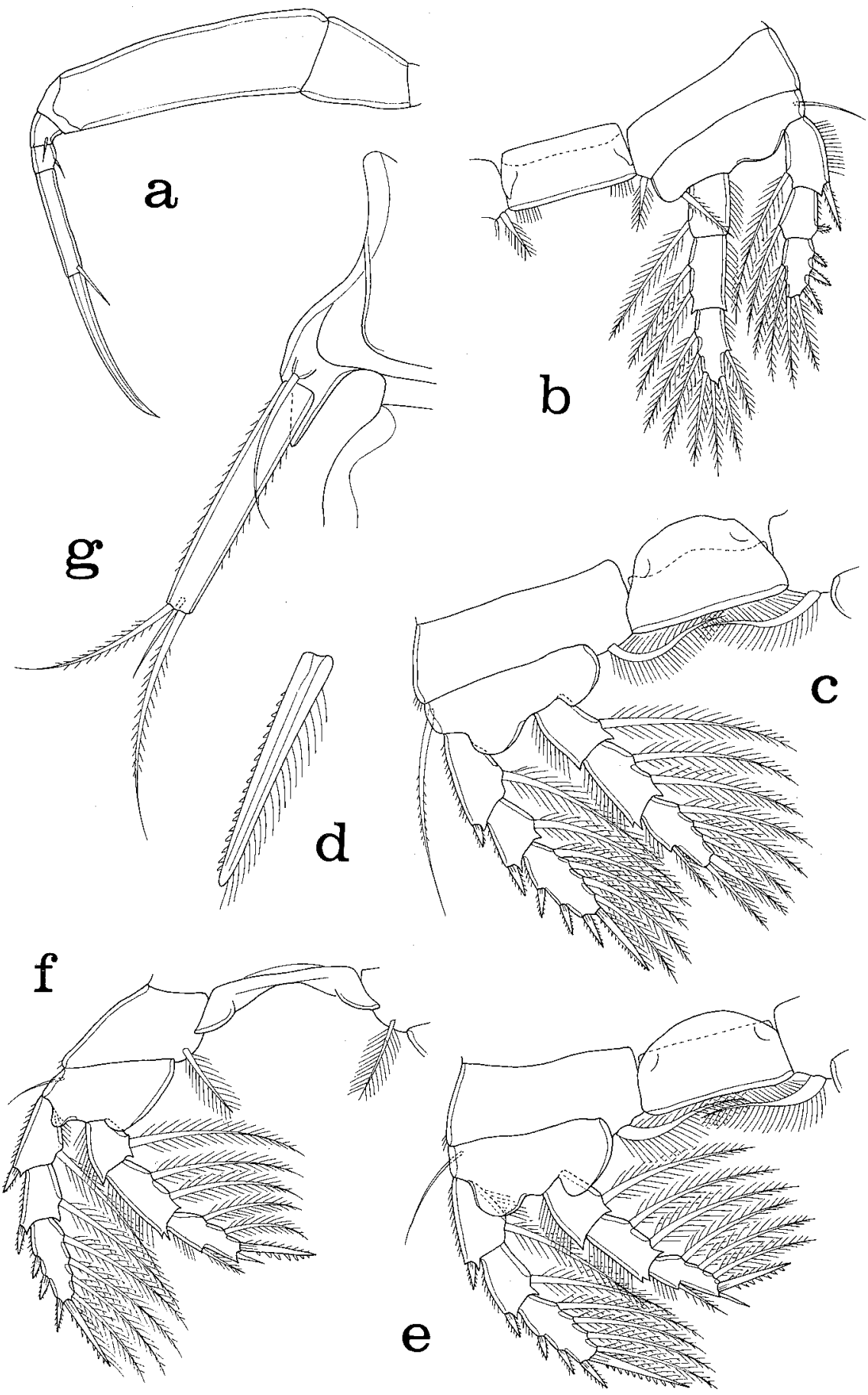

Fig. 29. Madacheres sermilatus, new genus, new species, female. a, maxilliped, posterior (scale G); $b$, leg 1 and intercoxal plate, anterior $(F)$; c, leg 2 and intercoxal plate, anterior $(F)$; d, terminal spine on third segment of exopod of leg 2, anterior (D); e, leg 3 and intercoxal plate, anterior (F) ; $f$, leg 4 and intercoxal plate, anterior $(\mathrm{F}) ; \mathrm{g}$, leg 5 , dorsal (B). 
3 terminal setae, middle seta $83 \mu \mathrm{m}$ long.

Siphon (Fig. 28b) elongated, $300 \mu \mathrm{m}$, pyriform, reaching nearly to level of first pair of legs. Mandible (Fig. 28e) with long slender blade, $220 \mu \mathrm{m}$, lacking terminal teeth; palp very long, $350 \mu \mathrm{m}$, slender, extending beyond margins of cephalosome (Fig. 28b), 2-segmented, first segment $109 \mu \mathrm{m}$, second segment $36 \mu \mathrm{m}$, both with posterior marginal spinules, 2 terminal smooth setae $208 \mu \mathrm{m}$ and $47 \mu \mathrm{m}$. Maxillule (Fig. 28f) with basal part greatly expanded outward as rounded lobe. Outer lobe small with 3 setae, inner lobe elongate with 4 terminal setae and bearing proximally few inner setules. Maxilla (Fig. 28g) 2-segmented, first segment unarmed, second segment (claw) long and slender, $220 \mu \mathrm{m}$, with weak division about midway. Maxilliped (Fig. 29a) 5-segmented, first and second segments unarmed, segments 3 , 4, and 5 with 1 seta, and claw $95 \mu \mathrm{m}$.

Legs 1-4 (Fig. 29b,c,e,f) with 3-segmented ram1. Formula for armature:

\begin{tabular}{|c|c|c|c|c|c|c|c|c|}
\hline $\mathrm{P}_{1}$ & coxa & $0-1$ & basis & $1-\mathrm{I}$ & $\begin{array}{l}\text { exp } \\
\text { enp }\end{array}$ & $\begin{array}{l}\mathrm{I}-1 ; \\
0-1\end{array}$ & $\begin{array}{l}\mathrm{I}-1 ; \\
0-2\end{array}$ & III,4 \\
\hline $\mathrm{P}_{2}$ & coxa & $0-1$ & basis & $1-0$ & $\exp$ & I-1; & I-1; & III,I,4 \\
\hline & & & & & enp & $0-1$; & $0-2$; & $1,2,3$ \\
\hline $\mathrm{P}_{3}$ & coxa & $0-1$ & basis & $1-0$ & $\exp$ & I-1; & I-1; & III,I,4 \\
\hline & & & & & enp & $0-1$; & $0-2$; & $1,1, \mathrm{I}, 3$ \\
\hline $\mathrm{P}_{4}$ & coxa & $0-1$ & basis & $1-0$ & $\exp$ & $\mathrm{I}-1$; & I-1; & III,I,4 \\
\hline
\end{tabular}

Leg 1 (Fig. 29b) with intercoxal plate having 2 groups of setules on posterior margin. Inner coxal seta $28 \mu \mathrm{m}$, slightly swollen proximally. Inner spine on basis $46 \mu \mathrm{m}$. Exopod with first segment bearing long setules on outer margin ; distal outer spine long, $44 \mu \mathrm{m}$; distal

Table 1. Copepoda associated with the coral Galaxea in the Indo-Pacific.

\begin{tabular}{|c|c|c|c|c|}
\hline \multirow{2}{*}{ Species } & \multirow{2}{*}{ Madagascar } & \multirow{2}{*}{ New Caledonia } & \multicolumn{2}{|c|}{ Moluccas } \\
\hline & & & Karang Mie & Banda \\
\hline \multicolumn{5}{|l|}{ Cyclopoida } \\
\hline \multicolumn{5}{|l|}{ Cyclopinidae } \\
\hline Pterinopsyllus slirpipes & + & - & - & - \\
\hline \multicolumn{5}{|l|}{ Poecilostomatoida } \\
\hline \multicolumn{5}{|l|}{ Anchimolgidae } \\
\hline Anchimolgus abbreviatus & - & + & - & - \\
\hline Anchimolgus compressus & - & + & + & - \\
\hline Anchimolgus contractus & - & + & + & + \\
\hline Anchimolgus moluccanus & - & - & + & + \\
\hline Anchimolgus nasutus & - & + & + & - \\
\hline Anchimolgus tenaus & - & + & - & - \\
\hline Clamocus spinifer & - & + & + & - \\
\hline Karanges galaxeanus & - & - & + & + \\
\hline Karanges hypsorophus & - & + & + & - \\
\hline \multicolumn{5}{|l|}{ Xarifiidae } \\
\hline Xarifia exserens & - & - & + & - \\
\hline Xarifia sp. & + & - & - & - \\
\hline \multicolumn{5}{|l|}{ Siphonostomatoida } \\
\hline \multicolumn{5}{|l|}{ Asterocheridae } \\
\hline Hetairosyna galaxeae & - & - & + & - \\
\hline Hetairosyna wedensis & - & - & + & - \\
\hline Hetairosynopsis bucculentus & + & - & - & - \\
\hline Madacheres serrulatus & + & - & - & - \\
\hline
\end{tabular}


outer spine on second segment $10.5 \mu \mathrm{m}$. Leg 2 (Fig. 29c) with outer seta on basis unusually long, $190 \mu \mathrm{m}$. Terminal spine on exopod (Fig. 29d) with outer margin having sawlike spines, inner margin with setules. Inner of 2 terminal setae on third segment of endopod swollen proximally. Legs 3 and 4 with 2 terminal spines on third segment of endopod very unequal (Fig. 29e,f). Outer distal corner of coxa of legs 2-4 with small spinules.

Leg 5 (Fig. 29g) with free segment long and slender, $114 \times 16 \mu \mathrm{m}$, ratio $7.13: 1$. Three terminal setae from outer to inner 86,35 , and $99 \mu \mathrm{m}$, all with short lateral setules. Adjacent dorsal seta about half length of free segment. Both margins of free segment with spinules. Prominent process on body somite near insertion of free segment (Figs. 27c, 29g).

Leg 6 represented by 2 unequal setae on genital area (Fig. 27b).

Color of living specimens in transmitted light slightly opaque gray, eye red.

Male. Unknown.

\section{Etymology}

The name serrulatus, Latin meaning denticulated like a little saw, refers to the serrated spines on legs 2-4.

Remarks

Females of Madacheres serrulatus may be differentiated from other asterocherids by : the broad prosome, the two postgenital somites, the serrated spines on legs $2-4$, the long slender free segment of leg 5 , the triangular posteroventral process on the caudal ramus, the very long 2 -segmented palp on the mandible, the rounded outer expansion on the basal part of the maxillule, and the formulas $1,1, \mathrm{I}, 3$ and $1,1, \mathrm{I}, 2$ for the third segment of the endopod of legs 3 and 4 , respectively.

In some respects, the new species approaches the monotypic Monocheres mauritianus Stock, 1966, associated with the coral Pocillopora damicornis (L.) in Mauritius. In Monocher. es, however, the tubiform siphon is long, reaching to the anterior margin of the genital double-somite, and leg 5 is very reduced, having no free segment and represented only by a row of denticles and a long plumose seta (Stock, 1966).

\section{Distribution of copepods associated with the coral Galaxea}

The Indo-Pacific genus Galaxea ranges from the eastern coast of Africa and the Red Sea to southern Japan and northern Australia to the Tuamotus (Veron, 1986). Colonies of this coral may be very large, exceeding $5 \mathrm{~m}$ in diameter, and often dominate inshore fringing reefs. Copepods associated with Galaxea (Table 1) have been found at relatively few locations, as dictated by opportunistic collections. Among the species of Galaxea thusfar examined, G. fascicularis has 13 copepod associates, G. clavus one, and Galaxea sp. one. Several species of copepods may occur with the same colony of Galaxea, as in the case of 10 different copepods found with a portion of a colony of $G$. fascicularis at Karang Mie, Halmahera. Whether these copepods have selective microhabitats on or in the coral polyps is unknown.

\section{Acknowledgements}

I thank Dr. Geoffrey A. Boxshall, the Natural History Museum, London, for his helpful comments on Pterinopsyllus. The collection and study of the material from Madagascar, the Moluccas (Banda and Halmahera), and New Caledonia was made possible by grants to the author from the National Science Foundation of the United States.

\section{References}


Brady, S.G. 1880. A monograph of the free and semi-parasitic Copepoda of the British Islands. Ray Society, London, England, $1: 1-148,3: 1-83$.

Giesbrecht, W. 1890. Mittheilungen über Copepoden. 12-14. Mitt. zool. Stat. Neapel, 14: 39-82.

Herbst, H.-V. 1989. Neue marine Cyclopoida Gnathostoma (Crustacea, Copepoda) von Puerto Rico. Bijdr. Dierk., 59: 43-61.

Humes, A.G. 1973. Cyclopoid copepods (Lichomolgidae) from fungiid corals in New Caledonia. Zool. Anz., 190: 312-333.

Humes, A.G. 1978. Lichomolgid copepods (Cyclopoida) associated with fungiid corals (Scleractinia) in the Moluccas. Smithsonian Contr. Zool., 253 : 1-48.

Humes, A.G. 1979. Poecilostome copepods (Lichomolgidae) associated with the scleractinian coral Galaxea in the Moluccas. J. nat. Hist., 13: 507-528.

Humes, A.G. 1985. A review of the Xarifidae (Copepoda, Poecilostomatoida), parasites of scleractinian corals in the Indo-Pacific. Bull. mar. Sci., 36: 467-632.

Humes, A.G. 1991a. Copepoda associated with scleractinian corals on the Great Barrier Reef, northeastern Australia, with a key to the genera of the Lichomolgidae. J. nat. Hist., 25: 11711231.

Humes, A.G. 1991b. Copepoda associated with the scleractinian coral Montipora in the Indo-Pacific. Proc. biol. Soc. Wash., 104: 101-137.

Humes, A.G. 1995. New species of Anchimolgus (Copepoda: Poecilostomatoida: Lichomolgidae) associated with the scleractinian coral Goniopora in the southwest Pacific. J. Nat. Hist., 29: 65 -84 .

Humes, A.G. \& Boxshall, G.A. (1996). A revision of the lichomolgid complex (Copepoda: Poecilostomatoida) with the recognition of six new families. J. nat. Hist., 30: 175-227.

Humes, A.G. \& Gooding, R.U. 1964. A method for studying the external anatomy of copepods. Crustaceana, $6: 238-240$.

Humes, A.G. \& Ho, J.-S. 1968. Lichomolgid copepods (Cyclopoida) associated with corals in Madagascar. Bull. Mus. comp. Zool., 136 : 353-414.

Sars, G.O. 1913. An account of the Crustacea of Norway with short descriptions and figures of all the species. Vol. VI, Copepoda Cyclopoida, Parts I \& II Oithonidae, Cyclopinidae, Cyclopidae (part). Pp. 1-32. Bergen Museum, Bergen, Norway.

Stock, J.H. 1965. Copépodes associês aux invertébrés des côtes du Roussillon V. Cyclopoides siphonostomes spongicoles rares et nouveaux. Vie et Milieu, 16:295-324.

Stock, J.H. 1966. Cyclopoida siphonostoma from Mauritius (Crustacea, Copepoda). Beaufortia, 13: $145-194$.

Stock, J.H. 1990. A new species of Anchimolgus (Copepoda: Poecilostomatoida: Lichomolgidae) associated with an Indian corallimorpharian. Zool. Med., 63: 335-341.

Veron, J.E.N. 1986. Corals of Australia and the Indo-Pacific. Angus \& Robertson, North Ryde, Australia. $644 \mathrm{pp}$.

Wilson, M.S. 1973. Two new species of the cyclopoid copepod genus Pterinopsyllus from the Gulf of Mexico. Bull. mar. Sci., 23 : 510-520. 